\title{
Prison Labor: The Price of Prisons and the Lasting Effects of Incarceration*
}

\author{
Belinda Archibong ${ }^{\dagger}$ \\ Barnard College
}

\author{
Nonso Obikili $\ddagger$ \\ ERSA and Stellenbosch University
}

June 25, 2020

\begin{abstract}
Institutions of justice, like prisons, can be used to serve economic and other extrajudicial interests, with lasting deleterious effects. We study the effects on incarceration when prisoners are used primarily as a source of labor using evidence from British colonial Nigeria. We digitized sixty-five years of archival records on prisons from 1920 to 1995 and provide new estimates on the value of prison labor and the effects of labor demand shocks on incarceration. We find that prison labor was economically valuable to the colonial regime, making up a significant share of colonial public works expenditure. Positive economic shocks increased incarceration rates over the colonial period. This result is reversed in the postcolonial period, where prison labor is not a notable feature of state public finance. We document a significant reduction in contemporary trust in legal institutions, like police, in areas with high historic exposure to colonial imprisonment. The resulting reduction in trust is specific to legal institutions today.
\end{abstract}

JEL classification: H5, J47, O10, O43, N37

Keywords: Prison, Taxation, Convict Labor, Public Works, Economic Shocks, Trust

*Thanks to Liz Ananat, Sandy Black, David Weiman, Alan Dye, Marlous van Waijenburg, Michiel de Haas, Denis Cogneau, Rajiv Sethi, James Fenske, Ewout Frankema, Florence Bernault, Naomi Lamoreaux, Gerald Jaynes, Suresh Naidu, Tim Guinnane, Anja Benshaul-Tolonen, Robynn Cox, Francesc Ortega and participants at the Yale Economic History seminar, the Columbia University Women in Economics seminar, the Queens College economics seminar, the Social Science History Association, the Liberal Arts Colleges Economic History workshop, African Economic History Network, African Studies Association and the American Economic Association ASSA conferences for useful comments and suggestions. Thanks to Yuusuf Caruso, Monique Harmon, Bennie Chen, Yubang Weng, Anamaria Lopez, Robrenisha Williams, Chloe Dennison, Serena Lewis and others for excellent research assistance. All errors are our own.

${ }^{\dagger}$ Corresponding author. Barnard College, Columbia University. 3009 Broadway, New York, NY 10027, USA. ba2207@columbia.edu.

${ }_{\ddagger}^{\ddagger}$ Economic Research Southern Africa (ERSA) and Stellenbosch University. me@nonsoobikili.com. 


\section{Introduction}

"The Prison at Port Harcourt has been considerably developed and at the close of the year there were 829 prisoners in custody and these are employed by the Eastern Railway. The Engineer in charge at Port Harcourt is highly pleased with the way the prisoners are worked; they have given no trouble and have been of great assistance in developing that station. It was my intention to have 1,000 prisoners stationed there before the close of the year, but this was impossible as two prisons... which should have supplied the drafts to make up the number, had an outbreak of chicken-pox..."

- E. Jackson, Acting Inspector of Prisons, Lagos, 23rd April, 1915

There are more people incarcerated today than at any other point in human history ${ }^{1}$. The current prison population is estimated at around 11 million people globally, and with trends of rising incarceration around the world, the policy discussion has turned to what to do with the large reserve of incarcerated people (Jacobson, Heard, and Fair, 2017). One suggestion that has risen to prominence in recent years in countries like the United States and China, is to use prisoners for labor- for work on everything from manufacturing and public works projects to fighting fires and making hand sanitizer to combat pandemics (Campbell, 2020; Chapman, 2019; Doston and Vanfleet, 2014). Despite the fact that in the US alone ${ }^{2}$, prison labor contributes to a lower bound estimate of $\$ 2$ billion a year in industrial output $^{3}$, there is almost no economics research examining the moral hazard issues that might

\footnotetext{
${ }^{1}$ Sources: World Prison Brief and Prison Policy Initiative

${ }^{2}$ The United States has been a particularly heated center of the debate around prison labor since it holds the title of the country with the highest incarceration rate globally; around $0.7 \%$ of the US population was incarcerated as of 2019, and the US has over $20 \%$ of the world's prison population with just $5 \%$ of global overall population. Source: World Prison Brief.

${ }^{3}$ Estimates as of 2004. Sources: Prison Policy Initiative and Bair (2007). There are almost no quantitative estimates on the value of goods produced by prison labor in the Untied States.
} 
arise when prisoners are viewed primarily as a reserve of labor by governments. What are the effects on incarceration when prisoners are viewed and used as a source of labor to serve economic interests? And what are the potential implications for citizens' views of state legitimacy, when an institution of state justice, like prisons, is used to serve economic interests?

We answer these questions using evidence from colonial Nigeria over 1920 to $1959^{4}$, where prison labor was a feature of state public finance and the labor market; and from post-colonial Nigeria over 1971 to 1995, when prison labor was not a major feature of state finance. We construct a novel dataset from 65 years of archival records on prisons from 1920 to 1995. We assembled data on prisons, wages, prices and colonial public finance from colonial and postcolonial archives, along with geocoded climate information from high resolution NASA data to test our hypotheses.

The aim of this paper is to examine how incarceration responds to economic shocks when prison labor is a major feature of state policy and public finance. To investigate this topic, we conduct our analysis in 3 steps. First, we assess the importance of prison labor by first calculating the value of unpaid prison labor and then estimating the share of prison labor in colonial public finance. A key insight from the historical archives is that, as part of explicit colonial policy, prison labor on government public works was a mandated part of incarceration ${ }^{5}$. Unpaid prison labor was an essential input in the construction and maintenance of key revenue-generating public works like the railroad, used to transport agricultural commodities for export. We provide the first, to our knowledge, set of estimates of the value of unpaid prison labor in British colonial Africa. We measure the overall value of prison labor as the amount of unpaid wages to prison laborers.

\footnotetext{
${ }^{4}$ Nigeria as an amalgamated entity was a British colony from 1914 to 1960, so our dataset covers almost 40 of the 47 years of the colonial period. The country was under military rule for most of 1960 to 1999, before transitioning to democracy in 1999.

${ }^{5}$ The 1916 Prison Ordinance outlined the use of convict labor explicitly (Kingdon, 1923).
} 
We find that prison labor was economically valuable to the colonial regime. The overall, gross value of prison labor is strictly positive over the entire colonial period. Even after accounting for the most expansive set of prisoner maintenance costs, the net value of prison labor is nonnegative and strictly positive in $60 \%$ and $57 \%$ respectively of the years from 1920 to 1959 in Nigeria. Prison labor made up a significant share of colonial public works expenditure. The share of overall prison labor in colonial public works expenditure ranged between $40 \%$ and $249 \%$, with an average of $101 \%$ over 1920 to 1959 . After adjusting for extensive measures of prisoner maintenance costs, the share of overall prison labor in colonial public works expenditure remains economically significant with a mean of $5 \%$ and a maximum of up to $42 \%$ during this period.

Having established the value of convict labor for the colonial regime, next, we assess the effects of shocks to economic productivity on incarceration and the use of prison labor using a panel regression framework. We construct two measures of shocks to economic productivity. The first measure exploits district level rainfall deviations in a primarily agricultural setting. The second measure uses agricultural commodity prices and district level crop suitability. We show that incarceration rates are procyclical during the colonial period. Positive economic shocks increase colonial incarceration rates and the use of prison labor. The positive effect is specific to short-term incarceration rates only, with temporary shocks increasing the share of prisoners with sentences less than 6 months. There is no effect of positive shocks on long-term imprisonment or the share of prisoners with sentences greater than 2 years. In one specification, moderate positive rainfall shocks that raise agricultural productivity increase short-term incarceration rates by 16.7 prisoners per 100,000 population, a $12 \%$ increase relative to a mean of 134.7 prisoners per 100,000 population. This effect is reversed in the postcolonial period where prison labor is not a main feature of state policy and negative productivity shocks like droughts increase incarceration rates. Using an index of export crop prices, we also show that a $1 \%$ increase in export prices for a major cash crop in producing 
regions is associated with a $2 \%$ increase in short-term incarceration relative to the sample mean.

We provide evidence from the historical literature and show that a primary reason for the procyclical behavior of incarceration rates during the colonial period was increased labor demand for construction and maintenance of public works like railroads, needed to intensify exports of agricultural commodities during periods of positive productivity shocks. Labor shortages and tight labor markets, worsened by wage ceilings in the government public works sector, increased the demand for unpaid prison labor, in line with predictions from theoretical models of labor coercion (Acemoglu and Wolitzky, 2011). One way colonial authorities addressed these labor shortages was to increase the share of incarcerated people by, for example, switching the punishment of certain crimes from fines to imprisonment (Killingray, 1999). We test the tight labor market hypothesis by examining the effects of rising wages on incarceration rates by distance to the colonial railroad. The results show that while prisons closer to the railroad have higher short-term incarceration rates, higher wages increase the share of short-term prisoners from prisons farther away from the railroad. The quantitative estimates support historical accounts of prisoners being transported from prisons throughout districts to work on railroad and other colonial public works projects during periods of labor shortages (Killingray, 1999).

Finally, to explore the implications of colonial use of prison labor for present day views of state judicial legitimacy, we present a brief discussion and suggestive evidence of the longrun effects of colonial incarceration on contemporary trust in legal institutions. Given that the origins of the modern prison and accompanying legal system in Nigeria and other former British colonies are rooted in the use of state policy around labor coercion, what are the long-term effects, if any, of exposure to these systems on citizens' trust in these institutions today? We use Afrobarometer data from Nigeria on trust in historical legal institutions 
(e.g. police, courts, tax administration) and trust in individuals (e.g. neighbors, relatives, president) to test whether past exposure to coercive, ostensibly economically influenced colonial prison structures is associated with trust in legal institutions today. We document a significant reduction in contemporary trust in legal institutions, and police in particular, in areas with high historic exposure to colonial imprisonment. The resulting reduction in trust is specific to legal institutions, with no effect of colonial imprisonment on interpersonal, trust in individuals.

Colonial Nigeria presents an excellent region to study these issues, with generalizable lessons for many jurisdictions today, for a number of reasons. First, colonial Nigeria had relatively high incarceration rates. As of 1940, the British colonial government in Nigeria was incarcerating more people (.3-.4\% in 1940) than countries in Europe over a similar period $(.06 \% \text { in } 1950)^{6}$. In fact, colonial Nigeria was incarcerating about the same fraction of people as the notoriously racially unequal US prison system was incarcerating its Black population over the same time period, and at a higher rate than the overall US incarceration average of less than $.2 \%^{7}$. To put these figures in context with contemporary data, Figure 1 shows the top 40 of 222 countries/jurisdictions by incarceration rate in the world as of 2018. If we place colonial Nigeria's incarceration rates in 1940 on the chart, it would have ranked at number 15 of 222 in the world today right between Seychelles and Panama, as shown in the figure. Nigeria incarcerates a much lower share of people today, ranking at around 211 of 222 by World Prison Brief estimates.

We add to several distinct literatures. First, we add to the literature on the economics of forced labor and coercive labor contracts (Acemoglu and Wolitzky, 2011; Bobonis and Morrow, 2014; Dell, 2010; Gregory and Lazarev, 2013; Juif and Frankema, 2018; Lowes and

\footnotetext{
${ }^{6}$ Source: Author estimates from archival data and World Prison Brief.

${ }^{7}$ Colonial Nigeria at a rate of between .2-.4\% on average compared to the US Black incarceration rate of around $.4 \%$ over the same period. Source: (Muller, 2012).
} 
Montero, 2016; Naidu and Yuchtman, 2013; van Waijenburg, 2018; Saleh, 2019). Previous work has examined the impacts of economic shocks on coercive contract enforcement (Naidu and Yuchtman, 2013), and estimated the share of forced labor in colonial public finance (van Waijenburg, 2018), but there is very little evidence on the economics of prison labor, with most of the research on prison labor concentrated on the United States (Poyker, 2019; Travis, Western, and Redburn, 2014; Cox, 2010) and the Soviet Union (Gregory and Lazarev, 2013). We also add to the literature on the economics of incarceration (Becker, 1968; Avio, 1998; Katz, Levitt, and Shustorovich, 2003). While previous work has focused on the effects of crime and prison conditions on incarceration rates and recidivism (Becker, 1968; Freeman, 1999; Bhuller et al., 2020; Katz, Levitt, and Shustorovich, 2003), here we highlight the role of economic shocks in increasing incarceration under coercive state institutions.

There is almost no social science research providing quantitative estimates on the economics of prison labor. Of the 95,916 articles on prison labor in the scholarly archive Jstor, just $4 \%$ are classified in 'economics' journals. And of those, only 2 papers provide quantitative estimates on the value and economic drivers of prison labor, with research focused on estimating the value of British convict labor in 18th century America (Grubb, 2000, 2001). Although there is a robust qualitative literature in history, political science and sociology on convict labor, previous efforts at providing quantitative estimates of the economic drivers of prison labor have been stymied by the paucity of detailed, micro-level data on incarceration and the value of prison labor. Our paper is the first, to our knowledge, to provide quantitative estimates on both the value of prison labor and the effects of economic shocks on the use of prison labor, particularly when convict labor is a major part of state policy and public finance, using evidence from extensive archival data.

While previous work has examined the impacts of institutions like the slave trade (Nunn, 2008) and labor concessions (Dell, 2010; Lowes and Montero, 2016) on development 
outcomes, interpersonal trust (Nunn and Wantchekon, 2011) and trust in modern medicine (Lowes and Montero, 2018), our paper is the first, to our knowledge, to explore the long-term effects of prison labor systems on trust in legal institutions, like police, and views of state legitimacy. Given the discussion in the United States and around the world on the effects of incarceration on views of state legitimacy, for example around the relationship between the high historic racial gap in incarceration between Black and White populations in the US and the Black-white racial gap in trust in legal institutions like the police (Sherman, 2015), it is important to understand how systems of prison labor may affect trust in legal institutions. This is needed, particularly in light of research linking environments of low trust in legal institutions and low views of state legitimacy with conflict (Rohner, Thoenig, and Zilibotti, 2013), low domestic investment and higher transaction costs from weak contract enforcement (Knack and Keefer, 1997), and issues with effective policing, crime and law enforcement (O’Flaherty and Sethi, 2019).

The paper is organized as follows: Section 2 provides historical background on prison labor in colonial Africa. Section 3 reports quantitative estimates of the value of prison labor to the colonial regime. Section 4 describes the data on prison labor and economic shocks and presents the results on the effects of economic shocks on incarceration rates and the use of prison labor. Section 5 discusses the links between colonial imprisonment and contemporary trust in legal institutions. Section 6 concludes.

\section{Prison Labor in Colonial Africa}

\subsection{A History of Forced Labor}

Prison labor was a small part of a larger regime of domestic forced labor in colonial Africa. European colonial governments were tasked with pursuing strategies to maximize revenue extraction while minimizing costs of administration in Africa (Gardner, 2012). Attempts 
to raise revenue to fund expenditures on key public works projects like roads and railroads necessary for both revenue extraction from cash crop exports and expansion of control of colonies, rested crucially on the colonial government's ability to raise revenue through direct or indirect taxation and cut costs associated with expenditures. Labor shortages were an endemic feature of the African colonies (Okia, 2012; Ash, 2006). Shortages were driven partly by an unattractive wage labor market for government projects, which itself was partly spurred by artificially imposed below-market wage compensation, set both as a cost-cutting measure and to prevent competition with the private sector, and to satisfy the economic and political demands of white settler employers (Okia, 2012; Maul, 2007; Ofonagoro, 1982).

To address these constraints, colonial governments enacted a series of strategies to meet labor and revenue demands. Among these strategies included the use of direct taxation like hut and poll taxes requiring cash payment to press Africans into the wage labor market, the use of labor tax legislation to force Africans to donate a certain number of hours of often unpaid labor to private and public sector work, and the use of precolonial communal labor requirements to compel Africans, under the direction of the chiefs, to provide unpaid labor for private and public works projects (Okia, 2012; Harris, 1914; Trevor, 1936; van Waijenburg, 2018; Cooper, 1996).

Forced labor was recognized by the colonial regime as so essential to the functioning of the state, that in one instance, when the colonial office in Nigeria surveyed commissioners in 1911 on their preferences for terminating the House Rule Ordinance which bolstered the authority of chiefs to coerce labor for the government, the minutes from the meeting report that "Perhaps most interesting evidence of all is that of the Commissioners who with one lament ask how is the administration to be carried out if we cannot go to the Head of a House and demand carriers and paddlers? How is the work of sanitation, road making and clearing to be carried on if we cannot hold the Head of the House responsible for finishing 
the necessary labour? They are all of the opinion that the necessary labour cannot be got, even at a ruinous price, and that thus the progress and development of the country would be retarded." (Ofonagoro, 1982), p. $213^{8}$. Another important source of forced labor was convicts.

\subsection{Prison Labor in Colonial Africa}

Two main reasons for the use of prison labor emerge in the historical literature. First, prisoners were employed to work as punishment for crimes, as defined by regimes, and second, mostly unpaid prison labor was viewed as a source of cheap labor particularly for industrial projects in the colonies (Adamson, 1984).

Similar crimes did not correspond to similar punishment, a fact which was often exploited by European colonial governments to address fiscal pressures and labor shortages (Branch, 2005). An example of this can be found in an account from British Kenya between 1895 and 1939 where Anderson (2000) outlines the ways in which a combination of labor demands by the colonial government and racist views around physical punishment as a 'necessary evil' for 'civilizing' African populations, led to differential prosecution of African convicts versus their European and Asian counterparts under alleged violations of the 1906 Masters and Servants Ordinance. The Ordinance regulated employment contracts between workers and employers in the region and heavily favored private employers, most of whom were white European settlers in disputes. Among the possible punishments for violations of the ordinance, which included 'desertion' from work without prior notice, "absence during work hours", "careless or improper work" and "using insulting language to the master", were fines, prison time extending up to 6 months and whipping (Anderson, 2000), p. 462. Europeans and Asians convicted for breach of the Masters and Servants Ordinance were much

\footnotetext{
${ }^{8}$ Ward-Price, op. cit., p.213. See also CO/520/107, 'Native House Rule Ordinance', minutes by Sir Percy Anderson, 18/12/1911.
} 
more likely to get fines than prison time or whipping, with Africans more than three times likely to get prison time than their European counterparts and the only group to be whipped as punishment between 1931 and 1938 as shown in Figure 2.

\subsection{Prison Labor in British Colonial Nigeria}

In British colonial Nigeria, which lasted formally from 1914 to 1960, and throughout its African colonies, labor taxes and labor laws worked in concert with Masters and Servants Ordinances, vagrancy laws, labor registration, pass laws and Native Authority Ordinances that mandated the conscription of African laborers to work on colonial public works projects (Hynd, 2015). Though there is limited disaggregated data on the types of crimes individuals were convicted of, available data from colonial records in Nigeria show that over $50 \%$ of total convictions in colonial courts were from "offences against revenue laws, municipal, road and other laws relating to social economy of the colony" between 1920 and 1937 as shown in Figure $3^{9}$. The colonial regime was highly dependent on revenue from agricultural commodity exports as shown in Figure $4^{10}$ and relied on domestic labor in facilitating production and exports.

Alongside the growth of coercive laws in the colonies, was the increased use of the prison system and convict labor to work on government public works projects, particularly in the early part of the 20th century (Hynd, 2015; Akurang-Parry, 2000; Abiodun, 2017; Bernault, 2007). Individuals who refused or were unable to pay direct or labor taxes or the fines associated with non-payment, or committed petty crimes against the colonial regime or their Native Authorities, were arrested and placed in prison, after which their labor was subsequently used to work on colonial public works projects. An example of this is presented

\footnotetext{
${ }^{9}$ Source: British colonial Blue Books, multiple years. There is no disaggregated crime data by the categories listed in the colonial records between 1940 and 1960.

${ }^{10}$ This is reversed in the postcolonial regime when revenues from petroleum replace agricultural exports as the major source of government revenue.
} 
in accounts by Felix Ekechi (1989) and Stacey Hynd (2015) where a sizable number of the inmates in the Owerri prison in South-Eastern Nigeria were young men who had resisted mandated labor under the labor regulations, after which they were imprisoned and employed as convict labor on the Eastern Railway. In Nigeria and the Gold Coast, Roger Thomas (1973) notes that convict labor was often used to manage labor shortages in cash crop production and mining through the 1920s.

In Nigeria, as of the time of its amalgamation from two separate northern and southern provinces to a single entity under the governorship of Sir Frederick Lugard in 1914, the need for cheap labor combined with the reticence of indigenous workers to work at below market rate wages on often grueling industrial railroad, road construction and other public infrastructure projects, motivated Lugard to pass the 1916 Prisons Ordinances act giving, among other things, control of the use of prison labor to the Governor (Kingdon, 1923; Abiodun, 2017). The Prisons Ordinance along with the 1914 Native Courts Ordinance also outlined the functioning of Nigeria's dual prison system, with the colonial prisons under the management of the Director of Prisons and Native Authority Prisons overseen generally by the local chiefs ${ }^{11}$ (Kingdon, 1923). Only government agencies were permitted to use prison labor and prisoners were tasked to work within their provincial districts (Kingdon, 1923; Abiodun, 2017; Foreign and Office, 1947).

Colonial prisons served a dual mandate, functioning as centers of control of African populations, and a source of cheap labor, allowing the regime to address chronic labor shortages by providing government administrators with a steady supply of convict labor (Saleh-Hanna, 2017). So significant was the role of prison labor in the revenues and expenditures of the colonies, that in 1911, the Governor of Northern Nigeria remarked that "The value (calcu-

\footnotetext{
${ }^{11}$ There is little historical information on the functioning of the Native Authority prisons, and we use records on colonial prisons here. This means the number of prisoners presented here represent only a fraction of the total number of people imprisoned during this period. We discuss this further in Section 3.
} 
lated at $2 / 3$ of the market rate) of prisoners' labor in connection with public works, which would otherwise have had to be paid for in cash was 3,878 pounds. If calculated at the ordinary market rates the value of the prisoners' useful labor would have exceeded the entire cost of the Prison Department" (Salau, 2015), p. 323.

Following Lugard's Order in Council act on July 20, 1916, colonial prisons were classified into three types: convict prisons, with prisoners serving 2 or more years to life sentences, provincial prisons, with prisoners serving greater than 6 months and less than 2 years sentences, and divisional prisons, with prisoners serving less than or equal to 6 months sentences (Kingdon, 1923; Abiodun, 2017). Most prisoners were unskilled laborers, with $65 \%$ to $90 \%$ of them in provincial or divisional prisons, having short sentences of less than 2 years, mainly for defaulting on tax payments, and minor offenses like petty thefts (Hynd, 2015; Report, 1925). Popular departments for the use of prison labor were Railways and Harbors, Native Administration, Police, Public Health and Education, particularly for short-term prisoners (with sentences less than 2 years). A robust prison industry system including bakeries, tailoring, shoe-making, carpentry, printing and blacksmithing, among others, meant that longer term prisoners (with sentences greater than 2 years) were taught and tasked with learning a trade like carpentry, basket making, and cloth weaving to create furniture, uniforms etc which could be sold for cash returns that were remitted to the prison department's funds (Hynd, 2015; Report, 1925). They were also tasked, as part of the partly punitive, partly "reformatory" motivation of prison work, with hard labor including activities like stone breaking and stone carrying.

Short-term prisoners were tasked with activities like "road construction, street clearing, grass-cutting, wood cutting, sanitation, conservancy and farm work", with the labor of shortterm prisoners contributing significantly to public works projects like quarries in Abeokuta province, coalfields in Enugu, industries in Lagos, and the Eastern Railway extending from 
Port-Harcourt in Owerri province which used large gangs of prison labor (Abiodun, 2017; Foreign and Office, 1960). The colonial government was heavily reliant on convict labor, with many of the coal mining projects and railroad construction work in southeastern Nigeria, for example through the early to mid 20th century, staffed by prison labor (Abiodun, 2017; Foreign and Office, 1960).

The recruitment of prisoners for labor was also stated explicitly by colonial officials, as illustrated in Abiodun (2017)'s account of the response of colonial government officials to a request for increased funds for the employment of wage labor by a British sanitary inspector in 1923: "the officials asked the prison department to find ways to either increase the prison population or recruit convicts from outstation prisons to complete the tasks." ${ }^{2}$. In another example, the Inspector of Prisons, W.H. Beverley, in the 1916 Annual Report on Prisons lists two main reasons for creating categories of prisons according to prison sentence as (a) to place 'special prisons' in "townships which are on good lines of communication and afford the most suitable description of penal labour. (Abeokuta, Enugu, Lagos, and Port Harcourt, on the eastern and western lines of the Nigerian Railway, provide quarrying, industrial work, labour connected with shipping and transport, etc.)" and (b) "the ensuring, as far as possible, of an automatic and constant supply of prisoners to each class of prisons. At the end of the year, the system appeared to be working well; the long and medium sentence men were in the prisons appointed to retain them, the prison population was evenly distributed, and nowhere was there shortage of convict labour." (Foreign and Office, 1960).

Under the colonial prison labor system, unpaid prisoners were hired out to other government departments, who then remitted payment to the prison department for the use of their labor. To make the system more efficient, prisoners' labor was classified into three

\footnotetext{
${ }^{12}$ NAI, CSO 26/2 09591 Vol.1 'Lieutenant Governor Southern Province to Resident Calabar Province: Memorandum on Prison labor' 23rd April 1923.
} 
broad types: unskilled hard labor, skilled hard labor, and light labor ${ }^{13}$. Unskilled hard labor included work for which "no training was needed", with examples given including "coaling ship, grass-cutting, painting and refuse disposal". Skilled hard labor included work for which "special training was necessary" including jobs like "basket-weaving, brick-making, carpentry, clerical work, cooking, laundering, mat-making, masonry and tailoring". Light labor consisted of "easy duties suitable to the bodily or mental infirmity of the prisoner" including "cell-cleaning, lamp-trimming, sweeping and preparation of foodstuffs for cooking"' (Foreign and Office, 1960). In Nigeria's Southern Provinces, between $73 \%$ and $91 \%$ of prisoners were engaged in hard or light labor over the 1920 to 1937 period of available data ${ }^{14}$. Prisoners engaged in hard labor alone made up over $70 \%$ of convicts over the same period. The vast majority of prisoners had to work, usually on public works projects like roads, railroads, building construction and in the mines ${ }^{15}$.

This use of prison labor for colonial public works projects continued through the 1950s in British colonial Africa with an estimated between 1 in 300 and 1 in 500 Africans imprisoned over 1930 through the 1950s, in contrast with 1 in 2000 British natives in Britain (Hynd, 2015). The practice of prison labor in Nigeria continued sporadically through the 1950s, and ended prior to Nigeria's independence in 1960 with increasing protest from local anti-colonial groups and labor unions (Killingray, 1999; Abiodun, 2017). Section A.2 in the Appendix provides more detail on the history of prison labor in British colonial Africa.

\footnotetext{
${ }^{13}$ Source: British Blue Books, Nigeria, multiple years. Other similar classifications included "industrial labor, domestic labor and unskilled labor", where 'domestic labor' was considered light labor and industrial and unskilled labor were considered hard labor.

${ }^{14}$ Between $9 \%$ and $26 \%$ of prisoners were considered 'unfit' for work either due to being non-sentenced debtors or other not yet sentenced individuals in custody awaiting trial or being too sick to work. Source: British Blue Books, Nigeria, multiple years.

${ }^{15}$ Source: British Blue Books, Nigeria, multiple years.
} 


\section{Estimating the Value of Prison Labor}

\subsection{Historical Data}

To assess the significance of unpaid prison labor for colonial public works expenditures or the value of prison labor, we digitized archival records on the prison population, wages, public works expenditure and revenue from the British colonial Blue Books and Annual Report on the Administration of the Prisons Department ${ }^{16}$ between 1920 and 1959. The Blue Books were statistical returns that governors of British dependencies were required to submit on an annual basis and report a complete record of prisons and colonial public finance between 1920 and 1938 in Nigeria ${ }^{17}$. The Blue Books and the Annual Report also include qualitative descriptions of the activities undertaken by prison departments, as reported by the Director of Prisons. An example of the archival data is shown in Figure 5. These data sources and the variables we use in our analysis are described in detail in Appendix A.1.

Figure 6 shows maps of Nigeria with its colonial provinces, regions and prison locations labeled, including the extent of the colonial railroad. We note an important point here: the colonial prisons data represent only a fraction of the overall prison population in Nigeria. We lack detailed data on Native Prisons administered by local chiefs in the colonial archives prior to 1940. Available data on Native prisons in the Annual Reports from 1940 show that the addition of Native prison estimates to the colonial estimates presented in this paper would almost double the incarceration rate in 1940 from around 224 per 100,000 population to 399 per 100,000 population. This suggests that the data we present here from 1920 to 1959 may be an underestimate of the total level of incarceration during this period. There

\footnotetext{
${ }^{16}$ Referred to as the Annual Report subsequently.

${ }^{17}$ Nigeria is amalgamated from separate regions into a single country in 1914 and although the Blue Books data extend back to 1914, some information is missing between 1914 and 1920, so we start our analysis in 1920 for completeness. The Blue Books data on prisons and public finance ends in 1938. For prison data after 1938, we use records from the Annual Report on the Administration of the Prisons Department.
} 
are also clear differences in the distribution of colonial prisons by region. Of the 48 prisons recorded in 1938, about $90 \%$ are located in the southern provinces. The map is reversed for Native prisons, with just $13 \%$ of Native prisons, 9 of 65 recorded in 1940, located in the southern provinces as shown in Figure A3 in the Appendix. Historical differences in the level of precolonial state bureaucracy drive differences in the geographical distribution of Native vs colonial prisons (Archibong, 2019) ${ }^{18}$. Using the available data from colonial prisons, we present results here as lower bound estimates on the total value of convict labor over this period.

\subsection{Empirical Strategy}

We measure the value of convict labor to the colonial regime by adapting the strategy from van Waijenburg (2018) to estimate the value of unpaid prison labor and its relative share in colonial public works expenditure. In essence we ask, 'how much would the colonial state have had to pay if they had to hire non-remunerated prison workers for a market rate wage?'

We calculate the overall value of unpaid prison labor in each year $t$ as:

$$
\text { Value of prison } \text { labor }_{t}=\text { Annual wages }_{t} \times \sum_{n=1}^{N} \text { Prisoners }_{n t}
$$

This gives us an overall, gross value of benefits accruing to government consumers of prison labor. As a measure of wages, we use the average annual market wages paid to unskilled laborers. This captures the wages for some of the types of work that prisoners were required to perform, including felling trees and breaking rocks to clear areas for road and railroad construction as discussed in Section 2. Prisoner $s_{n t}$ is the daily average number of people in prisons over $n$ days in the year from the archival records. This measure captures

\footnotetext{
${ }^{18}$ Appendix A.3 presents a brief discussion of the historical drivers behind these differences. See Archibong (2019) for a more in-depth discussion.
} 
the amount of convict labor that was available on any given day. To estimate the relative value of prison labor, we divide the results from Equation 1 by public works expenditures, prison expenditures and overall expenditure figures from the Blue Books.

The specification in Equation 1 does not factor in the costs of prisoner maintenance, including food, clothing and prison staff salaries. The archival data reports 2 sets of costs for prison maintenance: (i) food costs, which is reported as the main cost of prisoner upkeep and (ii) total prisoner maintenance costs, an estimate that divides all expenses involved in operating the prison (i.e. everything from staff salaries to equipment purchases) by the total number of prisoners in a given year. Food costs account for an average of 35\% of total prisoner costs between 1920-1959, with food costs ranging from $27 \%$ to $51 \%$ of total costs over the study period. Food costs and staff salaries make up over $50 \%$ of the total prisoner costs from 1920 to 1959. The total prisoner maintenance cost category is the most expansive measure of prison upkeep costs. We present results on the net value of prison labor using both the food costs and the total prison maintenance costs in Section 3.3.

Figure 7(a) shows the trends in the reported average annual wages and prisoner food and overall maintenance costs. The total reported prisoner upkeep costs closely tracks the wage, reflecting increases in staff salaries over time, with a steep increase after 1940. Prisoner food costs follows a similar pattern, though the post-1940 increase in costs is less steep than the wage and total prisoner costs. Figure $7 \mathrm{~b}$ shows the daily average number in prison over the study period. The wage is above prisoner food costs in all years, and above total prisoner costs in over $51 \%$ of the years between 1920 and 1959. The daily average numbers in prison fluctuate notably between 1920 and 1940, increasing through 1930, then decreasing between 1930 and 1940 before sharply increasing after 1943. Interestingly, the daily average numbers in prison also appear to track the average annual wage figures in Figure 7a.

We estimate various versions of Equation 1 in alternate specifications, including esti- 
mates using alternate wage measures, adjusting for inflation and addressing potential bias in prisoner estimates by computing a weighted average measure of people committed to prison for penal imprisonment in each year. The trends in the results remain unchanged and are detailed in Appendix A.4.

\subsection{Value of Prison Labor Results}

Figure 8(a) and Table A2 in Appendix A.4 report our imputed total and net value of prison labor results. The total, gross value of prison labor starts out around 178,498 pounds in 1920 and fluctuates, first decreasing, then increasing through 1927, before mostly declining through 1943, then increasing sharply afterwards, peaking at 1,532,634 pounds in $1959^{19}$. The average gross value of prison labor is 313,742 pounds over the colonial period. We observe similar trends with the net value of prison labor figures, less prisoner food costs; the net value of prison labor less food costs remains strictly positive over the study period with the average falling to 195,260 pounds. When we estimate the net value of prison labor using the most expansive measure of prisoner maintenance costs reported, the mean falls further to 31,674 pounds. The net value of prison labor using total reported prisoner maintenance is nonnegative and strictly positive in $60 \%$ and $57 \%$ respectively of the colonial period in Nigeria.

To evaluate the significance of the prison labor value for colonial public finance and spending on public works, the major category prison labor was employed on, in particular, we estimate the ratio of our prison labor values to reported public works expenditure. We also compare the prison labor values to overall prison expenditure and overall expenditure by the colonial government. Figure 8(b) and Table A2 report the estimates for the share of prison labor in public works expenditure from 1920 to 1959. The share, using the gross value

\footnotetext{
${ }^{19}$ Given the debates around the choice of the price index for colonial Africa, we present the figures in nominal terms here (Frankema and Van Waijenburg, 2012). We present the real estimates in Appendix A.4. The trends remain unchanged.
} 
of labor coercion, fluctuates throughout the colonial period; it starts out at $133 \%$ in 1920 , then declines through 1932, before increasing through 1936 and declining through the 1940s. The prison labor share in public works expenditure increases sharply post 1943, peaking in 1952 and 1953 at $249 \%$ before declining through 1959. The share of overall prison labor in colonial public works expenditure ranged between $40 \%$ and $249 \%$, with an average of $101 \%$ over 1920 to 1959. After adjusting for extensive measures of prisoner maintenance costs, the share of overall prison labor in colonial public works expenditure remains economically significant with a mean of $5 \%$ and a maximum of up to $42 \%$ during this period.

We show similar trends for the prison labor share of total prison expenditures and overall colonial expenditures over this period in Figure 8(c) and Figure 8(d) respectively. Given the relatively small share of public works expenditure in overall colonial spending, prison labor shares in overall colonial expenditure are low; making up an average of $2 \%$ and $0.1 \%$ of total expenditures, using the gross and net values of prison labor (including total prisoner maintenance costs) respectively. The results show that prison labor was economically valuable to the colonial regime.

\subsubsection{Comparing Imputed Estimates of the Value of Prison Labor to Reported Colonial Estimates}

As a specification check, we compare our estimates of the value of prison labor to the colonial government's own estimates of the value of prison labor, shown in Figure 8(a) and Table A2. In some years, the colonial authorities published their own estimates of the total value of prison labor in Nigeria. Prisoners were most often hired to the Public Works and other government agencies for labor. Although the prisoners themselves were not paid, payment was remitted directly from these agencies to the Prisons department for prisoners' work. The prison department then had to set prices for their prisoners' work for other government agencies. These prices are explicitly listed as their estimates of the 'value of prison labor' in 
the Annual Reports ${ }^{20}$.

We compiled these estimates where available, and they provide us with comparable data from 1919 to 1925 . Figure 9 shows our estimates of the difference in the daily market wage rate versus the prison rate in the Lagos colony and southern provinces for laborers or unskilled hard labor and for carpenters and joiners and bricklayers and masons, two classes of skilled hard labor. Lacking data past 1921 on the per diem prison rates, we assume, based on the past record, that the rates remain stable through 1925. As shown in Figure 9, prisoners performing unskilled hard labor, which made up the majority of the prison population (prisoners with shorter-term sentences), were assigned a value between about $60 \%$ to $80 \%$ below the market wage rate over 1919 to $1925^{21}$. Our measures of the value of prison labor are higher than the estimates of the colonial authorities; colonial prison officials were consistently undervaluing prisoners' labor to keep costs of administration for their peer departments low while attempting to balance their budgets.

\footnotetext{
${ }^{20}$ The Directors of Prisons, for example, W.H. Beverly, E. Jackson or W. Reeder in the southern provinces over 1915 to 1921, recorded per diem estimates of the value of labor between 1916 and 1921 in the Lagos colony and southern provinces for Nigeria. Using the classification of labor into skilled hard labor, unskilled hard labor and light labor, described in Section 2.3, hard labor, both unskilled and skilled are given a value of 5 pence per day, with light labor given a value of 3 pence per day in 1916. Starting in 1917, skilled hard labor is given a value of 1 shilling and 6 pence or 18 pence, unskilled hard labor is assigned a value of 5 pence and light labor is assigned a value of 3 pence. The rates for unskilled hard labor stay the same from 1918 through 1921, with no reporting on the exact value assigned to skilled hard labor or light labor over this time. After 1921, the reports stop including information on the per diem value assigned to the different classes of labor.

${ }^{21}$ This confirms the report written by Beverley himself in the 1915 Annual Report on Prisons where he states that values assigned to prisoners' labor is below "wages demanded by workmen in civil life". He recommends a doubling of values to balance prison expenditure amounts, illustrating the balance sheet calculus that appeared to drive the setting of values of prison labor.
} 


\section{The Effects of Economic Shocks on Incarceration Rates and the Use of Prison Labor}

\subsection{Data on Incarceration Rates and Economic Shocks}

Given the economic significance of prison labor for colonial public works shown in Section 3 , to understand the effects of economic conditions on the use of prison labor, we examine the effects of economic shocks on incarceration rates over the colonial period. Our outcome, incarceration rates, are only available in disaggregated form during the colonial period from 1920 to 1938, and we limit our analysis to these years for the colonial era. The Blue Books reports imprisonment data at the prison level, and we aggregate up to the district level, where district is the colonial province between 1920-1938, and calculate incarceration rates as the number of newly admitted prisoners per 100,000 population for each province in each year.

The imprisonment data is broken down by length of prison sentence, classified as shortterm (less than 6 months), medium-term (between 6 months and 2 years) and long-term (greater than 2 years) prisoners. We use this classification of sentences for falsification tests, to test the hypothesis that yearly variation in economic shocks should affect short-term prisoners whose populations are more elastic than long-term prisoners. As an additional falsification test, and to test the hypothesis presented in Section 1 and Section 2 that the impacts of shocks on incarceration should differ between the colonial and postcolonial period due to differences in the economic structure and state policy regarding incarceration between the two periods, we use available data on postcolonial incarceration rates at the current administrative state level between 1971 and 1995 from Nigeria's Annual Abstract of Statistics $^{22}$.

\footnotetext{
${ }^{22}$ The postcolonial data does not include breakdown by sentence.
} 
To measure economic shocks, and test the hypothesis presented in the introduction that positive shocks will increase incarceration rates under a regime that uses prison labor to serve economic interests, we use two sets of data. Since our setting is primarily agricultural ${ }^{23}$, we can measure shocks to economic productivity using data on rainfall and agricultural commodity export prices. First, we use rainfall data from 69 weather stations recorded in the Blue Books to construct measures of rainfall deviations or z-scores, as deviations from the province long-term mean. We use this to estimate the effects of rainfall shocks on incarceration rates $^{24}$. For our falsification test in the post-colonial period, we use precipitation data from the National Aeronautics and Space Administration (NASA) MERRA-2 database ${ }^{25}$.

Second, we estimate the effects of productivity shocks on colonial incarceration rates using export crop price data on the major cash crop exports in colonial Nigeria, cocoa, palm oil and groundnuts, from the Wageningen University African Commodity Trade Database (ACTD) (Frankema, Williamson, and Woltjer, 2018). We combine the price data with land suitability and crop production data from the Global Agro-Ecological Zones (GAEZ) and Blue Books databases respectively to enable us to identify which prices would theoretically affect which districts.

\subsection{Summary Statistics}

Summary statistics are presented in Table 1. The average incarceration rate falls by almost a third between the colonial and postcolonial periods from around 241 prisoners per 100,000 people to 92 respectively as shown in Table 1 and Figure 10. The spatial distribution

\footnotetext{
${ }^{23}$ The share of agriculture in GDP has ranged between $40 \%$ and $60 \%$ between 1960 and 2012 by some estimates (Ahungwa, Haruna, and Abdusalam, 2014).

${ }^{24}$ In alternate specifications, we test results with interpolated data from the University of Delaware database, and confirm that while there is a significant positive correlation between the rainfall values, the correlation is low and does not translate to the z-scores which are the main explanatory variable used here. Given that the Delaware values from 1920 are less fine interpolations than the weather station data, we use the weather station data here for our main results.

${ }^{25}$ The NASA MERRA-2 data is not available prior to 1980.
} 
of incarceration between the colonial and postcolonial period also changes significantly with prisoners being clustered in the southern provinces over the colonial period, and significantly more spatial dispersion in the postcolonial period as shown in Figure 11. Incarceration rates are also higher on average in the southern provinces at 216 prisoners per 100,000 population versus 19 prisoners per 100,000 population in the northern provinces ${ }^{26}$. Trends in overall colonial incarceration rates track the trends in southern incarceration rates as shown in Figure 12.

Short-term prisoners make-up the vast majority of the colonial prison population at $58 \%$ of all newly committed prisoners and $84 \%$ of penal imprisonment on average between 1920 and 1938 as shown in Table 1 . The share of long-term prisoners in penal imprisonment is comparatively much smaller at $5 \%$ over the same period. The shares of prisoners with previous convictions are similarly low, with $11 \%$ of prisoners having 1 previous conviction and only $2 \%$ of prisoners with 2 or 3 previous convictions.

Figure 13 shows the spatial distribution of cash crop production over the colonial period. Palm oil and cocoa are produced in the southern provinces, while groundnut is the major cash crop export produced in the Northern Provinces. The time series of export cash crop prices are shown in Figure 12. Prices remain relatively stable, after an initial decline in 1920, through 1930, before there is a sharp Depression-era drop in export prices through 1935. Prices start to rise again briefly before another decline towards the end of the 1938 period.

\footnotetext{
${ }^{26}$ Although we do not have detailed data on Native prisons, data provided from the colonial archives for 2 years, 1940 and 1945, show similar north-south trends in Native incarceration rates as shown in Figure A4 in Appendix A.3. From Figure A4, incarceration rates are higher in a southern province, Oyo, than in the northern provinces on average. The southern Native prisons, for the available data in the 1940s, also incarcerate more people than their northern counterparts on average, following the trends in the colonial incarceration data. Average incarceration rates in Native prisons between 1940 and 1945 (181 per 100,000 population) are slightly higher than in colonial prisons (130 per 100,000 population) over the same period.
} 


\subsection{Estimating Equations}

To examine the effects of shocks to economic productivity on incarceration rates and the use of prison labor in the colonial period, we use three estimating equations as follows: (1) a nonlinear, quadratic specification, that allows the effect of rainfall shocks on incarceration to vary more flexibly with the level of district level rainfall deviation and estimates the effects of positive productivity shocks on incarceration rates; (2) a linear specification that identifies the impacts of moderate positive rainfall shocks, in particular, on incarceration, and (3) a linear specification that identifies the effects of productivity shocks with an interaction term for agricultural export commodity prices. We include district (province or current state for colonial or postcolonial data respectively) and year fixed effects in all specifications, along with clustered standard errors at the district level. Following Cameron, Gelbach, and Miller (2008), we apply wild bootstrap-based tests to our estimates to account for potentially low numbers of clusters in estimating our standard errors and include wild cluster bootstrap p-values in our results. The rationale behind each empirical strategy is discussed in further detail in the proceeding sections. Our main specifications will be related models (1) and (2), though we interpret the results from all 3 models in Section 4.4.

\subsubsection{Nonlinear Effects of Economic Shocks on Incarceration Rates}

Following the discussion in Section 1 and Section 2, positive rainfall and agricultural commodity price shocks that boost economic productivity may increase incarceration rates by increasing prison labor demand for construction and maintenance of public works like rail-

roads, needed to intensify exports of agricultural commodities during periods of positive productivity shocks

Colonial officials push forward construction and intensify maintenance on public works like the railroad, but facing severe labor shortages due to the increased relative value of 
African laborer/farmer outside options during periods of heightened agricultural productivity, switch the prosecutions/sentencing of certain crimes to short-term prison sentences to better utilize unpaid prison labor. This is partly reflected in Figure 3 showing that the majority of crimes leading to imprisonment are "crimes against the colonial economy" (e.g. tax default). Our hypotheses here are that: (a) the main functional form of the relationship between rainfall shocks and incarceration rates in the colonial period is an inverted-u. The demand for prison labor peaks during periods of moderate positive rainfall shocks which reflect increases in agricultural productivity; in contrast, extremes in rainfall deviations like droughts and floods which lower agricultural productivity lower the demand for prison labor. Additionally, as a falsification test, these effects should only hold for short-term incarceration, which is more elastic and should be more responsive to short-term economic shocks than long-term imprisonment.

A testable implication of (a) is that: (b) as a falsification test, the effect of rainfall shocks on incarceration rates be $\mathrm{u}$-shaped during the colonial period if a major motive for state incarceration was not prison labor. Under a non-convict labor motivated prison system, droughts and floods that lower agricultural productivity should increase incarceration rates through a rise in economic crimes like theft in line with past theory and evidence from the crime literature (Becker, 1968). Incidentally, "offences against property" or property theft is also the major category of prison convictions over the postcolonial period as shown in Figure 3.

The nonlinear relationship between rainfall and agricultural output has been highlighted in previous literature as well (Lesk, Rowhani, and Ramankutty, 2016; Kaur, 2019; Sarsons, 2015). We can then estimate the causal effect of rainfall shocks on incarceration rates by assessing panel regressions of the following nonlinear, quadratic form: 


$$
\text { Prisoners }_{i t}=\beta_{1} \text { RainfallDev }_{i t}+\beta_{2} \operatorname{RainfallDev}_{i t}^{2}+\mu_{i}+\delta_{t}+\epsilon_{i t}
$$

where Prisoners $s_{i t}$ is the incarceration rate or number of newly committed prisoners per 100,000 population ${ }^{27}$ in district $i$ at year t; RainfallDev $i t$ is the rainfall deviation or z-score for each district in each year relative to the district's long-term expectation ${ }^{28} ; \mu_{i}$ and $\delta_{t}$ are district and year fixed effects respectively. Errors are clustered at the district level to allow for arbitrary correlations. Our key parameter of interest is $\beta_{2}$ which should be significantly negative if hypothesis (a) above holds and positive if hypothesis (b) holds.

Given the different shares of Native to colonial prisons and prisoners in the northern (more Native, less colonial prisons) versus southern (more colonial prisons and prisoners) provinces, and the implications of those shares for how prisoners were used for prison labor as discussed in Section 2, our third hypothesis is that: (c) the positive effect of agricultural productivity enhancing rainfall shocks on incarceration rates should hold more strongly in the southern provinces than the northern provinces over the colonial period. To test hypothesis (c), we examine heterogeneity in the effects of Equation 2 by region.

\subsubsection{Identifying the Effects of Positive Rainfall Shocks on Incarceration Rates}

While Equation 2 allows us to more flexibly identify the effects of rainfall shocks on incarceration rates and the use of colonial prison labor, it does not allow us to distinguish between positive and negative rainfall and productivity shocks. Specifically, Equation 2 does not allow us to distinguish between moderate positive rainfall shocks that signal increases in agricultural productivity and extreme positive and negative shocks that signal floods and droughts respectively that can reduce productivity.

\footnotetext{
${ }^{27}$ The results remain unchanged if we standardize by the adult population only.

${ }^{28}$ We find no effects when we test the specification using lagged rainfall deviations instead following results in previous literature (Amare et al., 2018).
} 
A problem that arises when trying to distinguish positive and negative shocks, and identify moderate positive rainfall shocks from droughts and floods is that the classification is often highly dependent on the particular regional context/climate, and, as mentioned previously, the relationship between rainfall and agricultural output is often non-linear (Lesk, Rowhani, and Ramankutty, 2016; Sarsons, 2015; Kaur, 2019; Amare et al., 2018; Jensen, 2000). Additionally, while there is a robust literature on rainfall shocks and agricultural productivity in South Asia, there is relatively little research on the links between rainfall shocks and productivity in West Africa (Amare et al., 2018; Papaioannou and de Haas, 2017; Dillon, McGee, and Oseni, 2015; Jensen, 2000).

Since we do not have data on agricultural output, we adapt definitions of rainfall shocks in Africa from previous literature (Dillon, McGee, and Oseni, 2015; Amare et al., 2018; Jensen, 2000) and estimate transition points in Equation 2 from non-parametric loess models linking rainfall deviations to colonial incarceration rates. From the transition points, we distinguish between moderate positive shocks, extreme positive shocks and extreme negative shocks as follows: (a) Positive shock (M), where ' $\mathrm{M}$ ' is moderate, is an indicator equal to 1 if $0<$ RainfallDev $_{i t}<0.75$ and a proxy for increases in agricultural productivity; (b) Positive shock (E), where ' $\mathrm{E}$ ' is extreme, is an indicator equal to 1 if RainfallDev ${ }_{i t}>0.75$, and signifies floods that reduce agricultural productivity and (c) Negative shock (E), is an indicator equal to 1 if RainfallDevit $<-0.5$, and signifies droughts that also reduce agricultural productivity.

We can then directly estimate the causal effect of moderate positive rainfall shocks on incarceration rates by estimating the following linear specification:

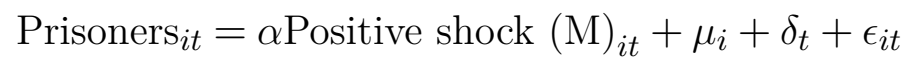


where Positive shock $(\mathrm{M})_{i t}$ is the moderate positive rainfall shock and other variables are as defined in Section 4.3.1. The main parameter of interest in Equation 3 is $\alpha$, defined as the effect of moderate positive shocks that increase agricultural productivity on the incarceration rate. In alternate specifications, we include the extreme positive and negative rainfall shock variables to check the robustness of our results. We also examine heterogeneity by southern and northern province and examine the effects of positive shocks on postcolonial incarceration rates, repeating the heterogeneity and falsification exercises in Section 4.3.1.

Though we do not have disaggregated data on crime, to test the 'sentence-switching as a way to increase the share of short-term prisoners for prison labor in response to positive economic shocks' hypothesis mentioned in Section 4.3.1, we estimate Equation 3 using the difference between custody/awaiting trial and short-term incarceration figures as an outcome. The rationale here is that, given that only sentenced prisoners could legally be used for prison labor, if there is more sentence switching from 'awaiting trial' to short-term imprisonment in response to positive economic shocks, $\alpha$ will be significantly negative for the difference.

\subsubsection{Effects of Cash Crop Price Shocks on Colonial Incarceration Rates}

As a robustness check, following the literature on commodity price shocks and agricultural productivity (Dube and Vargas, 2013; Naidu and Yuchtman, 2013), we examine the effects of plausibly exogenous agricultural export price shocks, signaling increases in agricultural productivity, on colonial incarceration rates and use of prison labor. We estimate equations of the following form:

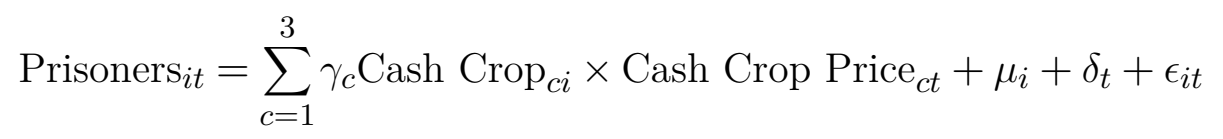

where Cash $\mathrm{Crop}_{c i}$ is an indicator that equals 1 if province $i$ produces one of the 
3 major export cash crops $\mathrm{c} \in$ (cocoa,palmoil,groundnut) over the colonial period, and Cash Crop Price $_{c t}$ is the natural log of the export price of $c$ in year $t$. The coefficient of interest is the interaction term $\gamma_{c}$ measuring the effect of increases in cash crop prices in producing provinces on incarceration rates.

The railroad was an important capital input in colonial revenue production functions, given its importance in the transport of cash crops for export (Okoye, Pongou, and Yokossi, 2019). A major use of prison labor was for public works and railroad construction and maintenance as discussed in Section 2 and shown in Section 3. As an additional specification check, we examine the effects of increases in nation-wide wages on colonial incarceration rates by distance to the railroad. The wage time series measure interacted with distance from each prison to the railroad, gives us a proxy for labor market tightness to test if a tighter labor market intensifies the demand for prison labor as reflected in colonial incarceration rates around the railroad.

\subsection{Results}

\subsubsection{Nonlinear Effects of Economic Shocks on Incarceration Rates Results}

To examine the causal effect of economic shocks on incarceration rates, we first present the results using the rainfall deviation measures in Equation 2 in Table 2. While the quadratic term is negative but not significant when we examine all penal imprisonment over the colonial period in column (1), the effect is significant and negative for short-term incarceration rates. The negative quadratic coefficient for short-term incarceration is consistent with an inverted$\mathrm{u}$ relationship between rainfall deviation and short-term imprisonment or the use of prison labor. $\beta_{2}$, the squared rainfall deviation term is not significant for medium or long-term incarceration rates, in line with the predictions in Section 4.3.1.

The results of the falsification test for postcolonial imprisonment are shown in column 
(5) of Table 2. $\beta_{2}$ from Equation 2 is positive and significant for postcolonial incarceration rates. The positive significant estimate for postcolonial incarceration is consistent with hypothesis (b) from Section 4.3.1 that the impacts of rainfall shocks on incarceration rates should be u-shaped when prison labor is not a major feature of state policy; imprisonment increases instead primarily as a response to increases in economic crimes like theft, in the aftermath of negative productivity shocks like drought or floods.

Table 3 reports the results when we examine heterogeneity by southern and northern province. $\beta_{2}$ is negative and significant for short-term imprisonment in the southern provinces, but positive and significant for northern provinces, following the discussion in Section 3. Given the relatively higher share of Native Administration prisoners in the northern provinces, one explanation for the reversal is that colonial prisons in the North contained fewer prisoners than their Native counterparts. Northerners may have been more likely to be incarcerated in colonial prisons after committing crimes that were specifically targeted against Europeans or non-African natives, like theft or violations of the aforementioned 'colonial economy' laws (Killingray, 1999; Bernault, 2007).

So while there is prison labor in both regions, the colonial prisons in the southern provinces, being the only arm of the prison system for most southern provinces ${ }^{29}$ are used more intensely for prison labor in response to labor demand shocks than their northern colonial prison counterparts. Consistent with the hypothesis that there should be no effect of yearly economic shocks on long-term prisoners, we see no effect for this category, disaggregated by region in Table 3. Consistent with the inverted u-shaped hypothesis, moderate positive rainfall shocks increase short-term imprisonment and the use of prison labor, particularly in the southern region where colonial prisons were often the only source of prison labor.

\footnotetext{
${ }^{29}$ There are 56 Native prisons in the Northern provinces vs only 9 in the South, and concentrated entirely in the southwest region as of 1940 as shown in Figure A3.
} 


\subsubsection{Identifying the Effects of Positive Rainfall Shocks on Incarceration Rates Results}

Table 4 reports the results from Equation 3 identifying the effects of moderate positive rainfall shocks that raise agricultural productivity, versus extreme positive or negative rainfall shocks, signifying floods or droughts respectively that reduce productivity on incarceration rates. The results from our main specification in column (1) show that moderate positive rainfall shocks have a significant positive effect on short-term imprisonment over the colonial period. A moderate positive rainfall shock increases the short-term incarceration rate by 16.7 per 100,000 population, or around $12 \%$ relative to the sample mean of 135 per 100,000 population. The effect remains significant, increasing short-term incarceration by about $9 \%$ when we add controls for extreme negative and positive rainfall shocks in column (3) of Table 4 .

In line with the inverted u-shape prediction, column (2) and column (3) of Table 4, shows the opposite result for extreme negative rainfall shocks which reduce short-term colonial imprisonment. Extreme negative rainfall shocks like droughts signal a decrease in agricultural productivity and decrease demand for unpaid prison labor under the colonial system; this is reflected in the lowered incarceration rates, with extreme negative rainfall shocks associated with a $13 \%$ to $15 \%$ decline in short-term incarceration relative to the sample mean. There are no effects of rainfall shocks on long-term incarceration as shown in columns (4) to (6).

In contrast, the postcolonial results show that while moderate positive rainfall shocks have no significant effect on postcolonial incarceration rates (column (7) and column (9)),

extreme negative (column (8)) and extreme positive (column (9)) rainfall shocks increase the postcolonial imprisonment rates. From column (9), the magnitude of the increase in postcolonial imprisonment from droughts/extreme negative rainfall shocks and floods/extreme 
positive rainfall shocks is a $21 \%$ and $19 \%$ increase in incarceration rates relative to a sample mean of 105 per 100,000 population. The linear specification results are consistent with the results from the quadratic specification in Equation 2 showing an inverted u-shape relationship between rainfall deviation and incarceration rates in the colonial era, with a reversal/u-shape relationship in the postcolonial period.

Table 5 reports estimates from the heterogeneity by region analysis and confirms the results from Section 4.4.1. The positive relationship between moderate positive rainfall shocks and colonial incarceration rates is driven by short-term incarceration in the southern provinces.

Table 6 provides suggestive evidence of 'sentence-switching' as a strategy to increase the share of short-term prisoners for prison labor in response to positive productivity shocks. While the specifications in columns (1) to (4) confirm a positive, mostly significant relationship between moderate positive rainfall shocks and both 'custody/awaiting trial' and shortterm incarceration rates, the effect of shocks on their difference, in columns (5) and (6), is negative. Given that the coefficients on both custody and short term incarceration rates are positive, the only way for their difference to be negative is if short-term incarceration is rising faster than custody sentences in response to moderate positive rainfall shocks. One interpretation is that people may have been transferred at a faster rate from custody/awaiting trial to short-term sentences so that the state can take advantage of their unpaid prison labor when moderate positive rainfall shocks increase labor demand and worsen labor shortages. The $\alpha$ coefficient is not robust to the inclusion of the other rainfall shock terms as shown in column (6) and should be interpreted with caution, but provides suggestive evidence of the switching hypothesis. 


\subsubsection{Effects of Cash Crop Price Shocks on Colonial Incarceration Rates Results}

Table 7 presents the results from Equation 4. The results show that the effect of plausibly exogenous positive agricultural export price shocks signaling increases in agricultural productivity on colonial incarceration rates and the use of prison labor is concentrated in crops, like palm oil, that are produced in the southern provinces. We interpret the coefficients

from the full specification of the model in column (1), with short-term incarceration rates as the outcome of interest. A $1 \%$ increase in palm oil prices in palm oil producing regions is associated with an increase in the short-term incarceration rate by around 3 per 100,000 population, a $2 \%$ increase in short-term incarceration relative to the sample mean. Shortterm incarceration rates are elastic and responsive to increases in palm oil prices signaling increases in agricultural productivity. The effect is strongest for palm oil producing regions in the south-south region where colonial prisons are the only source of unpaid prison labor, in the absence of Native prisons. There is no effect of the palm oil price interaction on long-term incarceration rates in column (5).

\subsubsection{Railroad, Wages and Incarceration Rates}

As discussed in Section 2 and shown in Section 3, a major use of prison labor was for public works and construction and maintenance of the railroad which was essential for the transport of cash crops for export. Railroad construction began in 1898 and had expanded to its full extent across the country by the 1950s as shown in Figure 6. As an additional specification check, we examine the effects of wages on colonial incarceration rates by distance to the railroad. Although we do not have data on unemployment rates, the wage time series measure interacted with distance from each prison to the railroad gives us a proxy for labor market tightness to test if a tighter labor market intensifies the demand for prison labor as reflected in colonial incarceration rates around the railroad. Table 8 reports the estimates 
for the effects of rising wages and distance to railroad on short-term incarceration rates at each prison. While short-term incarceration rates are higher in prisons closer to the railroad on average, rising wages also increase short-term imprisonment in prisons farther away from the railroad as reflected in the positive interaction in column (2).

The interpretation of the result is intuitive. While short-term prisoners near the railroad are generally used as a reserve of unpaid labor for railroad construction and maintenance, increasing wages intensify the demand for unpaid prison labor and worsen labor shortages and labor market tightness. To increase the share of prison labor, colonial officials would need to increase the share of prisoners in prisons further away from the railroad as well. They could then transport them within the province to conduct work on the railroad and associated public works as needed (Foreign and Office, 1960). In Appendix A.2, we present qualitative historical evidence from the archival material supporting this interpretation.

\section{Discussion: Colonial Imprisonment and Contemporary Trust in Legal Institutions}

To understand the implications of the colonial use of prison labor for present day views of state judicial legitimacy, we present a brief discussion and suggestive evidence of the long-run effects of colonial incarceration on contemporary trust in legal institutions. Given that the origins of the modern prison and accompanying legal system in Nigeria and other former British colonies are rooted in the use of state policy around labor coercion, what are the long-term effects, if any, of exposure to these systems on citizens' trust in these institutions today? We use Afrobarometer data from Nigeria on trust in historical legal institutions (e.g. police, courts, tax administration) and trust in individuals (e.g. neighbors, relatives,

elected local governing council members) to test whether past exposure to coercive, ostensibly economically influenced colonial prison structures affects trust in legal institutions today. 
To test the hypothesis that historical exposure to colonial imprisonment centered around prison labor may be associated with lowered contemporary trust in legal institutions, with no effect on interpersonal trust, we estimate equations of the following form:

$$
\text { Trust }_{\text {aigst }}=\beta \text { Prisoners }_{i}+\mathbf{X}_{\text {aigst }}^{\prime} \theta+\mathbf{X}_{g}^{\prime} \phi+\mu_{s}+\delta_{t}+\epsilon_{\text {aigst }}
$$

where Trust ${ }_{a s i t}$ is the contemporary trust outcome of interest for individual $a$ residing in historical colonial province $i$, in current sub-district or local government area (LGA) $g$, in state $s$ for the Afrobameter survey administered in year $t$. We include vectors of individual level covariates $\mathbf{X}_{a i g s t}^{\prime}$ and LGA level covariates $\mathbf{X}_{g}^{\prime 30}$. All regressions include state and year fixed effects. Standard errors are clustered at the district (colonial province or current state) level and wild cluster bootstrap p-values are included to account for potentially low numbers of clusters as before.

We measure Prisoners $i$ or long-term colonial imprisonment with the average of longterm colonial imprisonment over 1920 to 1938 for each province. The rationale here is that though there is a significant, high positive correlation between short-term and long-term colonial imprisonment $(.61, p<.001)$, when it comes to the long-term effects of colonial prison-labor systems, what stands out in public memory is the stock (long-term imprisonment) not the flow (short-term imprisonment) of incarceration rates. And while there is little recorded information on the determinants of long versus short-term sentences, the historical literature has documented that crimes against Europeans and colonial officials were often punished and sentenced more harshly (Abiodun, 2017; Killingray, 1999; Bernault, 2007).

So one hypothesis is that a higher share of long-term imprisonment, consisting of relatively more political prisoners, or prisoners that have committed crimes against European

\footnotetext{
${ }^{30}$ Data is described in detail in Appendix A.5.
} 
colonists, when coupled with the existing economically motivated system of convict labor, is highlighted in local memory as unjust. Exposure to long-term colonial imprisonment then reduces residents' trust in legal institutions with colonial origins like modern courts, police and systems of tax administration as a result of repeated negative experiences and long local memories as described in previous literature (Nunn and Wantchekon, 2011; Lowes and Montero, 2016, 2018). A key assumption here is that there are relatively low levels of inter-province migration, with most people residing in their provincial homelands ${ }^{31}$.

As a falsification test, we examine the effects of long-term colonial imprisonment on interpersonal trust, and hypothesize that the effects of colonial imprisonment should only be significant for trust in legal institutions, largely created during the colonial era, but not interpersonal trust which perhaps may be determined by factors before the advent of colonialism like the slave trade as shown in Nunn and Wantchekon (2011). As an additional falsification test, we examine the relationship between postcolonial imprisonment and trust outcomes, to check that the result on the negative effect of historical imprisonment on trust in legal institutions only holds for colonial imprisonment but not for postcolonial imprisonment, where prison labor was not used coercively by the state. As a final falsification test, to ensure that the associations are not being driven by differences in crime between high and low colonial imprisonment areas, we also test the following 'crime propensity' outcomes from the Afrobarometer: whether the respondent has feared being the victim of a crime in their home, and how often an individual had to bribe a government official to obtain a document or permit in the last year.

While Equation 5 includes a rich set of controls, $\beta$ does not identify the causal effect of

\footnotetext{
${ }^{31}$ Although we don't have available data on migration, previous research has shown significant positive levels of correlation between historic ethnic level residence, similar to the province level, and Afrobarometer respondent locations by ethnicity (.7 between 2008 and 2012 Afrobarometer respondents and historic c. 1850 ethnic location maps as shown in Archibong (2019)), which suggests that this assumption is reasonable in the Nigeria context.
} 
long-term colonial imprisonment on trust in legal institutions. It is possible that there is an omitted variable that determines both long-term colonial imprisonment exposure and trust in legal institutions. To address this issue, we present results using an instrumental variables approach. We construct an instrument for our colonial imprisonment outcome that is the interaction between two variables: (1) the soil suitability for palm oil and (2) an indicator that equals one if the colonial province produced palm oil. The instrument is based on the findings of the strong predictive power of palm oil production and prices for colonial imprisonment in Section 4.4.3.

To address concerns that the instrument may directly affect our trust in legal institutions outcomes through a channel other than colonial imprisonment, we include a rich set of controls alongside the qualitative evidence from the historical literature. The quantitative results and falsification tests when coupled with historical accounts of Nigerian residents' contentions about the injustices of the colonial penal system, are suggestive of the negative long-term impacts of colonial imprisonment on trust in legal institutions like police. We present further evidence from the qualitative history in Appendix A.5.

Columns (1) to (3) in Table 9 show the OLS results on the association between longterm colonial imprisonment and trust in historical legal institution outcomes, while columns (4) to (6) show the results on the association with interpersonal trust outcomes. High levels of historic long-term colonial imprisonment are significantly negatively correlated with trust in legal institutions, with no significant effect for interpersonal trust. The result does not hold for the relationship between postcolonial imprisonment and trust in legal institutions outcomes, as shown in Table A5 in the Appendix.

Panel A of Table 10 presents the first stage estimates for the instrument- using the "soil suitability for palm oil x colonial palm oil production indicator" to predict our colonial imprisonment outcome. The instrument predicts long-term colonial imprisonment, with an 
F-stat greater than 10 across all specifications. Panel B of Table 10 reports the second stage estimates our main measure of trust in legal institutions, trust in police, and one measure of interpersonal trust, trust in relatives. The IV estimates support the OLS results for some trust outcomes ${ }^{32}$. Exposure to long-term colonial imprisonment significantly decreased contemporary trust in police. There is no effect on trust in relatives.

To check that the result on the negative association between colonial imprisonment and trust in legal institutions is not being driven by underlying differences in crime rates between regions of high versus low levels of colonial imprisonment, we present results on crime in Table A6. There is no significant association between colonial imprisonment and our three crime variables as shown in columns (1) to (3). Respondents from areas with high levels of colonial imprisonment are not more likely to experience or commit crimes. Interestingly, when we examine the links between postcolonial imprisonment and crime, there is a small significant positive association with the likelihood of an individual bribing a government official to obtain a document or permit in column (4). The results provide strong, suggestive evidence of the detrimental long-run effects of colonial incarceration, centered around prison labor, on contemporary trust in legal institutions like police.

\section{Conclusion}

What are the effects on incarceration when prisoners are viewed and used as a source of labor to serve economic interests? And what are the potential implications for citizens' views of state legitimacy, when an institution of state justice, like prison, is used to serve economic interests? To answer these questions, we first digitized annual data from archival sources for British colonial Nigeria. First, we show that prison was economically valuable to the colonial regime. We present the first quantitative estimates on the value of prison labor in British

\footnotetext{
${ }^{32}$ Tables for other trust outcomes are available in Appendix A.5.
} 
colonial Africa and find that the value of prison labor is strictly positive over the colonial period. Even after accounting for an extensive set of prisoner maintenance costs, the net value of prison labor is strictly positive in the majority of years in colonial Nigeria. Prison labor made up a significant share of public works expenditures, up to $249 \%$ and $42 \%$ using our gross and net values of prison labor respectively.

We examine the effects of shocks to economic productivity on incarceration and the use of prison labor. We find that incarceration rates during the colonial period are procyclical. Moderate positive rainfall shocks and positive export price shocks that proxy increased agricultural productivity increase incarceration rates and the use of prison labor in the colonial period. We provide quantitative and qualitative evidence that to show that a primary reason for the procyclical behavior of incarceration rates during the colonial period was increased labor demand for construction and maintenance of public works like railroads, needed to intensify exports of agricultural commodities during periods of positive productivity shocks. Labor shortages and tight labor markets increased the demand for unpaid prison labor, reflected in the rise in incarceration rates. The effect is reversed in the postcolonial period where prison labor is not a major feature of state policy and public finance and negative shocks increase incarceration rates.

We explore the implications of exposure to prison labor systems for present day views of state judicial legitimacy and provide suggestive evidence of the negative long-term effects of colonial incarceration on contemporary trust in legal institutions. We document a significant reduction in contemporary trust in legal institutions like police in areas with high historical levels of colonial imprisonment. The reduction in contemporary trust is specific to legal institutions, with no effect on interpersonal trust. Historic exposure to judicial systems like prisons prioritizing economic interests over 'justice' may lower individuals' views of state legitimacy and trust in legal institutions today. Conversely, effect does not hold for exposure 
to postcolonial imprisonment. Given the renewed debates on the use of prison labor and the judicial system in countries like the US, China and globally, our paper is the first, to our knowledge, to provide quantitative estimates on the effects on incarceration when prisoners are used as a store of labor, and its potentially detrimental effects on citizens' views of state legitimacy. 
Top 40 countries, prisoners per 100,000 population, 2018

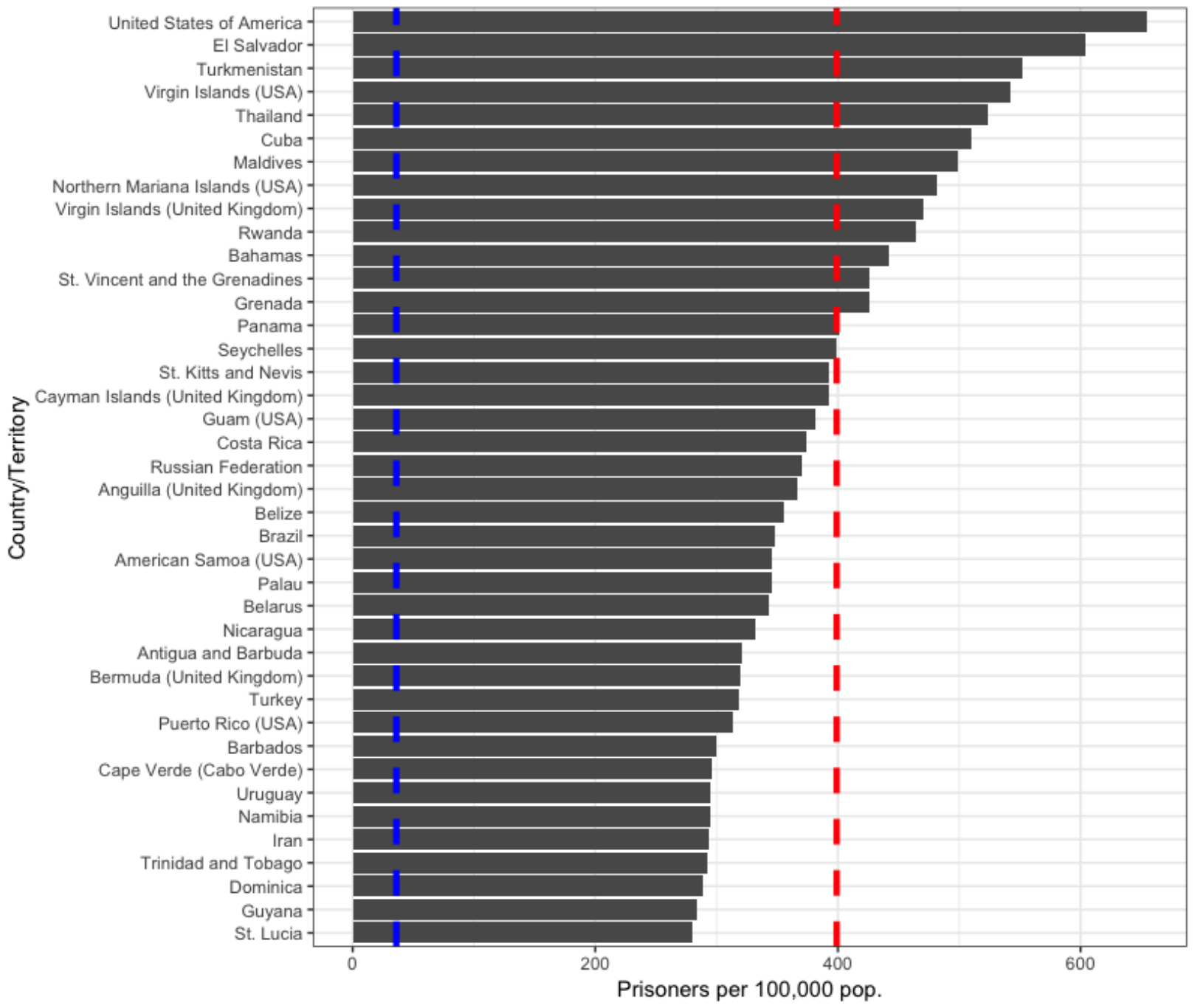

Figure 1: Top 40 countries/territories for incarceration rates, 2018 with Nigeria incarceration rates in red (year 1940) and blue (year 2018). Source: World Prison Brief 

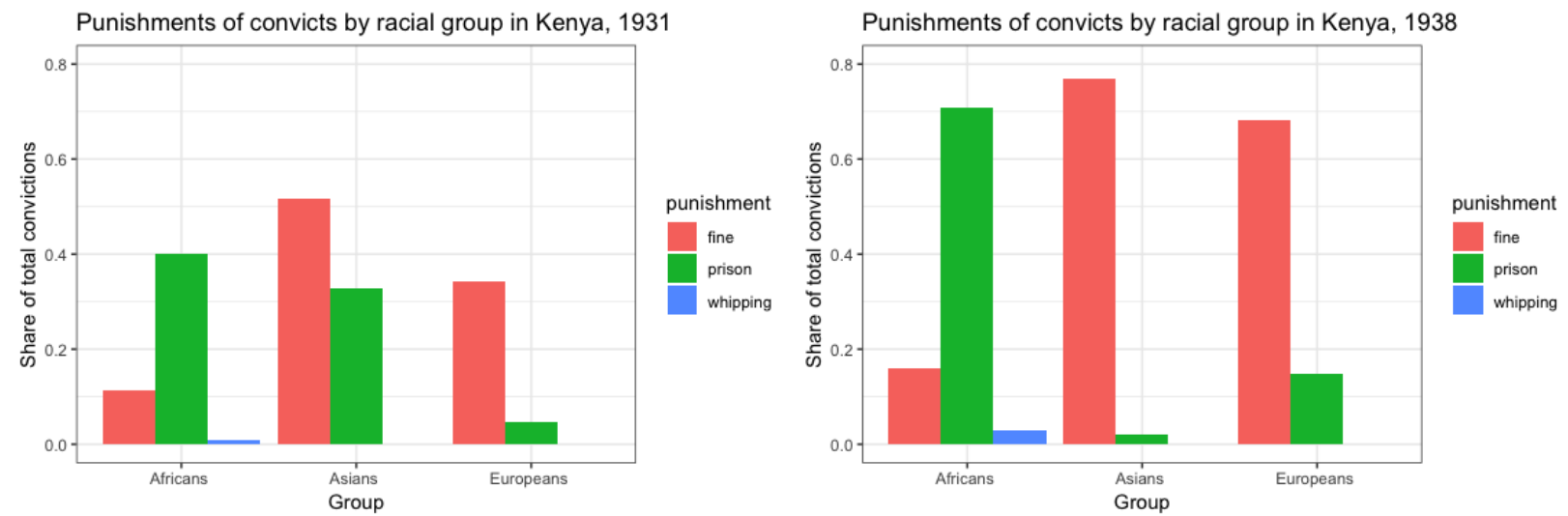

Figure 2: Punishment of convicts by race under Masters and Servants Ordinance in Kenya, 1931 and 1938. Source: Anderson (2000)

Share of total convictions by crime, $1920-1940$

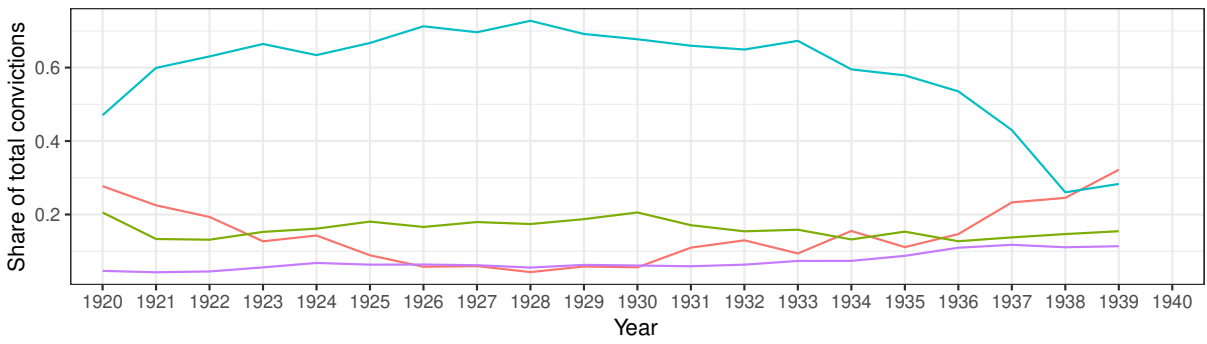

crime_convictions

— miscellaneous minor offences

— offences against property

— offences against revenue, road, social economy colony laws

— offences against the person

Share of total prison admissions by crime, 1977-1993

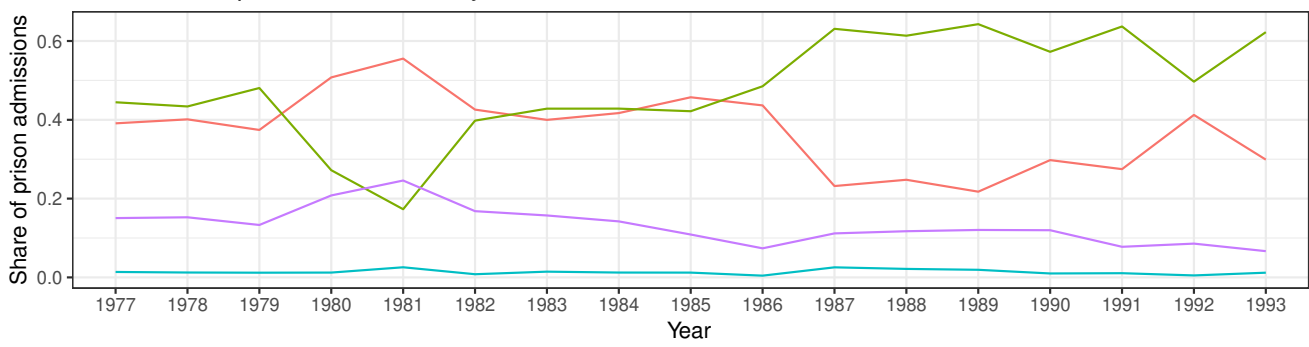

prison_admissions

- miscellaneous minor offences

- offences against property

— offences against revenue, social economy laws

— offences against the person

Figure 3: Share of total convictions in colonial courts and share of total prison admissions in postcolonial period by crime in Nigeria, 1920-1993. Source: see text 

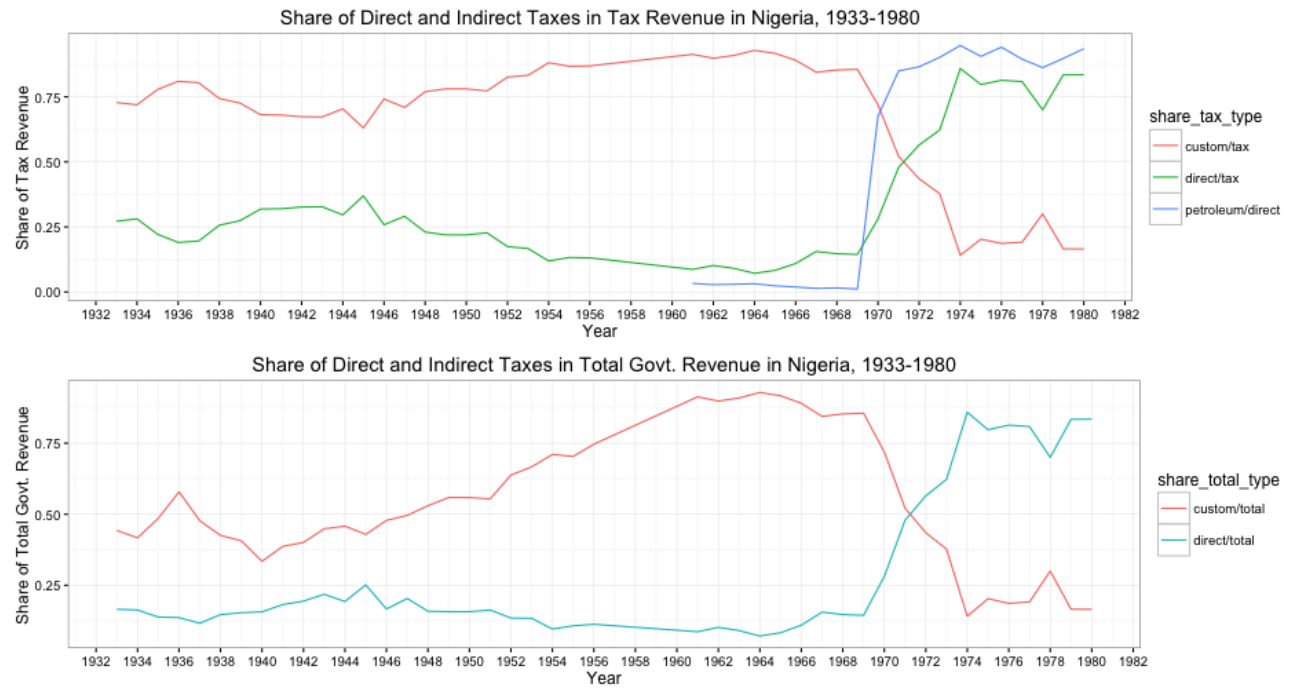

Figure 4: Composition of tax revenue in Nigeria, 1930-1980
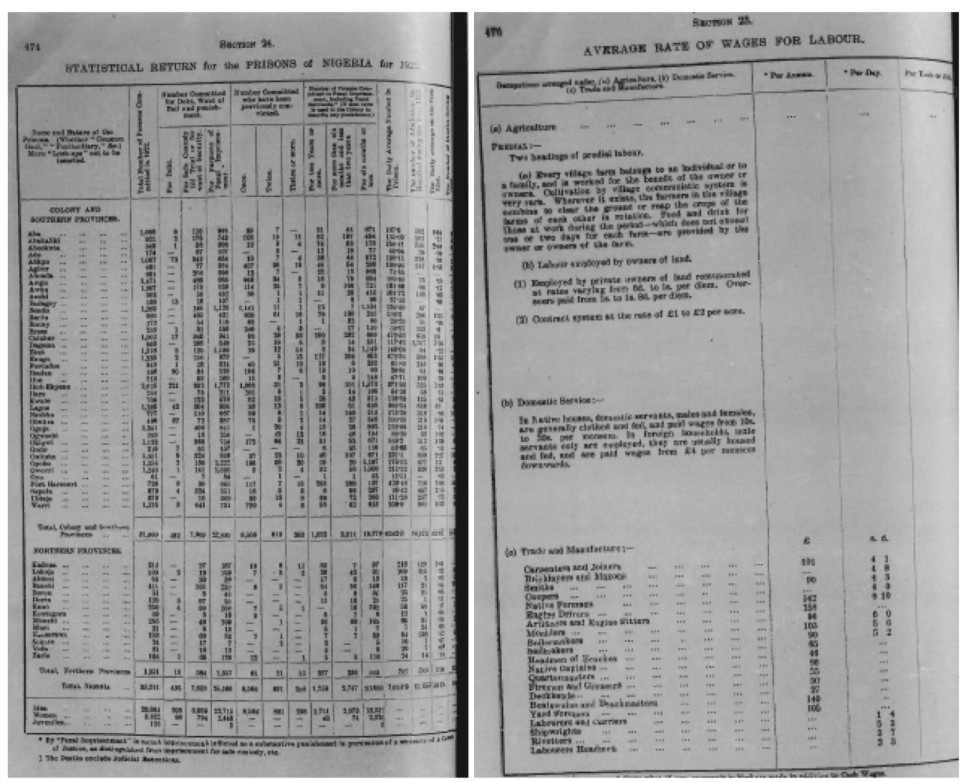

Figure 5: Example of archival data on prisons and wages from the British Blue Books (1922) 

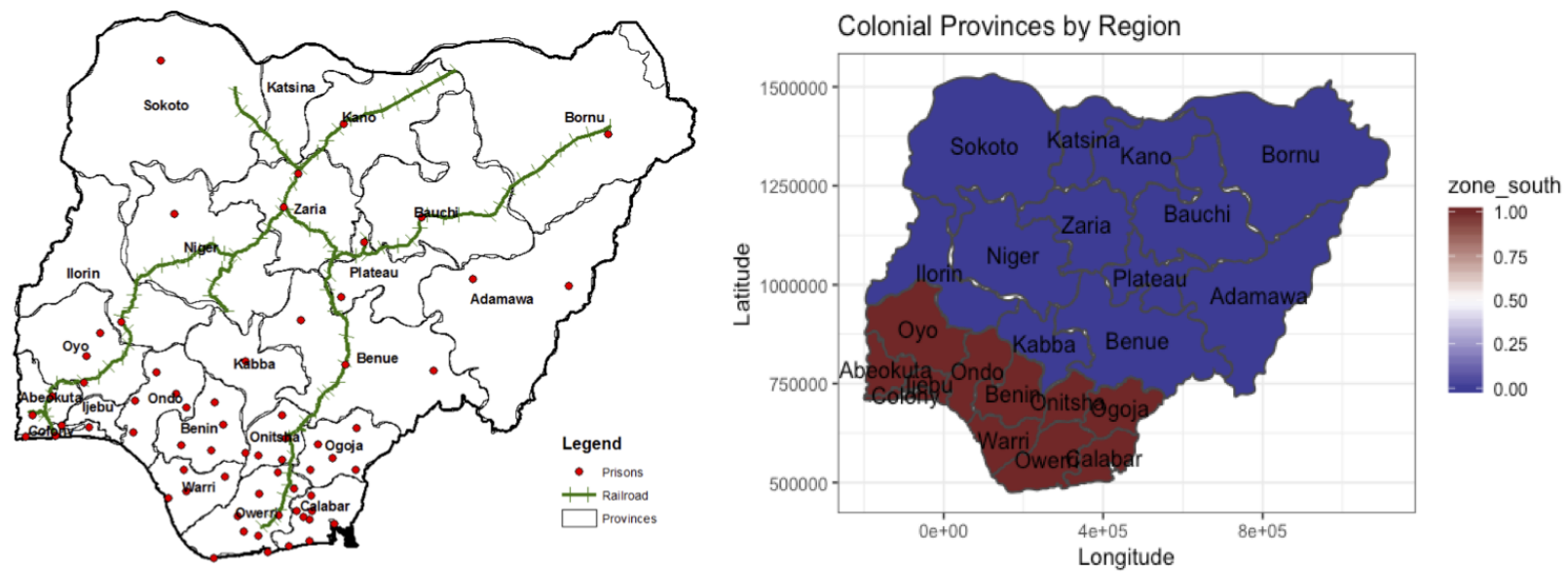

Figure 6: Nigeria provinces with colonial prison locations and railroad network shown (left) and regions (right)

(a) Annual average wage and prisoner costs, 1920-1959

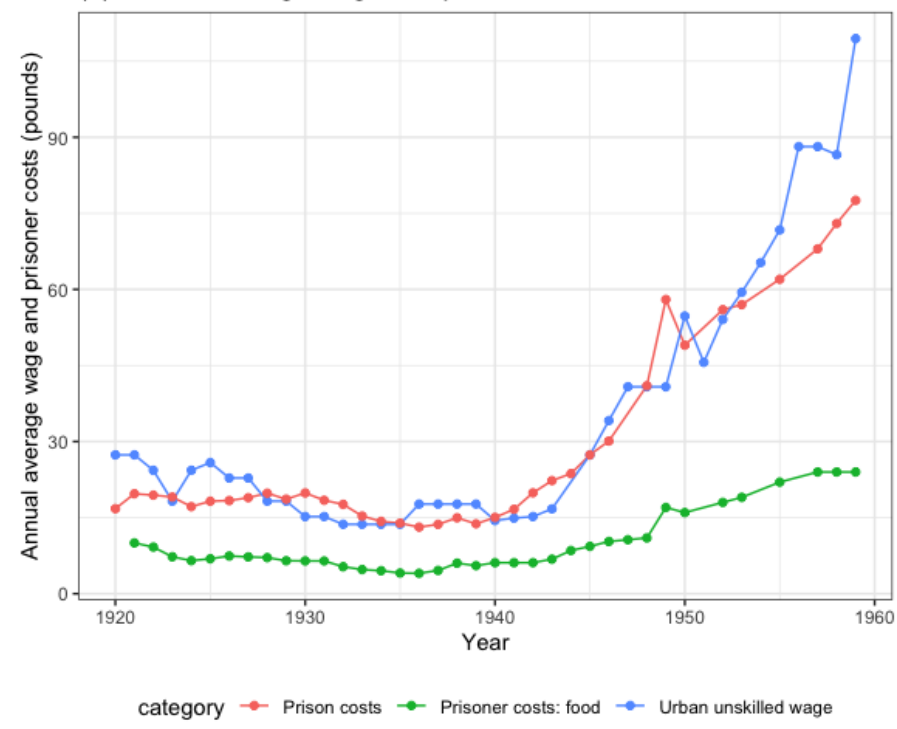

(b) Daily average number in prison

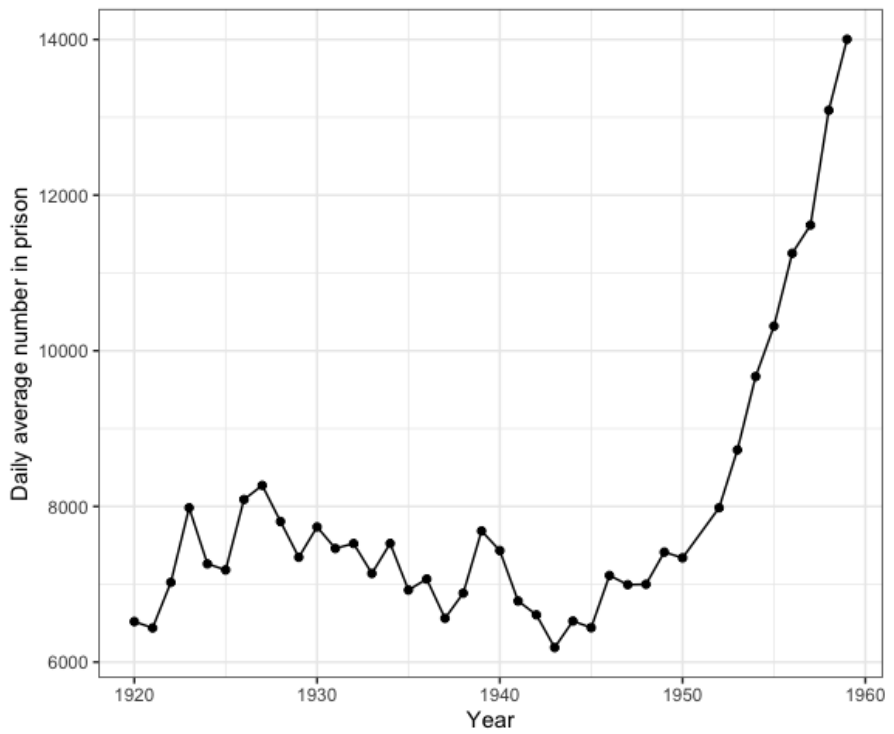

Figure 7: Wages, prisoner costs and daily average number in prisons in colonial Nigeria, 1920-1959 


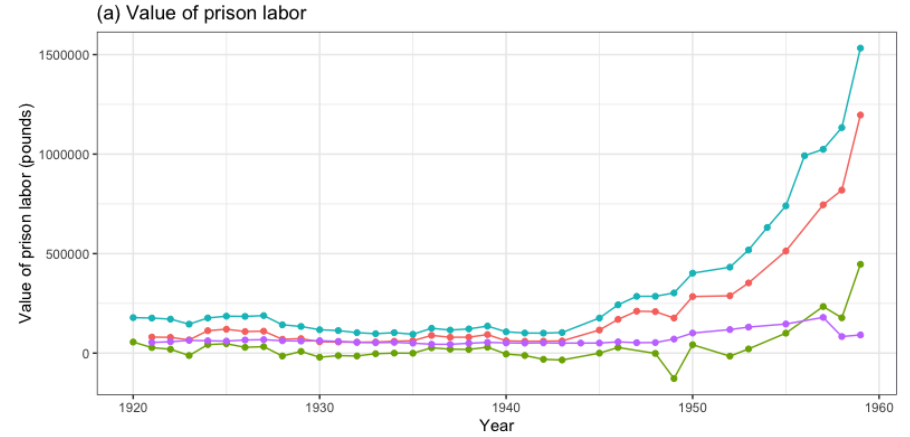

category $\rightarrow$ Net value less food costs $\rightarrow$ Net value less prison costs $\rightarrow$ Total value, estimate $\rightarrow$ Total value, reported

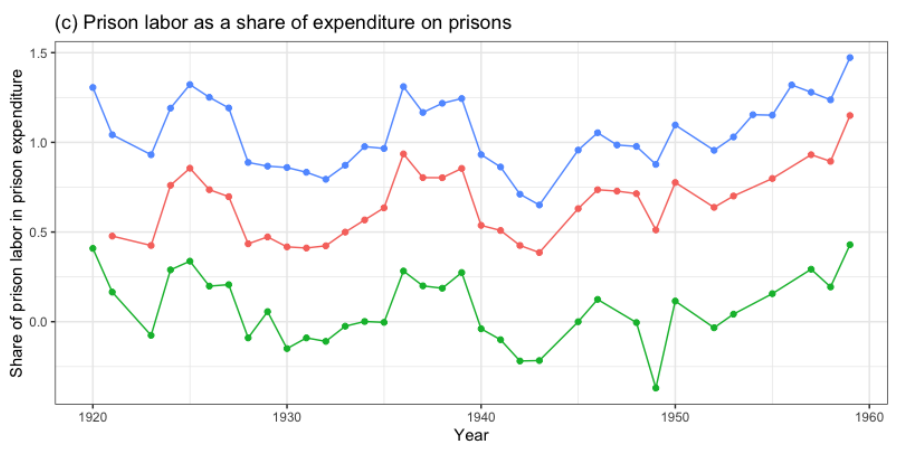

category $\rightarrow$ Net value less food costs/prison exp. $\rightarrow$ Net value less prison costs/prison exp. $\rightarrow$ Total value/prison exp. (b) Prison labor as a share of public works expenditure

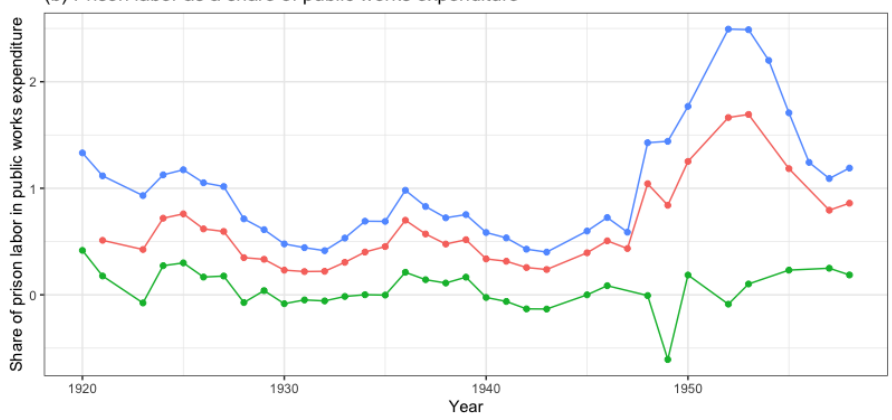

category $\rightarrow$ Net value less food costs/public works exp. $\rightarrow$ Net value less prison costs/public works exp. $\rightarrow$ Total value/public works exp

(d) Prison labor as a share of total expenditure

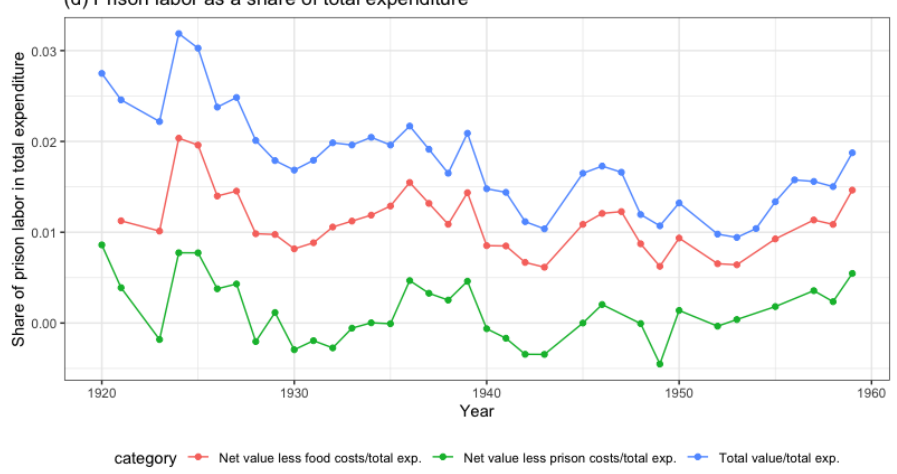

Figure 8: Relative value of prison labor, 1920-1959
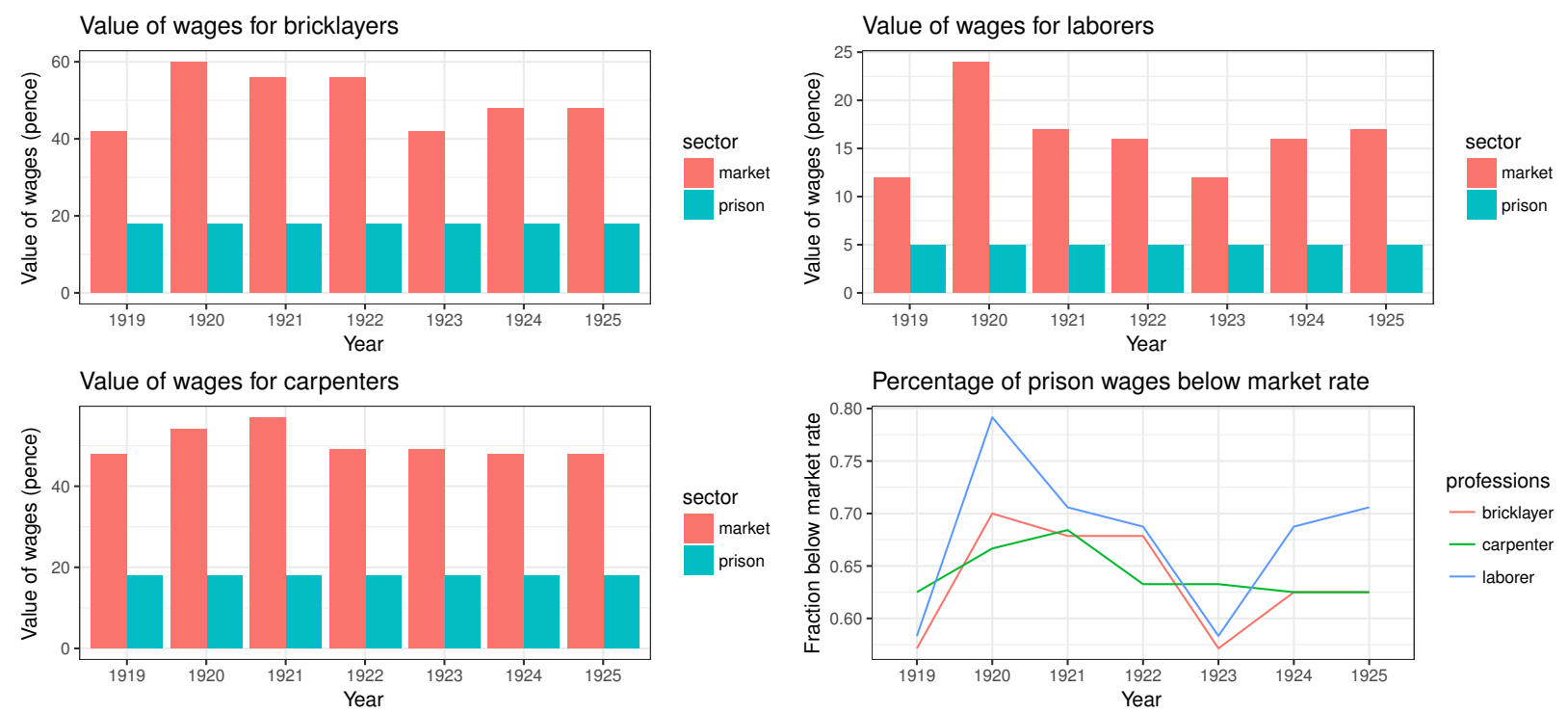

Figure 9: Value of wages for different skill categories in prison and market sectors, 1919-1925 


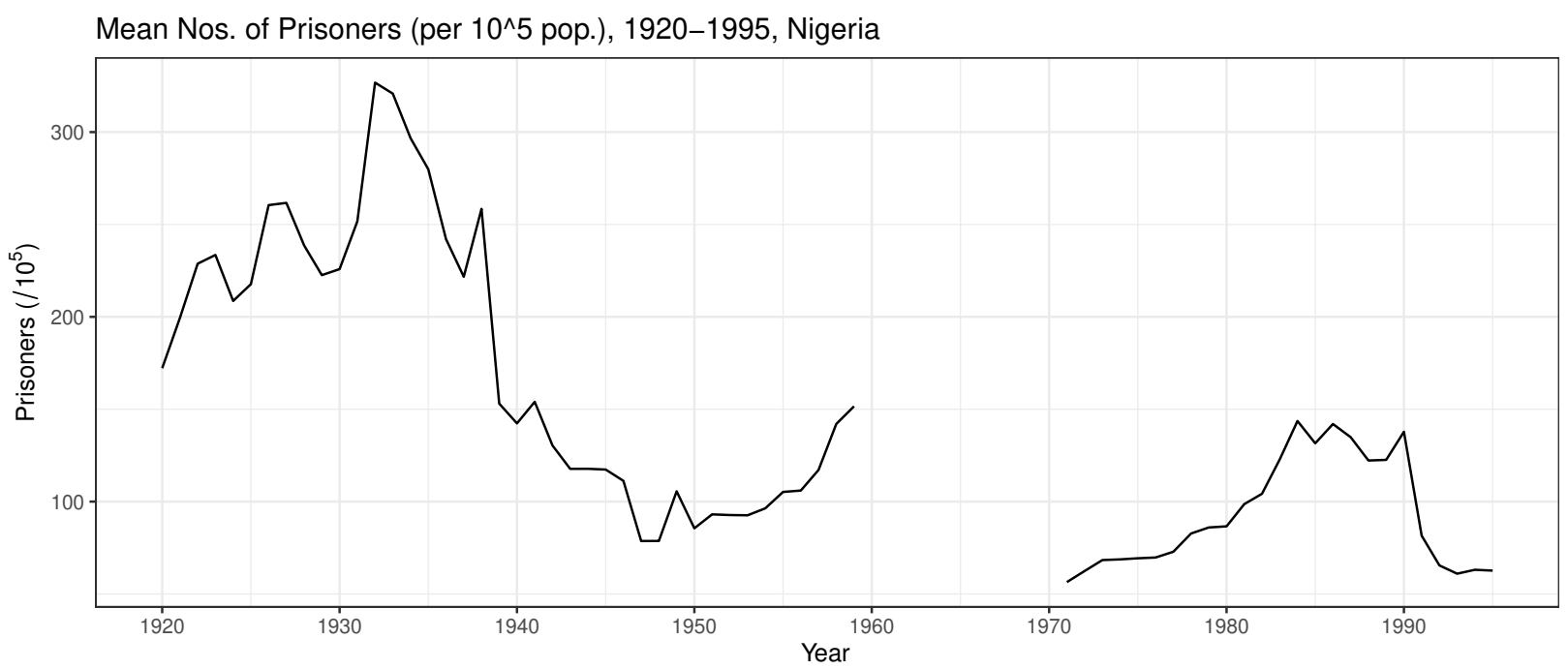

Figure 10: Mean number of prisoners per 100,000 population, 1920-1995
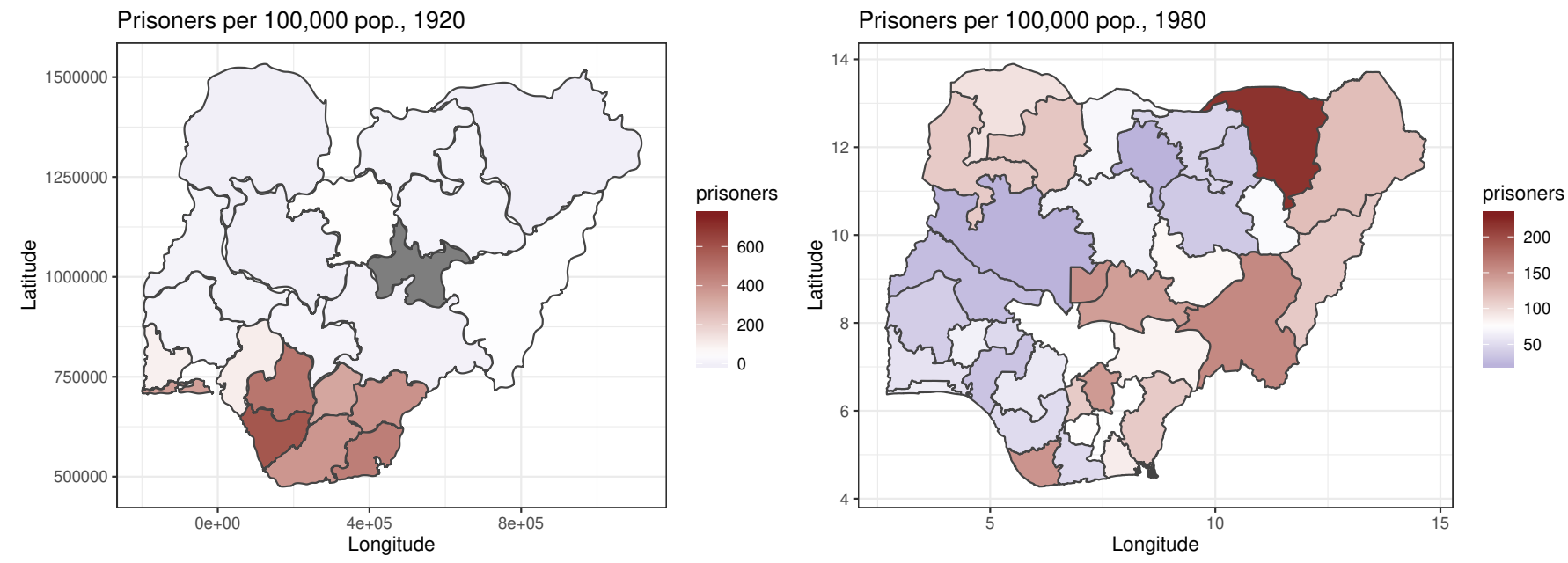

Figure 11: Prison populations in colonial (1920) and postcolonial (1980) Nigeria 
Table 1: Summary Statistics: Economic shocks and incarceration rates

\begin{tabular}{lrrrrr}
\hline \hline Statistic & N & Mean & St. Dev. & Min & Max \\
\hline & & & Prisoners, 1920-1938 & \\
& & & & & \\
& 324 & $1,811.76$ & $2,286.76$ & 3.00 & $10,231.00$ \\
All Prisoners Total & 324 & $1,251.83$ & $1,626.78$ & 2.00 & $7,010.00$ \\
Penal Imprisonment Total & 324 & 509.59 & 635.57 & 0.00 & $3,039.00$ \\
Custody Total & 324 & $1,051.05$ & $1,409.20$ & 2.00 & $6,377.00$ \\
Short-Term (<=6 Months) Total & 127.15 & 171.34 & 0.00 & 882.00 \\
Medium-Term (6Mo-2Y) Total & 324 & 68.93 & 84.10 & 0.00 & 417.00 \\
Long-Term (>=2yr) Total & 324 & 285.26 & 503.19 & 0.00 & $2,967.00$ \\
1 Previous Total & 324 & 49.51 & 73.51 & 0.00 & 503.00 \\
2 Previous Total & 324 & 31.80 & 48.07 & 0.00 & 321.00 \\
3 Previous Total & 324 & 240.73 & 254.56 & 0.26 & $1,123.30$ \\
All Prisoners /100,000 & 324 & 162.03 & 169.55 & 0.26 & 759.99 \\
Penal Imprisonment /100,000 & 324 & 71.73 & 83.47 & 0.00 & 333.66 \\
Custody /100,000 & 324 & 134.66 & 144.95 & 0.16 & 649.43 \\
Short-Term /100,000 & 324 & 16.56 & 18.26 & 0.00 & 80.45 \\
Medium-Term /100,000 & 324 & 10.18 & 12.88 & 0.00 & 83.45 \\
Long-Term /100,000 & 324 & 0.11 & 0.15 & 0.00 & 0.90 \\
Share w/ 1 Previous & 324 & 0.02 & 0.03 & 0.00 & 0.32 \\
Share w/ 2 Previous & 324 & 0.02 & 0.03 & 0.00 & 0.18 \\
Share w/ 3 Previous & 324 & & & &
\end{tabular}

Agricultural Commodities and Rainfall Deviation, 1920-1938

\begin{tabular}{llrrrr} 
Cocoa Producing & 393 & 0.15 & 0.35 & 0.00 & 1.00 \\
Groundnut Producing & 393 & 0.18 & 0.39 & 0.00 & 1.00 \\
Palm Oil Producing & 393 & 0.19 & 0.39 & 0.00 & 1.00 \\
Log Cocoa Price & 393 & 1.04 & 0.40 & 0.47 & 1.96 \\
Log Groundnut Price & 393 & 0.35 & 0.36 & -0.36 & 0.88 \\
Log Palm Oil Price & 393 & 0.72 & 0.53 & -0.22 & 1.69 \\
Rainfall Dev. & 393 & -0.00 & 0.97 & -2.21 & 4.08 \\
Rainfall Dev. Sq. & 393 & 0.95 & 1.83 & 0.00 & 16.67 \\
Positive Rainfall Shock (M) & 393 & 0.17 & 0.38 & 0.00 & 1.00 \\
Negative Rainfall Shock (E) & 393 & 0.30 & 0.46 & 0.00 & 1.00 \\
Positive Rainfall Shock (E) & 393 & 0.21 & 0.41 & 0.00 & 1.00 \\
\hline
\end{tabular}

Prisoners and Rainfall Deviation, 1971-1995

\begin{tabular}{lrrrrr} 
All Prisoners Total & 871 & $2,005.81$ & $1,210.56$ & 104.00 & $7,092.00$ \\
All Prisoners /100,000 & 871 & 92.48 & 60.43 & 9.91 & 361.99 \\
Share w/ 1 Previous* & 6 & 0.21 & 0.02 & 0.18 & 0.23 \\
Share w/ 2 Previous* & 6 & 0.12 & 0.02 & 0.10 & 0.16 \\
Share w/ 3 Previous* & 6 & 0.13 & 0.04 & 0.05 & 0.18 \\
Rainfall Dev. & 560 & 0.01 & 0.30 & -0.62 & 1.06 \\
Rainfall Dev. Sq. & 560 & 0.09 & 0.12 & 0.00 & 1.11 \\
Positive Rainfall Shock (M) & 560 & 0.49 & 0.50 & 0.00 & 1.00 \\
Negative Rainfall Shock (E) & 560 & 0.04 & 0.19 & 0.00 & 1.00 \\
Positive Rainfall Shock (E) & 560 & 0.01 & 0.11 & 0.00 & 1.00 \\
\hline
\end{tabular}

Notes: See text and online appendix for details. *denotes that data is based on available time series information from 1975-1980. 

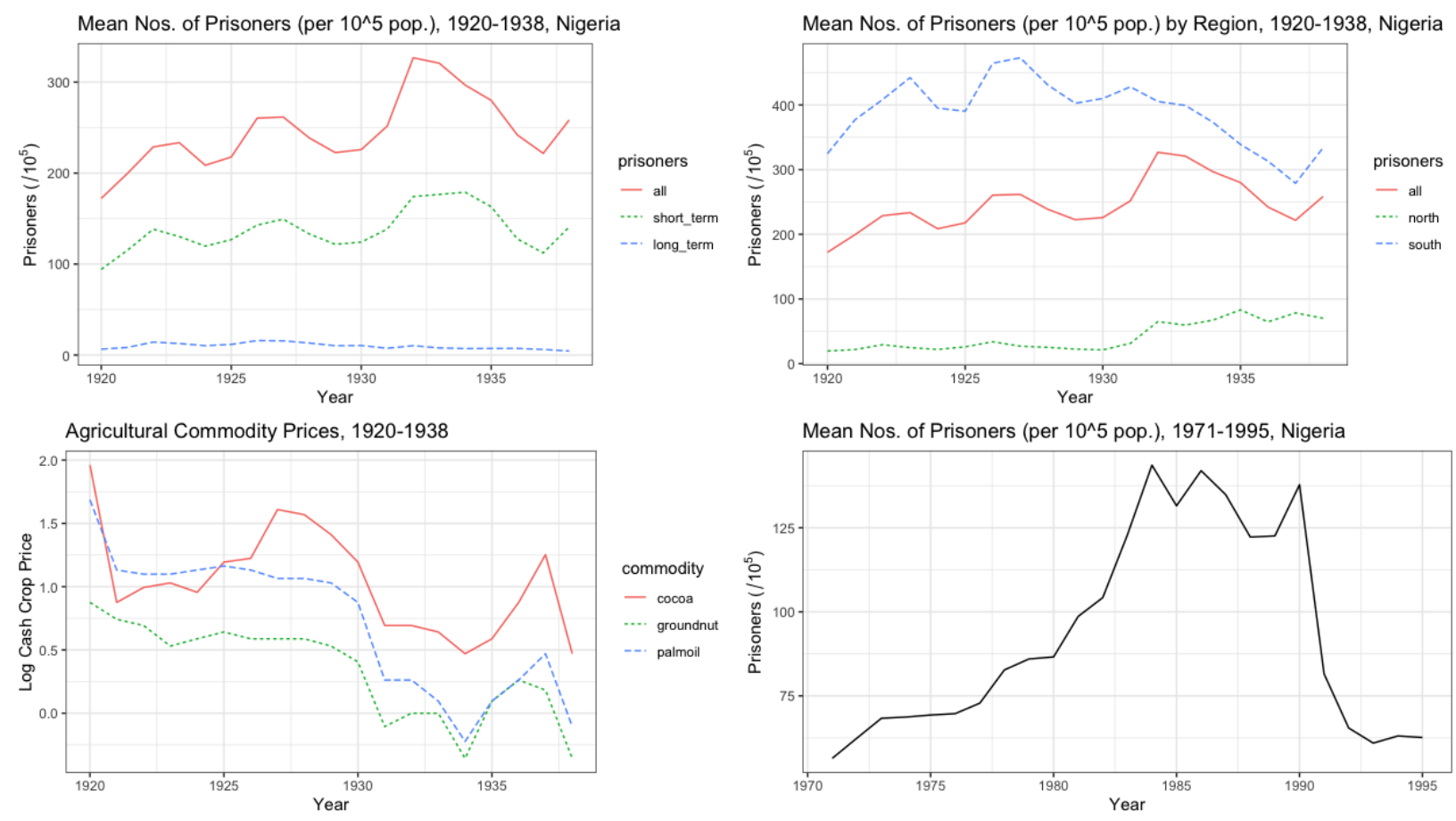

Figure 12: Prisoners and agricultural commodity prices, 1920-1995, Nigeria
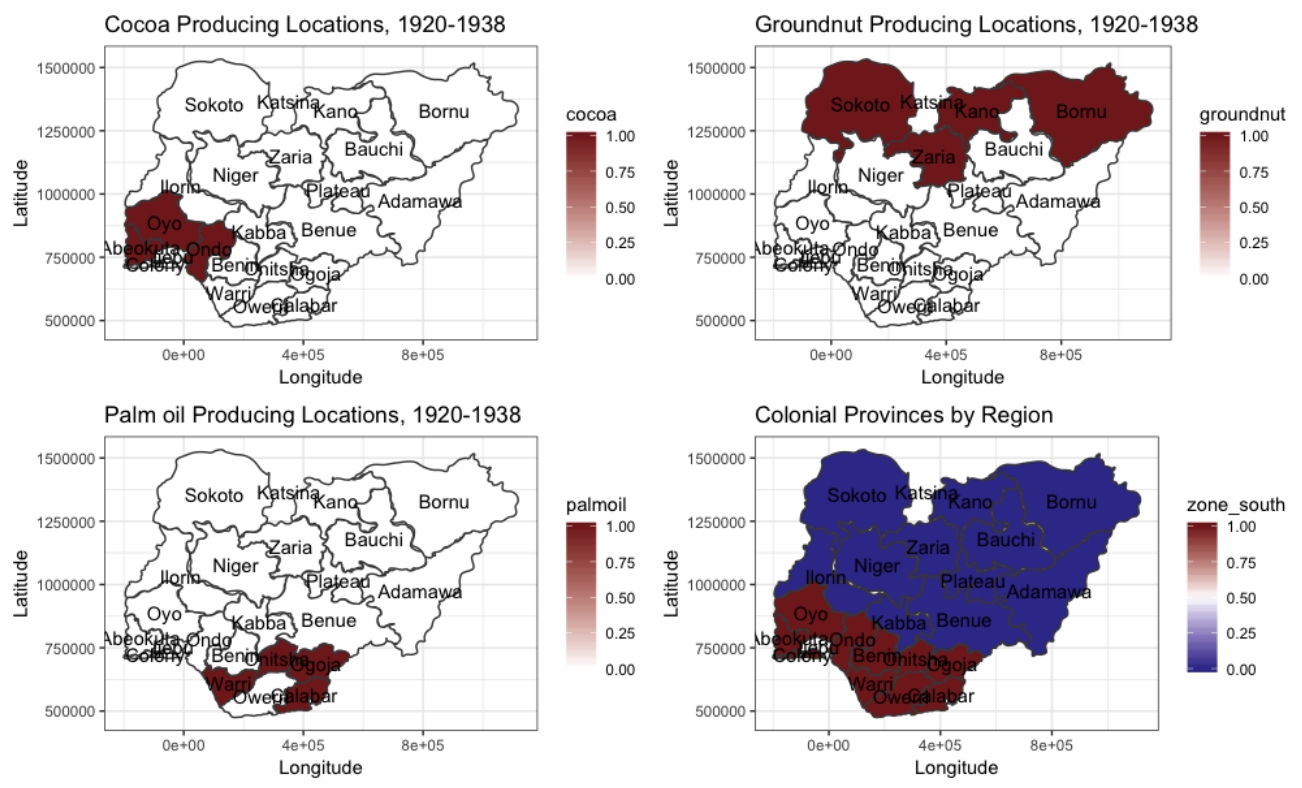

Figure 13: Agricultural commodity production in colonial Nigeria 
Table 2: Rainfall shocks and colonial (1920-1938) and postcolonial (1971-1995) incarceration rates

\begin{tabular}{lccccc}
\hline \hline & All Penal & Short-Term & Medium-Term & Long-Term & All 1971-95 \\
& $(1)$ & $(2)$ & $(3)$ & $(4)$ & $(5)$ \\
\hline Rainfall Dev & $14.147^{* *}$ & $11.995^{*}$ & 1.796 & 0.759 & -6.237 \\
& $(6.041)$ & $(6.433)$ & $(1.276)$ & $(1.227)$ & $(8.570)$ \\
& {$[0.038]$} & {$[0.065]$} & {$[0.212]$} & {$[0.655]$} & {$[0.454]$} \\
Rainfall Dev Sq & -3.569 & $-4.884^{*}$ & 0.205 & 0.752 & $34.275^{* * *}$ \\
& $(2.479)$ & $(2.816)$ & $(0.387)$ & $(0.739)$ & $(9.692)$ \\
& {$[0.246]$} & {$[0.068]$} & {$[0.629]$} & {$[0.494]$} & {$[<.001]$} \\
Mean of outcome & 162.032 & 134.659 & 16.556 & 10.175 & 104.802 \\
& & & & & \\
District FE & Yes & Yes & Yes & Yes & Yes \\
Year FE & Yes & Yes & Yes & Yes & Yes \\
Observations & 324 & 324 & 324 & 324 & 556 \\
Clusters & 21 & 21 & 21 & 21 & 36 \\
\hline \hline
\end{tabular}

Notes: Regressions estimated by OLS. Robust standard errors in parentheses clustered by district, where district is colonial province for colonial data, and postcolonial state for postcolonial data. Wild cluster bootstrap (by district) p-values are in brackets. Observations are provinces. Dependent variables in (1)-(5) are prisoners per 100,000 population (1939 pop.) by province in Nigeria broken down by all prisoners, penal imprisonment, custody/awaiting trial, short-term (less than 6 months) sentence and medium-term (between 6 months to 2 years) sentence and long-term (greater than 2 years) sentence over 1920-1938. Dependent variable in (6) is prisoners per 100,000 population (1990 pop.) by state in Nigeria. Results remain unchanged when we replace the denominator for the incarceration rates with the adult population of the province only. Rainfall deviation as defined in text. District FE are colonial province fixed effects in (1)-(5), and postcolonial state fixed effects in (6). ${ }^{* * *}$ Significant at the 1 percent level, ${ }^{* *}$ Significant at the 5 percent level, ${ }^{*}$ Significant at the 10 percent level based on clustered standard errors in parentheses. 
Table 3: Rainfall shocks and colonial (1920-1938) and postcolonial (1971-1995) incarceration rates by region

\begin{tabular}{|c|c|c|c|c|c|c|c|}
\hline & \multicolumn{3}{|c|}{ Short-Term } & \multicolumn{3}{|c|}{ Long-Term } & $\begin{array}{c}\text { All 1971-95 } \\
\text { All }\end{array}$ \\
\hline Rainfall Dev & $\begin{array}{c}11.995^{*} \\
(6.433) \\
{[0.065]}\end{array}$ & $\begin{array}{r}18.884^{*} \\
(11.046) \\
{[0.142]}\end{array}$ & $\begin{array}{c}1.978 \\
(1.234) \\
{[0.205]}\end{array}$ & $\begin{array}{c}0.759 \\
(1.227) \\
{[0.655]}\end{array}$ & $\begin{array}{r}-0.071 \\
(2.201) \\
{[0.989]}\end{array}$ & $\begin{array}{c}0.236 \\
(0.338) \\
{[0.544]}\end{array}$ & $\begin{array}{r}-6.237 \\
(8.570) \\
{[0.454]}\end{array}$ \\
\hline Rainfall Dev Sq & $\begin{array}{r}-4.884^{*} \\
(2.816) \\
{[0.068]}\end{array}$ & $\begin{array}{c}-8.686^{* *} \\
(4.235) \\
{[0.046]}\end{array}$ & $\begin{array}{l}0.860^{* * *} \\
(0.309) \\
{[<.001]}\end{array}$ & $\begin{array}{c}0.752 \\
(0.739) \\
{[0.494]}\end{array}$ & $\begin{array}{c}1.381 \\
(1.346) \\
{[0.541]}\end{array}$ & $\begin{array}{c}0.062 \\
(0.098) \\
{[0.675]}\end{array}$ & $\begin{array}{l}34.275^{\text {*** }} \\
(9.692) \\
{[<.001]}\end{array}$ \\
\hline Mean of outcome & 134.659 & 217.517 & 18.657 & 10.175 & 14.743 & 3.781 & 104.802 \\
\hline District FE & Yes & Yes & Yes & Yes & Yes & Yes & Yes \\
\hline Year FE & Yes & Yes & Yes & Yes & Yes & Yes & Yes \\
\hline Observations & 324 & 189 & 135 & 324 & 189 & 135 & 556 \\
\hline Clusters & 21 & 10 & 11 & 21 & 10 & 11 & 36 \\
\hline
\end{tabular}

Notes: Regressions estimated by OLS. Robust standard errors in parentheses clustered by district, where district is colonial province for colonial data, and postcolonial state for postcolonial data. Wild cluster bootstrap (by district) p-values are in brackets. Dependent variables are prisoners per 100,000 population (1939 pop.) by province in Nigeria broken down by short-term (less than 6 months) sentence and long-term (greater than 2 years) sentence over 1920-1938, for all provinces and Southern and Northern Provinces separately; and prisoners per 100,000 population (1990 pop.) in the postcolonial era from 1971-1995 by state in Nigeria in the last column. District $\mathrm{FE}$ are colonial province fixed effects for colonial data, and and postcolonial state fixed effects for postcolonial data. ${ }^{* * *}$ Significant at the 1 percent level, ${ }^{* *}$ Significant at the 5 percent level, *Significant at the 10 percent level based on clustered standard errors in parentheses. 
Table 4: Rainfall shocks (by type) and colonial (1920-1938) and postcolonial (1971-1995) incarceration rates breakdown

\begin{tabular}{|c|c|c|c|c|c|c|c|c|c|}
\hline & \multicolumn{3}{|c|}{ Short-Term } & \multicolumn{3}{|c|}{ Long-Term } & \multicolumn{3}{|c|}{ All 1971-95 } \\
\hline & $(1)$ & $(2)$ & $(3)$ & $(4)$ & $(5)$ & $(6)$ & $(7)$ & $(8)$ & $(9)$ \\
\hline Positive rainfall shock (M) & $\begin{array}{l}16.727^{* * *} \\
(5.456) \\
{[0.016]}\end{array}$ & & $\begin{array}{c}12.142^{*} \\
(6.964) \\
{[0.093]}\end{array}$ & $\begin{array}{c}-1.638 \\
(1.319) \\
{[0.336]}\end{array}$ & & $\begin{array}{c}-0.695 \\
(1.437) \\
{[0.683]}\end{array}$ & $\begin{array}{r}-4.387 \\
(4.132) \\
{[0.320]}\end{array}$ & & $\begin{array}{c}-2.320 \\
(4.564) \\
{[0.620]}\end{array}$ \\
\hline Negative rainfall shock (E) & & $\begin{array}{c}-20.290^{* *} \\
(9.484) \\
{[0.057]}\end{array}$ & $\begin{array}{r}-17.225^{*} \\
(10.259) \\
{[0.139]}\end{array}$ & & $\begin{array}{c}-1.060 \\
(2.894) \\
{[0.762]}\end{array}$ & $\begin{array}{c}-0.429 \\
(3.530) \\
{[0.886]}\end{array}$ & & $\begin{array}{c}22.722^{\text {*** }} \\
(7.814) \\
{[0.016]}\end{array}$ & $\begin{array}{l}22.545^{* * *} \\
(7.807) \\
{[0.012]}\end{array}$ \\
\hline Positive rainfall shock (E) & & & $\begin{array}{r}-0.404 \\
(13.973) \\
{[0.977]}\end{array}$ & & & $\begin{array}{c}3.358 \\
(2.654) \\
{[0.293]}\end{array}$ & & & $\begin{array}{c}20.423^{* *} \\
(8.268) \\
{[0.046]}\end{array}$ \\
\hline Mean of outcome & 134.659 & 134.659 & 134.659 & 10.175 & 10.175 & 10.175 & 104.802 & 104.802 & 104.802 \\
\hline District FE & Yes & Yes & Yes & Yes & Yes & Yes & Yes & Yes & Yes \\
\hline Year FE & Yes & Yes & Yes & Yes & Yes & Yes & Yes & Yes & Yes \\
\hline Observations & 324 & 324 & 324 & 324 & 324 & 324 & 556 & 556 & 556 \\
\hline Clusters & 21 & 21 & 21 & 21 & 21 & 21 & 36 & 36 & 36 \\
\hline
\end{tabular}

Notes: Regressions estimated by OLS. Robust standard errors in parentheses clustered by district, where district is colonial province for colonial data, and postcolonial state for postcolonial data. Wild cluster bootstrap (by district) p-values are in brackets. Observations are districts. Dependent variables in (1)-(6) are prisoners per 100,000 population (1939 pop.) by province in Nigeria broken down by short-term (less than 6 months) sentence( (1)-(3)) and long-term (greater than 2 years) sentence((4)-(6)) over 1920-1938. Dependent variable in (7)-(9) is prisoners per 100,000 population (1990 pop.) by state in Nigeria. Positive rainfall shock (M) where (M) is moderate, and (E) is extreme as defined in text. District FE are colonial province fixed effects in (1)-(6), and postcolonial state fixed effects in (7)-(9). ${ }^{* * *}$ Significant at the 1 percent level, ${ }^{* *}$ Significant at the 5 percent level, ${ }^{*}$ Significant at the 10 percent level based on clustered standard errors in parentheses. 
Table 5: Rainfall shocks and colonial (1920-1938) and postcolonial (1971-1995) incarceration rates by region

\begin{tabular}{|c|c|c|c|c|c|c|c|}
\hline & \multicolumn{3}{|c|}{ Short-Term } & \multicolumn{3}{|c|}{ Long-Term } & \multirow{2}{*}{$\begin{array}{c}\text { All 1971-95 } \\
\text { All }\end{array}$} \\
\hline & All & South & North & All & South & North & \\
\hline Positive rainfall shock (M) & $\begin{array}{l}16.727^{\text {*** }} \\
(5.456) \\
{[0.016]}\end{array}$ & $\begin{array}{l}24.826^{* * *} \\
(7.795) \\
{[0.009]}\end{array}$ & $\begin{array}{c}0.392 \\
(1.086) \\
{[0.729]}\end{array}$ & $\begin{array}{r}-1.638 \\
(1.319) \\
{[0.336]}\end{array}$ & $\begin{array}{c}-2.609 \\
(2.127) \\
{[0.408]}\end{array}$ & $\begin{array}{r}-0.573 \\
(0.446) \\
{[0.174]}\end{array}$ & $\begin{array}{r}-4.387 \\
(4.132) \\
{[0.320]}\end{array}$ \\
\hline Mean of outcome & 134.659 & 217.517 & 18.657 & 10.175 & 14.743 & 3.781 & 104.802 \\
\hline District FE & Yes & Yes & Yes & Yes & Yes & Yes & Yes \\
\hline Year FE & Yes & Yes & Yes & Yes & Yes & Yes & Yes \\
\hline Observations & 324 & 189 & 135 & 324 & 189 & 135 & 556 \\
\hline Clusters & 21 & 21 & 21 & 21 & 21 & 21 & 36 \\
\hline
\end{tabular}

Notes: Regressions estimated by OLS. Robust standard errors in parentheses clustered by district, where district is colonial province for colonial data, and postcolonial state for postcolonial data. Wild cluster bootstrap (by district) p-values are in brackets. Observations are provinces. Dependent variables in (1)-(6) are prisoners per 100,000 population (1939 pop.) by province in Nigeria broken down by short-term (less than 6 months) sentence( (1)-(3))and long-term (greater than 2 years) sentence((4)-(6)) over 1920-1938. Dependent variable in (7) is prisoners per 100,000 population (1990 pop.) by state in Nigeria. Positive rainfall shock (M) where (M) is moderate as defined in text. District FE are colonial province fixed effects in (1)-(6), and postcolonial state fixed effects in (7). ${ }^{* * *}$ Significant at the 1 percent level, ${ }^{* *}$ Significant at the 5 percent level, ${ }^{*}$ Significant at the 10 percent level based on clustered standard errors in parentheses. 
Table 6: Rainfall shocks (by type) and colonial (1920-1938) incarceration rates by custody/awaiting trial category

\begin{tabular}{|c|c|c|c|c|c|c|}
\hline & \multicolumn{2}{|c|}{ Custody } & \multicolumn{2}{|c|}{ Short-Term } & \multicolumn{2}{|c|}{ Custody - Short-Term } \\
\hline & (1) & $(2)$ & (3) & $(4)$ & $(5)$ & (6) \\
\hline Positive rainfall shock (M) & $\begin{array}{c}5.623^{* *} \\
(2.201) \\
{[0.014]}\end{array}$ & $\begin{array}{c}1.774 \\
(2.795) \\
{[0.558]}\end{array}$ & $\begin{array}{l}16.727^{* * *} \\
(5.456) \\
{[0.016]}\end{array}$ & $\begin{array}{c}12.142^{*} \\
(6.964) \\
{[0.093]}\end{array}$ & $\begin{array}{c}-11.104^{* *} \\
(4.554) \\
{[0.040]}\end{array}$ & $\begin{array}{r}-10.368 \\
(6.475) \\
{[0.154]}\end{array}$ \\
\hline Negative rainfall shock (E) & & $\begin{array}{r}-6.703 \\
(6.396) \\
{[0.371]}\end{array}$ & & $\begin{array}{r}-17.225^{*} \\
(10.259) \\
{[0.139]}\end{array}$ & & $\begin{array}{c}10.523 \\
(8.004) \\
{[0.241]}\end{array}$ \\
\hline Positive rainfall shock (E) & & $\begin{array}{r}-6.734^{*} \\
(4.044) \\
{[0.093]}\end{array}$ & & $\begin{array}{r}-0.404 \\
(13.973) \\
{[0.977]}\end{array}$ & & $\begin{array}{r}-6.331 \\
(13.161) \\
{[0.615]}\end{array}$ \\
\hline Mean of outcome & 71.727 & 71.727 & 134.659 & 134.659 & -62.932 & -62.932 \\
\hline District FE & Yes & Yes & Yes & Yes & Yes & Yes \\
\hline Year FE & Yes & Yes & Yes & Yes & Yes & Yes \\
\hline Observations & 324 & 324 & 324 & 324 & 324 & 324 \\
\hline Clusters & 21 & 21 & 21 & 21 & 21 & 21 \\
\hline
\end{tabular}

Notes: Regressions estimated by OLS. Robust standard errors in parentheses clustered by district, where district is colonial province for colonial data, and postcolonial state for postcolonial data. Wild cluster bootstrap (by district) p-values are in brackets. Observations are provinces. Dependent variables in (1)-(2) and (3)-(4) are prisoners awaiting custody or trial per 100,000 population (1939 pop.) and short-term prisoners with less than 6 months sentences respectively. Outcome in (5)-(6) is the difference between the custody/awaiting trial incarceration rate and the short-term, less than 6 months sentence incarceration rate. Positive rainfall shock $(\mathrm{M})$ where $(\mathrm{M})$ is moderate, and (E) is extreme as defined in text. District FE are colonial province fixed effects in (1)-(6). ${ }^{* * *}$ Significant at the 1 percent level, ${ }^{* *}$ Significant at the 5 percent level, ${ }^{*}$ Significant at the 10 percent level based on clustered standard errors in parentheses. 
Table 7: Agricultural commodity prices and colonial incarceration rates

\begin{tabular}{|c|c|c|c|c|c|c|c|c|}
\hline & \multicolumn{4}{|c|}{ Short-Term } & \multicolumn{4}{|c|}{ Long-Term } \\
\hline & $(1)$ & $(2)$ & $(3)$ & $(4)$ & $(5)$ & $(6)$ & $(7)$ & $(8)$ \\
\hline \multirow[t]{3}{*}{ Palm Oil } & $213.481^{* * *}$ & $193.727^{* * *}$ & & & $12.583^{* * *}$ & $6.707^{* *}$ & & \\
\hline & $(19.240)$ & $(18.204)$ & & & $(2.468)$ & $(2.444)$ & & \\
\hline & {$[0.016]$} & {$[0.012]$} & & & $[0.052])$ & {$[0.083]$} & & \\
\hline \multirow[t]{3}{*}{ Palm Oil Price } & 76.228 & -14.926 & & & 2.874 & 2.562 & & \\
\hline & $(45.982)$ & $(10.848)$ & & & $(5.314)$ & $(1.753)$ & & \\
\hline & {$[0.112]$} & {$[0.167]$} & & & {$[0.554]$} & {$[0.1271]$} & & \\
\hline \multirow[t]{3}{*}{ Palm Oil x Palm Oil Price } & $72.530^{* *}$ & $68.649^{* *}$ & & & 1.588 & 4.151 & & \\
\hline & $(29.037)$ & $(25.441)$ & & & $(4.355)$ & $(3.416)$ & & \\
\hline & {$[0.065]$} & {$[0.049]$} & & & {$[0.724]$} & {$[0.271]$} & & \\
\hline \multirow[t]{3}{*}{ Cocoa } & -8.002 & & $-38.358^{*}$ & & $11.415^{* * *}$ & & 0.347 & \\
\hline & $(19.462)$ & & $(18.619)$ & & $(3.973)$ & & $(2.822)$ & \\
\hline & {$[0.718]$} & & {$[0.190]$} & & {$[0.061]$} & & {$[0.929]$} & \\
\hline \multirow[t]{3}{*}{ Cocoa Price } & $-103.894^{*}$ & & 3.114 & & -2.300 & & $5.608^{* * *}$ & \\
\hline & $(51.324)$ & & $(11.865)$ & & $(5.266)$ & & $(1.839)$ & \\
\hline & {$[0.055]$} & & {$[0.781]$} & & {$[0.664]$} & & {$[0.010]$} & \\
\hline \multirow[t]{3}{*}{ Cocoa x Cocoa Price } & 29.450 & & 4.146 & & -7.111 & & $-6.535^{* *}$ & \\
\hline & $(21.660)$ & & $(17.959)$ & & $(4.520)$ & & $(2.722)$ & \\
\hline & {$[0.219]$} & & {$[0.824]$} & & {$[0.166]$} & & {$[0.086]$} & \\
\hline \multirow[t]{3}{*}{ Groundnut } & $60.686^{* * *}$ & & & $50.839^{* * *}$ & $13.839^{* * *}$ & & & $9.547^{* * *}$ \\
\hline & $(6.220)$ & & & $(9.245)$ & $(1.127)$ & & & $(1.198)$ \\
\hline & {$[0.233]$} & & & {$[0.238]$} & {$[0.146]$} & & & {$[0.098]$} \\
\hline \multirow[t]{3}{*}{ Groundnut Price } & -13.026 & & & 12.731 & 6.516 & & & $6.816^{* * *}$ \\
\hline & $(12.409)$ & & & $(14.857)$ & $(4.263)$ & & & $(2.204)$ \\
\hline & {$[0.269]$} & & & {$[0.407]$} & {$[0.075]$} & & & {$[<.001]$} \\
\hline \multirow[t]{3}{*}{ Groundnut x Groundnut Price } & -11.989 & & & $-49.111^{*}$ & $-9.858^{*}$ & & & $-9.130^{* *}$ \\
\hline & $(27.752)$ & & & $(27.060)$ & $(5.419)$ & & & $(3.505)$ \\
\hline & {$[0.694]$} & & & {$[0.245]$} & {$[0.145]$} & & & {$[0.119]$} \\
\hline Mean of outcome & 134.659 & 134.659 & 134.659 & 134.659 & 10.175 & 10.175 & 10.175 & 10.175 \\
\hline District FE & Yes & Yes & Yes & Yes & Yes & Yes & Yes & Yes \\
\hline Year FE & Yes & Yes & Yes & Yes & Yes & Yes & Yes & Yes \\
\hline Observations & 324 & 324 & 324 & 324 & 324 & 324 & 324 & 324 \\
\hline Clusters & 21 & 21 & 21 & 21 & 21 & 21 & 21 & 21 \\
\hline
\end{tabular}

Notes: Regressions estimated by OLS. Robust standard errors in parentheses clustered by district, where district is colonial province for colonial data. Wild cluster bootstrap (by district) p-values are in brackets. Observations are provinces. Dependent variables are prisoners per 100,000 population (1939 pop.) by province in Nigeria broken down by short-term (less than 6 months) sentence and long-term (greater than 2 years) sentence over 1920-1938. Prices are in logs. District FE are colonial province fixed effects. ${ }^{* * *}$ Significant at the 1 percent level, ${ }^{* *}$ Significant at the 5 percent level, *Significant at the 10 percent level. 
Table 8: Effect of wages and distance to railroad on colonial incarceration rates

\begin{tabular}{lcccc}
\hline \hline & \multicolumn{2}{c}{ Short-Term } & \multicolumn{2}{c}{ Long-Term } \\
& $(1)$ & $(2)$ & $(3)$ & $(4)$ \\
\hline Distance to railroad & $-0.301^{*}$ & $-1.479^{*}$ & -0.018 & -0.029 \\
& $(0.165)$ & $(0.713)$ & $(0.023)$ & $(0.104)$ \\
& {$[0.005]$} & {$[0.010]$} & {$[0.440]$} & {$[0.807]$} \\
Log wages & & -4.390 & & 3.254 \\
& $(10.376)$ & & $(2.744)$ \\
Distance x Log wages & & {$[0.655]$} & & $0.215]$ \\
& & $0.401^{*}$ & & 0.004 \\
& & $(0.200)$ & & $0.035)$ \\
Mean of outcome & & {$[0.038]$} & & $3.927]$ \\
& 46.198 & 46.198 & 3.990 & \\
District FE & & & & Yes \\
Year FE & Yes & Yes & Yes & Yes \\
Observations & Yes & Yes & Yes & 21 \\
Clusters & 938 & 938 & 822 & 21 \\
\hline \hline
\end{tabular}

Notes: Regressions estimated by OLS. Robust standard errors in parentheses clustered by district, where district is colonial province for colonial data. Wild cluster bootstrap (by district) p-values are in brackets. Observations are individual prisons. Dependent variables in (1)-(4) are prisoners in each prison per 100,000 population of the province broken down by short-term (less than 6 months) sentence and long-term (greater than 2 years) sentence over 1920-1938. Covariates are distance to railroad in $\mathrm{km}$ and log urban unskilled wages. District FE are colonial province fixed effects in (1)-(4). ${ }^{* * *}$ Significant at the 1 percent level, ${ }^{* *}$ Significant at the 5 percent level, ${ }^{*}$ Significant at the 10 percent level based on clustered standard errors in parentheses. 
Table 9: OLS Estimates: Relationship between colonial imprisonment and present-day trust in historical legal Institutions versus interpersonal trust

\begin{tabular}{|c|c|c|c|c|c|c|}
\hline & \multicolumn{3}{|c|}{ Trust in Historical Legal Institutions } & \multicolumn{3}{|c|}{ Interpersonal Trust } \\
\hline & $\begin{array}{c}\text { Police } \\
(1) \\
\end{array}$ & $\begin{array}{c}\text { Courts } \\
(2) \\
\end{array}$ & $\begin{array}{l}\text { Tax } \\
(3)\end{array}$ & $\begin{array}{c}\text { Neighbors } \\
(4)\end{array}$ & $\begin{array}{c}\text { Relatives } \\
(5)\end{array}$ & $\begin{array}{c}\text { Local Gov } \\
(6)\end{array}$ \\
\hline Prisoners per 100,000 pop. & $\begin{array}{c}-0.013^{* * *} \\
(0.004) \\
{[0.003]}\end{array}$ & $\begin{array}{r}-0.007^{*} \\
(0.004) \\
{[0.080]}\end{array}$ & $\begin{array}{c}-0.015^{* * *} \\
(0.005) \\
{[0.063]}\end{array}$ & $\begin{array}{r}-0.010 \\
(0.011) \\
{[0.442]}\end{array}$ & $\begin{array}{c}0.007 \\
(0.010) \\
{[0.604]}\end{array}$ & $\begin{array}{r}-0.000 \\
(0.004) \\
{[0.954]}\end{array}$ \\
\hline Mean of outcome & 0.630 & 1.107 & 1.308 & 0.849 & 1.896 & 0.855 \\
\hline Population Density & Yes & Yes & Yes & Yes & Yes & Yes \\
\hline Individual Controls & Yes & Yes & Yes & Yes & Yes & Yes \\
\hline Geographic Controls & Yes & Yes & Yes & Yes & Yes & Yes \\
\hline Disease Controls & Yes & Yes & Yes & Yes & Yes & Yes \\
\hline Precolonial and Colonial Controls & Yes & Yes & Yes & Yes & Yes & Yes \\
\hline District FE & Yes & Yes & Yes & Yes & Yes & Yes \\
\hline Year FE & Yes & Yes & Yes & Yes & Yes & Yes \\
\hline Observations & 8,349 & 8,256 & 3,063 & 3,415 & 3,261 & 6,578 \\
\hline Clusters & 21 & 21 & 21 & 21 & 21 & 21 \\
\hline
\end{tabular}

Notes: Regressions estimated by OLS. Robust standard errors in parentheses clustered by colonial province. Wild cluster bootstrap (by district) p-values are in brackets. The unit of observation is an individual. Prisoners per 100,000 pop. are averages of long-term ( $>2$ years sentence) prisoners per 100,000 population (1939 pop.) over 1920 to 1938. Trust variables are from the Afrobarometer samples over 2003 to 2016 and as defined in the main text. Trust outcomes are reported trust levels on a scale of $0-3$, where "Not at all" = "0", "Just a little"="1", "Somewhat"="2", "A lot"="3". All regressions use district fixed effects at the current state level in Nigeria, year fixed effects, educational attainment fixed effects and controls for sub-district or local government area population density in 2006. Individual controls include age, age squared and gender. Geographic controls at the sub-district level include, ruggedness, indicators for petroleum, seacoast and mean land suitability for agriculture and mean elevation in alternate specifications. Disease controls at the sub-district level include malaria suitability and tse tse fly suitability in alternate specifications with results unchanged. Precolonial and colonial controls at the ethnicity-level include the level of precolonial centralization and total exports of slaves from the region during the Atlantic slave trade. ***Significant at the 1 percent level, ${ }^{* *}$ Significant at the 5 percent level, ${ }^{*}$ Significant at the 10 percent level. 
Table 10: First and second-state estimates for interacted instrument and effect of colonial imprisonment on trust in police (legal) and trust in relatives (interpersonal)

\begin{tabular}{|c|c|c|c|c|}
\hline & \multicolumn{4}{|c|}{ Panel B: Second-Stage 2SLS Estimates } \\
\hline & \multicolumn{2}{|c|}{ Trust in Police } & \multicolumn{2}{|c|}{ Trust in Relatives } \\
\hline & $(1)$ & $(2)$ & $(3)$ & $(4)$ \\
\hline Prisoners per 100,000 pop. & $\begin{array}{l}-0.021^{* * *} \\
(0.005)\end{array}$ & $\begin{array}{l}-0.022^{* * *} \\
(0.005)\end{array}$ & $\begin{array}{c}0.016 \\
(0.024)\end{array}$ & $\begin{array}{c}0.005 \\
(0.035)\end{array}$ \\
\hline & \multicolumn{4}{|c|}{ Panel A: First-Stage Estimates } \\
\hline $\begin{array}{l}\text { Soil Suitability for Palm Oil } \\
\text { x Colonial Palm Oil Production }\end{array}$ & $\begin{array}{l}0.191^{* * *} \\
(0.023)\end{array}$ & $\begin{array}{l}0.187^{* * *} \\
(0.040)\end{array}$ & $\begin{array}{l}0.214^{* * *} \\
(0.053)\end{array}$ & $\begin{array}{l}0.227^{* * *} \\
(0.045)\end{array}$ \\
\hline F-Stat of Excluded Instrument & 14.80 & 21.65 & 16.13 & 25.21 \\
\hline Population Density & Yes & Yes & Yes & Yes \\
\hline Individual Controls & Yes & Yes & Yes & Yes \\
\hline Geographic Controls & No & Yes & No & Yes \\
\hline Disease Controls & No & Yes & No & Yes \\
\hline Precolonial and Colonial Controls & No & Yes & No & Yes \\
\hline District FE & Yes & Yes & Yes & Yes \\
\hline Year FE & Yes & Yes & Yes & Yes \\
\hline Observations & 10,693 & 8,349 & 4,355 & 3,415 \\
\hline Clusters & 21 & 21 & 21 & 21 \\
\hline
\end{tabular}

Notes: Regressions estimated by OLS. Robust standard errors in parentheses clustered by colonial province. The unit of observation is an individual. Prisoners per 100,000 pop. are averages of long-term ( $>2$ years sentence) prisoners per 100,000 population (1939 pop.) over 1920 to 1938. Trust variables are from the Afrobarometer samples over 2003 to 2016 and as defined in the main text. Trust outcomes are reported trust levels on a scale of $0-3$, where "Not at all"= "0", "Just a little"="1", "Somewhat"="2", "A lot"="3". All regressions use district fixed effects at the current state level in Nigeria, year fixed effects, educational attainment fixed effects and controls for sub-district or local government area population density in 2006. Individual controls include age, age squared and gender. Geographic controls at the sub-district level include ruggedness, indicators for petroleum, seacoast and mean elevation in alternate specifications. Disease controls at the sub-district level include malaria suitability and tse tse fly suitability in alternate specifications with results unchanged. Precolonial and colonial controls at the ethnicity-level include the level of precolonial centralization and total exports of slaves from the region during the Atlantic slave trade. ${ }^{* * *}$ Significant at the 1 percent level, ${ }^{* *}$ Significant at the 5 percent level, *Significant at the 10 percent level. 


\section{References}

Abiodun, Tosin Funmi. 2017. A historical study on penal confinement and institutional life in southern Nigeria, 1860-1956 PhD thesis.

Acemoglu, Daron, and Alexander Wolitzky. 2011. "The economics of labor coercion." Econometrica 79 (2): 555-600.

Adamson, Christopher. 1984. "Toward a Marxian penology: Captive criminal populations as economic threats and resources." Social Problems 31 (4): 435-458.

Adjuik, M, M Bagayoko, F Binka, M Coetzee, J Cox, M Craig, U Deichman, F Don deSavigny, C Fraser, E Gouws et al. 1998. "Towards an atlas of malaria risk in Africa." First technical report of the Mapping Malaria Risk in Africa/Atlas du Risque de la Malaria en Afrique (MARA/ARMA) collaboration. Durban, MARA/ARMA.

Ahungwa, Gabriel T, Ueda Haruna, and Rakiya Y Abdusalam. 2014. "Trend analysis of the contribution of agriculture to the gross domestic product of Nigeria (1960-2012)." Journal of Agriculture and Veterinary Science 7 (1): 50-55.

Akurang-Parry, Kwabena Opare. 2000. "Colonial forced labor policies for road-building in southern Ghana and international anti-forced labor pressures, 1900-1940." African Economic History (28): 1-25.

Alexopoulou, Kleoniki, and Dácil Juif. 2017. "Colonial State Formation Without Integration: Tax Capacity and Labour Regimes in Portuguese Mozambique (1890s-1970s)." International Review of Social History 62 (2): 215-252.

Alsan, Marcella. 2015. "The effect of the tsetse fly on African development." American Economic Review 105 (1): 382-410. 
Amare, Mulubrhan, Nathaniel D Jensen, Bekele Shiferaw, and Jennifer Denno Cissé. 2018. "Rainfall shocks and agricultural productivity: Implication for rural household consumption." Agricultural systems 166: 79-89.

Anderson, David M. 2000. "Master and servant in colonial Kenya, 1895-1939." The Journal of African History 41 (3): 459-485.

Archibong, Belinda. 2019. "Explaining divergence in the long-term effects of precolonial centralization on access to public infrastructure services in Nigeria." World Development 121: $123-140$.

Ash, Catherine B. 2006. "Forced labor in colonial West Africa." History Compass 4 (3): 402-406.

Avio, Kenneth. 1998. "The economics of prisons." European Journal of Law and Economics $6(2): 143-175$.

Bair, Asatar. 2007. Prison Labor in the United States: an economic analysis. Routledge.

Becker, Gary S. 1968. "Crime and Punishment: An Economic Approach." Journal of Political Economy 76: 169-217.

Bernault, Florence. 2007. "The shadow of rule: Colonial power and modern punishment in Africa." Cultures of Confinement: A History of the Prison in Africa, Asia and Latin America pp. 55-94.

Bhuller, Manudeep, Gordon B Dahl, Katrine V Løken, and Magne Mogstad. 2020. "Incarceration, recidivism, and employment." Journal of Political Economy 128 (4): 000-000.

Bobonis, Gustavo J, and Peter M Morrow. 2014. "Labor coercion and the accumulation of human capital." Journal of Development Economics 108: 32-53. 
Branch, Daniel. 2005. "Imprisonment and colonialism in Kenya, c. 1930-1952: Escaping the carceral archipelago." The International journal of African historical studies 38 (2): 239-265.

Cameron, A Colin, Jonah B Gelbach, and Douglas L Miller. 2008. "Bootstrap-based improvements for inference with clustered errors." The Review of Economics and Statistics 90 (3): $414-427$.

Campbell, Jon. 2020. "New York's solution to hand sanitizer shortage: Prison labor, hourly wages below $\$ 1 . "$ USA Today .

Chapman, Isabelle. 2019. "Prison inmates are fighting California's fires, but are often denied firefighting jobs after their release." $C N N$.

Cooper, Frederick. 1996. Decolonization and African society: The labor question in French and British Africa. Vol. 89 Cambridge University Press.

Cox, Robynn. 2010. "Crime, incarceration, and employment in light of the great recession." The Review of Black Political Economy 37 (3-4): 283-294.

Dell, Melissa. 2010. "The persistent effects of Peru's mining mita." Econometrica 78 (6): 1863-1903.

Dillon, Andrew, Kevin McGee, and Gbemisola Oseni. 2015. "Agricultural production, dietary diversity and climate variability." The Journal of Development Studies 51 (8): 976-995.

Doston, John, and Teresa Vanfleet. 2014. "Prison Labor Exports from China and Implications for U.S. Policy." US-China Economic and Security Review Commission Staff Research Report .

Dube, Oeindrila, and Juan F Vargas. 2013. "Commodity price shocks and civil conflict: Evidence from Colombia." The Review of Economic Studies 80 (4): 1384-1421. 
Ekechi, Felix K. 1989. Tradition and transformation in Eastern Nigeria: a sociopolitical history of Owerri and its hinterland, 1902-1947. Kent State Univ Pr.

Feinstein, Charles Hilliard. 1972. National income, expenditure and output of the United Kingdom, 1855-1965. Vol. 6 Cambridge University Press Cambridge.

Foreign, British, and Commonwealth Office. 1947. "Nigeria Annual Report on the Treatment of Offenders, 1947.".

Foreign, British, and Commonwealth Office. 1960. "Nigeria Annual Report on the Prisons Department, North and South Provinces 1914-1960.”.

Frankema, Ewout. 2011. "Colonial taxation and government spending in British Africa, 1880-1940: Maximizing revenue or minimizing effort?" Explorations in Economic History 48 (1): 136-149.

Frankema, Ewout, Jeffrey Williamson, and Pieter Woltjer. 2018. "An economic rationale for the West African scramble? The commercial transition and the commodity price boom of 1835-1885." The Journal of Economic History 78 (1): 231-267.

Frankema, Ewout, and Marlous Van Waijenburg. 2012. "Structural impediments to African growth? New evidence from real wages in British Africa, 1880-1965." The Journal of Economic History 72 (4): 895-926.

Freeman, Richard B. 1999. "The economics of crime." Handbook of labor economics 3: 35293571.

Freund, Bill. 1984. "Labor and labor history in Africa: A review of the literature." African Studies Review 27 (2): 1-58.

Gallup, John Luke, and Jeffrey D Sachs. 2001. "The economic burden of malaria." The American journal of tropical medicine and hygiene 64 (1 suppl): 85-96. 
Gardner, Leigh. 2012. Taxing colonial Africa: the political economy of British imperialism. Oxford University Press.

Gregory, Paul R, and Valery Lazarev. 2013. The economics of forced labor: The Soviet Gulag. Vol. 518 Hoover Institution Press.

Grubb, Farley. 2000. "The transatlantic market for British convict labor." The Journal of Economic History 60 (1): 94-122.

Grubb, Farley. 2001. "The market evaluation of criminality: evidence from the auction of British convict labor in America, 1767-1775." American Economic Review 91 (1): 295-304.

Harris, John H. 1914. "Making the Lazy Nigger Work." Contemporary Review 105: 819-25.

Hochschild, Adam. 1999. King Leopold's ghost: A story of greed, terror, and heroism in colonial Africa. Houghton Mifflin Harcourt.

Hynd, Stacey. 2015. ““....a Weapon of Immense Vallue?” Convict Labour in British Colonial Africa, c. 1850-1950s, in Christian G. de Vito, Alex Lichtenstein (eds), Global Convict Labour, Leiden, Brill, Studies in Global Social History, vol. 19, 2015, p. 222-248.”.

Jacobson, Jessica, Catherine Heard, and Helen Fair. 2017. "Prison: Evidence of its use and over-use from around the world.".

Jensen, Robert. 2000. "Agricultural volatility and investments in children." American Economic Review 90 (2): 399-404.

Juif, Dácil, and Ewout Frankema. 2018. "From coercion to compensation: institutional responses to labour scarcity in the Central African Copperbelt." Journal of Institutional Economics 14 (2): 313-343. 
Katz, Lawrence, Steven D Levitt, and Ellen Shustorovich. 2003. "Prison conditions, capital punishment, and deterrence." American Law and Economics Review 5 (2): 318-343.

Kaur, Supreet. 2019. "Nominal wage rigidity in village labor markets." American Economic Review 109 (10): 3585-3616.

Killingray, David. 1989. "Labour Exploitation for Military Campaigns in British Colonial Africa 1870-1945." Journal of Contemporary History 24 (3): 483-501.

Killingray, David. 1999. "8. Punishment to Fit the Crime? Penal Policy and Practice in British Colonial Africa." In Enfermement, prison et châtiments en Afrique. Editions Karthala pp. 181-203.

Kingdon, Donald. 1923. The laws of Nigeria, containing the ordinances of Nigeria, in force on the 1st day of January, 1923: and the orders, proclamations, rules, regulations and bye-laws made thereunder, in force on the 1st day of May, 1923, and the principal imperial statutes, orders in Council, letters patent and royal instructions relating to Nigeria. Rev. ed. / prepared under the authority of the revised edition of the laws ordinance, 1923 ; by donald kingdon. ed. Govt. Printer Lagos.

Knack, Stephen, and Philip Keefer. 1997. "Does social capital have an economic payoff? A cross-country investigation." The Quarterly Journal of Economics 112 (4): 1251-1288.

Kunkel, Sarah. 2018. "Forced Labour, Roads, and Chiefs: The Implementation of the ILO Forced Labour Convention in the Gold Coast." International Review of Social History pp. $1-28$.

Lesk, Corey, Pedram Rowhani, and Navin Ramankutty. 2016. "Influence of extreme weather disasters on global crop production." Nature 529 (7584): 84. 
Lowes, Sara, and Eduardo Montero. 2016. "Concessions, Violence, and Indirect Rule: Evidence from the Congo Free State." Working paper, $R$ and $R$ at Quarterly Journal of Economics .

Lowes, Sara Rachel, and Eduardo Montero. 2018. "The legacy of colonial medicine in Central Africa." CEPR Discussion Paper No. DP12772, $R$ and $R$ at American Economic Review.

Maul, Daniel Roger. 2007. "The International Labour Organization and the struggle against forced labour from 1919 to the present." Labor History 48 (4): 477-500.

Muller, Christopher. 2012. "Northward migration and the rise of racial disparity in American incarceration, 1880-1950." American Journal of Sociology 118 (2): 281-326.

Naidu, Suresh, and Noam Yuchtman. 2013. "Coercive Contract Enforcement: Law and the Labor Market in Nineteenth Century Industrial Britain." The American Economic Review 103 (1): 107-144.

Nunn, Nathan. 2008. "The Long-term Effects of Africa's Slave Trades." The Quarterly Journal of Economics 123 (1): 139-176.

Nunn, Nathan, and Leonard Wantchekon. 2011. "The slave trade and the origins of mistrust in Africa." The American Economic Review 101 (7): 3221-3252.

O'Flaherty, Brendan, and Rajiv Sethi. 2019. Shadows of Doubt: Stereotypes, Crime, and the Pursuit of Justice. Harvard University Press.

Ofonagoro, Walter I. 1982. "An aspect of British colonial policy in southern Nigeria: The problems of forced labour and slavery, 1895-1928." Studies in southern Nigerian history pp. 219-44.

Okia, Opolot. 2012. Communal Labor in Colonial Kenya: The Legitimization of Coercion, 1912-1930. Springer. 
Okoye, Dozie, Roland Pongou, and Tite Yokossi. 2019. "New technology, better economy? The heterogeneous impact of colonial railroads in Nigeria." Journal of Development Economics 140: 320-354.

Papaioannou, Kostadis J, and Michiel de Haas. 2017. "Weather Shocks and Agricultural Commercialization in Colonial Tropical Africa: Did Cash Crops Alleviate Social Distress?" World Development 94: 346-365.

Poyker, Michael. 2019. "Economic Consequences of the US Convict Labor System.” Institute for New Economic Thinking Working Paper Series (91).

Report, Nigeria Annual. 1925. "Nigeria Annual Report on the Prisons Department 19251935.".

Rohner, Dominic, Mathias Thoenig, and Fabrizio Zilibotti. 2013. "War signals: A theory of trade, trust, and conflict." Review of Economic Studies 80 (3): 1114-1147.

Salau, Mohammed Bashir. 2015. "10. Convict labour in early colonial Northern Nigeria: a preliminary study." From Dust to Digital: Ten Years of the Endangered Archives Programme p. 293.

Saleh-Hanna, Viviane. 2017. Colonial systems of control: Criminal justice in Nigeria. University of Ottawa Press/Les Presses de l?Université d?Ottawa.

Saleh, Mohamed. 2019. "Export Booms and Labor Coercion: Evidence from the Lancashire Cotton Famine.".

Sarsons, Heather. 2015. "Rainfall and conflict: A cautionary tale." Journal of development Economics 115: 62-72.

Sherman, Lawrence W. 2015. "Trust and confidence in criminal justice." National Institute of Justice Journal 248: 22-31. 
Thomas, Roger G. 1973. "Forced labour in British West Africa: the case of the Northern Territories of the Gold Coast 1906-1927." The Journal of African History 14 (1): 79-103.

Travis, Jeremy, Bruce Western, and F Stevens Redburn. 2014. The growth of incarceration in the United States: Exploring causes and consequences. The National Academies Press.

Trevor, Daphne. 1936. "South African Native Taxation." The Review of Economic Studies 3 (3): $217-225$.

van Waijenburg, Marlous. 2018. "Financing the African Colonial State: The Revenue Imperative and Forced Labor." The Journal of Economic History 78 (1): 40-80.

Wiemers, Alice. 2017. "When the Chief Takes an Interest: Development and the Reinvention OF 'Communal' Labor in Northern Ghana, 1935-60." The Journal of African History 58 (2): $239-257$. 


\section{A Appendix (For Online Publication)}

\section{Contents}

1 Introduction $\quad 2$

2 Prison Labor in Colonial Africa $r$

2.1 A History of Forced Labor . . . . . . . . . . . . . . . . . . . . . . . 8

2.2 Prison Labor in Colonial Africa . . . . . . . . . . . . . . . . . . . . 10

2.3 Prison Labor in British Colonial Nigeria . . . . . . . . . . . . . . . 11

3 Estimating the Value of Prison Labor $\quad 16$

3.1 Historical Data . . . . . . . . . . . . . . . . . 16

3.2 Empirical Strategy . . . . . . . . . . . . . . . . . . . . 17

3.3 Value of Prison Labor Results . . . . . . . . . . . . . . . . . . . . . . . 19

3.3.1 Comparing Imputed Estimates of the Value of Prison Labor to Reported Colonial Estimates . . . . . . . . . . . . . . . 20

4 The Effects of Economic Shocks on Incarceration Rates and the Use of $\begin{array}{ll}\text { Prison Labor } & 22\end{array}$

4.1 Data on Incarceration Rates and Economic Shocks . . . . . . . . . . . . 22

4.2 Summary Statistics . . . . . . . . . . . . . . . . . . . 23

4.3 Estimating Equations . . . . . . . . . . . . . . . . 25

4.3.1 Nonlinear Effects of Economic Shocks on Incarceration Rates . . . . . 25

4.3.2 Identifying the Effects of Positive Rainfall Shocks on Incarceration Rates 27

4.3.3 Effects of Cash Crop Price Shocks on Colonial Incarceration Rates . . 29

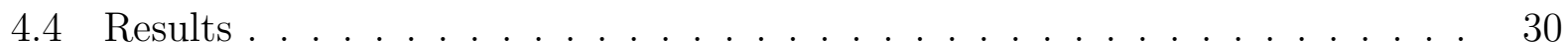

4.4.1 Nonlinear Effects of Economic Shocks on Incarceration Rates Results 30 
4.4.2 Identifying the Effects of Positive Rainfall Shocks on Incarceration Rates Results . . . . . . . . . . . . . . . . . . . 32

4.4.3 Effects of Cash Crop Price Shocks on Colonial Incarceration Rates Results . . . . . . . . . . . . . . . . . . . 34

4.4.4 Railroad, Wages and Incarceration Rates . . . . . . . . . . . . 34

5 Discussion: Colonial Imprisonment and Contemporary Trust in Legal Institutions

$\begin{array}{llr}6 & \text { Conclusion } & 39\end{array}$

$\begin{array}{lr}\text { A Appendix (For Online Publication) } & 68\end{array}$

A.1 Data and Archival Materials . . . . . . . . . . . . . . . 72

A.2 A Further History of Forced and Prison Labor in Colonial Africa . . . . . . . 73

A.3 North-South Differences in the Distribution of Colonial versus Native Prisons 78

A.4 Value of Prison Labor: Adjusting for Inflation . . . . . . . . . . . . 81

A.4.1 Value of Prison Labor: Measuring Bias in Estimates . . . . . . . . . 84

A.5 Relationship between Colonial Imprisonment and Trust in Colonial Institutions versus Interpersonal trust $\ldots \ldots \ldots \ldots$. . . . . . . . . . 85

\section{List of Figures}

1 Top 40 countries/territories for incarceration rates, 2018 with Nigeria incarceration rates in red (year 1940) and blue (year 2018). Source: World Prison

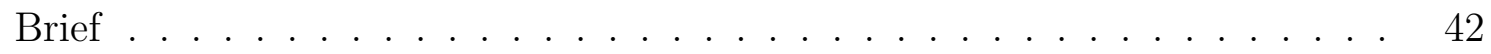

2 Punishment of convicts by race under Masters and Servants Ordinance in Kenya, 1931 and 1938. Source: Anderson (2000) . . . . . . . . . . . 43 
3 Share of total convictions in colonial courts and share of total prison admissions in postcolonial period by crime in Nigeria, 1920-1993. Source: see text 43

4 Composition of tax revenue in Nigeria, 1930-1980 . . . . . . . . . . . . . 44

5 Example of archival data on prisons and wages from the British Blue Books

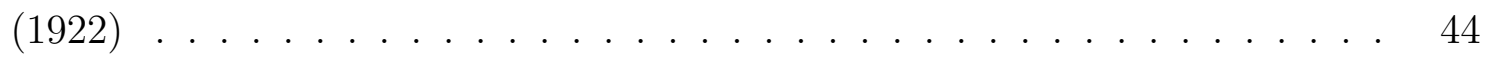

6 Nigeria provinces with colonial prison locations and railroad network shown (left) and regions (right) . . . . . . . . . . . . . . . 45

7 Wages, prisoner costs and daily average number in prisons in colonial Nigeria,

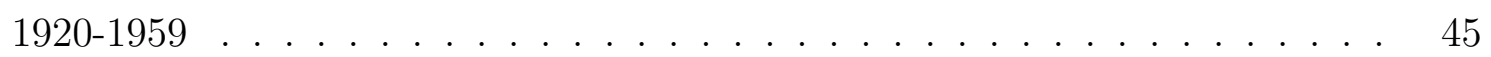

8 Relative value of prison labor, 1920-1959 . . . . . . . . . . . 46

$9 \quad$ Value of wages for different skill categories in prison and market sectors, 1919-

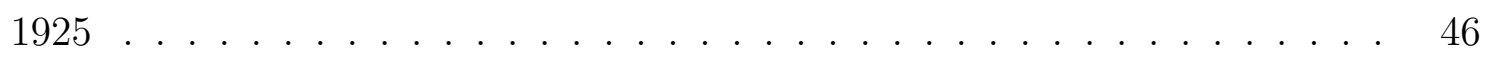

10 Mean number of prisoners per 100,000 population, 1920-1995 . . . . . . . . 47

11 Prison populations in colonial (1920) and postcolonial (1980) Nigeria . . . . 47

12 Prisoners and agricultural commodity prices, 1920-1995, Nigeria . . . . . . . 49

13 Agricultural commodity production in colonial Nigeria . . . . . . . . . . . 49

A1 African laborers on a railroad c. 1930, Source: Alexander Keese, CEAUP, Porto 72

A2 Breakdown of estimated public works expenditure, Northern (NP) and Southern (SP) Provinces, 1920 and 1935 . . . . . . . . . . . . . . 77

A3 Native administration prisons, $1940 \ldots \ldots \ldots$

A4 Native prison incarceration rates, 1940 and 1945 . . . . . . . . . . . 80

A5 Value of prison labor, real vs nominal estimates . . . . . . . . . . . 81

A6 Alternate prison and value of labor coercion measures, 1920-1938 . . . . . 85

\section{List of Tables}

1 Summary Statistics: Economic shocks and incarceration rates . . . . . . . 48 
2 Rainfall shocks and colonial (1920-1938) and postcolonial (1971-1995) incarceration rates . . . . . . . . . . . . . . . . . 50

3 Rainfall shocks and colonial (1920-1938) and postcolonial (1971-1995) incarceration rates by region . . . . . . . . . . . . . . . . . . 51

4 Rainfall shocks (by type) and colonial (1920-1938) and postcolonial (19711995) incarceration rates breakdown . . . . . . . . . . . . . . . . 52

$5 \quad$ Rainfall shocks and colonial (1920-1938) and postcolonial (1971-1995) incarceration rates by region . . . . . . . . . . . . . . . 5 53

6 Rainfall shocks (by type) and colonial (1920-1938) incarceration rates by custody/awaiting trial category . . . . . . . . . . . . . 54

7 Agricultural commodity prices and colonial incarceration rates . . . . . . . 55

8 Effect of wages and distance to railroad on colonial incarceration rates . . . . 56

9 OLS Estimates: Relationship between colonial imprisonment and present-day trust in historical legal Institutions versus interpersonal trust . . . . . . . . . 57

10 First and second-state estimates for interacted instrument and effect of colonial imprisonment on trust in police (legal) and trust in relatives (interpersonal) 58

A1 Relationship between precolonial centralization and number of colonial vs native prisons . . . . . . . . . . . . . . . . . . . . 80

A2 Value of prison labor, 1920-1959 . . . . . . . . . . . . . 82

A3 Value of prison labor, real estimates . . . . . . . . . . . . . 83

A4 Summary Statistics: Afrobarometer Results . . . . . . . . . . . . . 88

A5 Falsification Test: OLS Estimates of relationship between postcolonial imprisonment and present-day trust in historical legal Institutions versus interpersonal trust . . . . . . . . . . . . . . . . . . . .

A6 OLS Estimates: Relationship between colonial and postcolonial imprisonment and present-day crime outcomes . . . . . . . . . . . . . . . 90 
A7 IV Estimates: Effect of relationship between colonial imprisonment and presentday trust in historical legal Institutions versus interpersonal trust . . . . . . 91

\section{A.1 Data and Archival Materials}

- Primary data from British Online Archives, Nigeria [Colony and Protectorate] Blue Book, 1914-1940. British Foreign and Commonwealth Office

- Nigeria, Annual Report on the Prisons Department, Northern and Southern Provinces, $1914-1960$

- NAI, CSO 26/2 09591 Vol.1 'Lieutenant Governor Southern Province to Resident Calabar Province: Memorandum on Prison labor' 23rd April 1923

- Annual Report on the Treatment of Offenders, 1947, Nigeria

- Nigeria Annual Abstract of Statistics, 1975-1997

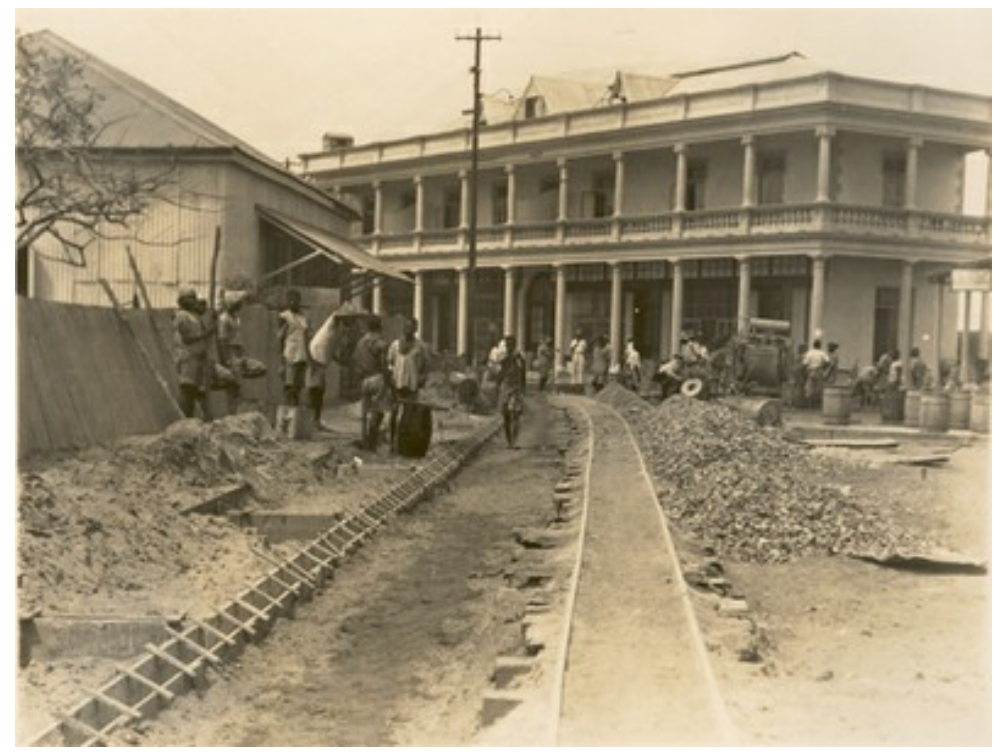

Figure A1: African laborers on a railroad c. 1930, Source: Alexander Keese, CEAUP, Porto 


\section{A.2 A Further History of Forced and Prison Labor in Colonial Africa}

Prison labor was a small part of a larger regime of domestic forced labor in colonial Africa. A small but rich and growing labor history of colonial Africa has documented the ways in which the so-called "revenue imperative" of colonial governments, whose objectives were to maximize revenue extraction while minimizing costs of administration in Africa, led to the establishment of coercive labor contracts in the region (Freund, 1984; Maul, 2007; Okia, 2012; Gardner, 2012; Cooper, 1996; Harris, 1914; Trevor, 1936; van Waijenburg, 2018; Alexopoulou and Juif, 2017). Following the signing of the Final Act of Congress of Vienna in 1815 to abolish slavery, a series of contentious debates about the nature of forced labor, and particularly the extent to which forced labor could be employed to fulfill the revenue demands in Europe's African colonies continued through the middle of the 20th century (Maul, 2007). The debates highlighted a number of responses to Europe's so-called "Africa labor question", where, faced with the realities of labor scarcity, increased demand for labor from both private and public sector employers and an indigenous labor force with their own preferences for work, the discussions shifted from questions about how to institute European systems of wage labor and private property ownership in the colonies to the amount of coercion a "civilized government" could use (Cooper, 1996).

Faced with these options - low pay for often dangerous, back-breaking work on railroads or in mines, under sometimes racist ${ }^{33}$, difficult employers - many Africans preferred selfemployment in subsistence farming to working in the colonial wage labor market (Frankema and Van Waijenburg, 2012; Harris, 1914). To address these constraints, colonial governments enacted a series of strategies to meet labor and revenue demands. Among these strategies

\footnotetext{
${ }^{33}$ Harris (1914) reports of the comments of a white employer, Mr E Tarlton in Kenya who, in complaining about labor shortages he faced, told the 1912 labor Commission in the East Africa Protectorate that "this is my busiest season and my work is entirely upset, and it is hardly surprising if I am in a red-hot state bordering on a desire to murder everyone with a black skin who comes within sight", p. 821.
} 
included the use of direct taxation like hut and poll taxes requiring cash payment to press Africans into the wage labor market, the use of labor tax legislation to force Africans to donate a certain number of hours of often unpaid labor to private and public sector work, and the use of precolonial communal labor requirements to compel Africans, under the direction of the chiefs, to provide unpaid labor for private and public works projects (Okia, 2012; Harris, 1914; Trevor, 1936; van Waijenburg, 2018; Cooper, 1996).

In colonial Nigeria, forced labor regulation included the Native House Rule Ordinance of 1901 and the Roads and Creek Proclamation of 1903, both of which mandated labor for 'public purposes' for all men between 15 and 50 years old and all women between 15 and 45 years old (Ofonagoro, 1982). The Masters and Servants Proclamations of 1901 and 1903 also instituted forced labor in colonial Nigeria, granting Native Administrators or chiefs the authority to coerce local laborers for up to 24 working days in a year or 1 out of 12 months. Laborers were frequently employed on public works projects and physically intensive manual tasks like porterage, carrying pounds of baggage for British officials through often dangerous environments like military expeditions for "miserable" below market-wage pay (Ofonagoro, 1982; Okia, 2012).

Following a series of forced labor scandals, one of which was the sanctioning of torture, mutilation and murder of millions of Congolese for the rubber extraction trade under Belgium's King Leopold through the 1890s, another debate on the labor question led to the passing of the Slavery Convention by the League of Nations in 1926 (Hochschild, 1999; Lowes and Montero, 2016). The Convention urged European powers to abolish slavery "in all its forms" and the League requested that the International Labor Organization (ILO) investigate the "best means of preventing forced or compulsory labor from developing into conditions analogous to slavery" (Cooper, 1996). p. 29. These exchanges led to the passing of the Forced Labor Convention at the 1930 ILO conference which forbade the use of forced 
labor for private industry where forced labor was defined as "all work or service which is extracted from any person under the menace of any penalty and for which the said person has not offered himself voluntarily" (Cooper, 1996). p. 2934. The Convention made exceptions for the use of forced labor for public works, "penal and communal labor in the public sector and compulsory military service' (Kunkel, 2018; Killingray, 1989).

While Britain was the first to sign the ILO article, followed by France and a few other European governments in the mid 20th century, it, and its colonial peers continued, and in some cases intensified forced labor practices through the use of 'unofficial' communal labor for public works projects (Kunkel, 2018). The practice is exemplified in a 1944 statement made by the then district commissioner of Northern Ghana's Builsa district, who, in showing the chief commissioner of the Northern territories the new projects the colonial government had started funding in the region over the past years, among which were schools, rural roads, bridges and dams, argued for the financial viability of the district by informing the commissioner that the chief had supplied the government with unpaid communal labor: "nearly all the labourers I find whom your Honour saw working in the new Sandema dam are 'voluntary' workers, there are only seven names on the time sheet which is encouraging." (Wiemers, 2017), p.239. Many of these coercive labor practices continued through the end of the 1930s and as late as the 1950s in some regions, when African workers began to actively organize labor unions and strikes to protest labor contracts with fixed low wages amidst rising food prices in the mid to late part of the 1930s after the Depression (Cooper, 1996). Among the most famous strikes were the 1935 Copperbelt strike of African miners in Northern Rhodesia, the Mombasa general strike, the Dar es Salam dock strike and a number of strikes on the railways of the Gold Coast in 1939 (Cooper, 1996).

In Nigeria, although prisoners were most often employed on public works, public works

\footnotetext{
${ }^{34}$ ILO 29, Article 2 s 2a, c, e, Articles 4 and 5
} 
expenditure was a small fraction of overall colonial expenditures between 1920 and 1940, composing an average of $2.8 \%$ of colonial expenditures over the period ${ }^{35}$. As of $1920,30 \%$ of expenditure was on railways, $12 \%$ on servicing public debt, and $19 \%$ of expenditure was devoted to defense spending on 'marine, political and West African Frontier Force'. The majority of revenues in 1920 were from customs (46\%) and railways (23\%). By 1936, the share of expenditure on railways had dropped to $8 \%$ of overall expenditure, with public debt, and pensions and gratuities remaining as the top spending categories for the colonial regime. Public works expenditure in both years remained low at around $2 \%$. While revenue from the railway could be used to service railroad expenditure, only $2.8 \%$ of colonial expenditures, on average, was allocated for less costly public works projects, like spending on civil roads, canals, bridges and "buildings not of a military nature" (e.g. court houses and hospitals). A breakdown of the top ten, where available, categories for estimated public works expenditure in 1920 and 1935 for the Northern and Southern provinces is shown in Figure A2 $2^{36}$. In the Northern provinces in 1920, roads, public offices, hospitals and court houses accounted for $80 \%$ of overall public works expenditure, while government quarters, industrial plants and roads accounted for $68 \%$ of overall public works expenditure in Southern provinces in the same year. By 1935, the major public works expenditure categories in both the Northern and Southern provinces were waterworks, electricity infrastructure projects and government offices with $100 \%$ and $95 \%$ of overall public works expenditure in Northern and Southern Provinces respectively. Convict labor, by colonial officials' own admissions, was an essential part of funding these public works projects (Foreign and Office, 1960).

\footnotetext{
${ }^{35}$ Author's estimates from Annual Report on Prisons Data over 1920 to 1940.

${ }^{36}$ We use estimated rather than actual expenditure in a given year to reflect colonial government expectation around expenditure and to account for unfinished projects and multiple missing entries in the 'spending to date' values provided in the Blue Books records.
} 

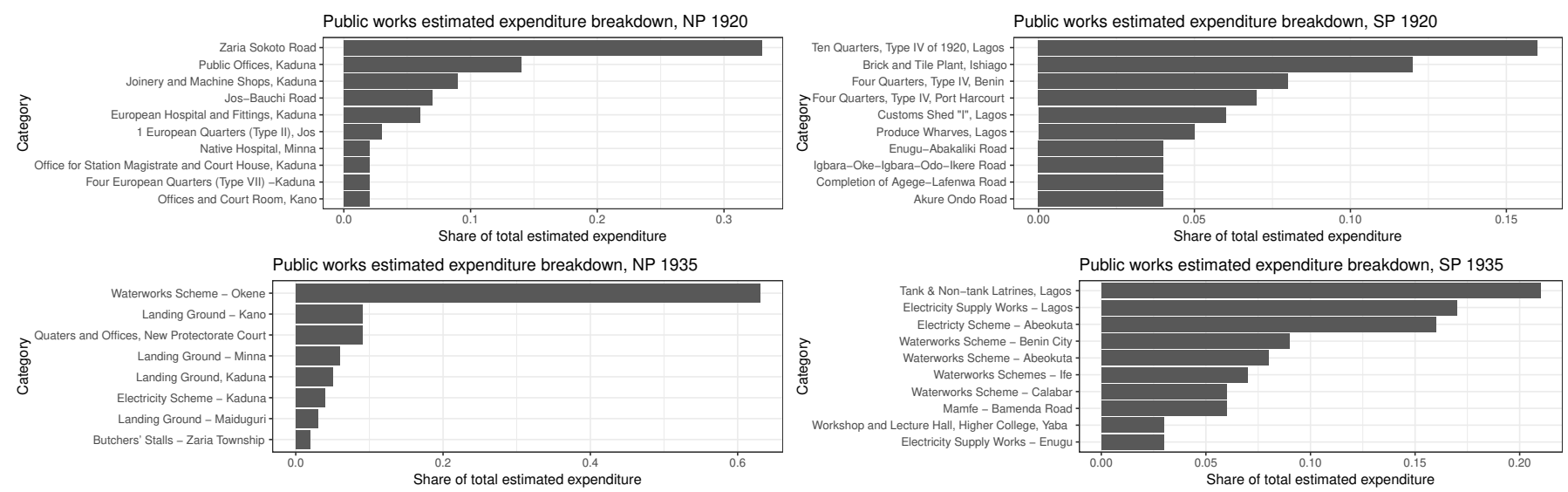

Figure A2: Breakdown of estimated public works expenditure, Northern (NP) and Southern (SP) Provinces, 1920 and 1935 


\section{A.3 North-South Differences in the Distribution of Colonial versus Native Pris- ons}

There was a dual system of prison administration in Nigeria, under the Native Administration, overseen by local chiefs under indirect rule. Under indirect rule, areas with more centralized precolonial institutions were granted more autonomy to oversee local administration, including on the creation and administering of Native Authority prisons. Results from Table A1 confirm a significant positive correlation between the level of precolonial centralization and the numbers of native prisons (Archibong, 2019). Although we don't have detailed Native Administration prisons data over the 1920 to 1938 period, Figure A3 shows the distribution of Native Administration prisons in 1940, for the first year of available data in the colonial archives.

Native Authority or Administration prisons were more heavily concentrated in the Northern provinces, which had a more extensive history of organized precolonial institutions around courts than their southern counterparts (Killingray, 1999). Precolonial political institutions are proxied using Murdock's (1967) "Jurisdictional Hierarchy Beyond the Local Community Level" called the precolonial centralization index here. The precolonial centralization index or "Jurisdictional Hierarchy Beyond the Local Community Level" variable is an index of "political complexity" that assigns a score between 0 to 4 to each ethnic region unit and describes the number of political jurisdictional hierarchies above the local community level for each unit. The score is defined as follows: 0 represents so-called "stateless societies","lacking any form of political organization", 1 and 2 are petty and larger paramount chiefdoms, 3 and 4 are large, more organized states. Table A1 provides suggestive evidence of the positive correlation between precolonial centralization and the number of native prisons in a colonial province. While prison labor was a feature of all colonial era prisons, both Native Administration and colonial government prisons, since Native Authority prisons were 
more numerous than colonial prisons ${ }^{37}$, Native Authority prisons processed more prisoners than colonial prisons in the north, with the share of prison labor coming primarily from Native Authority prisons in the Northern provinces.

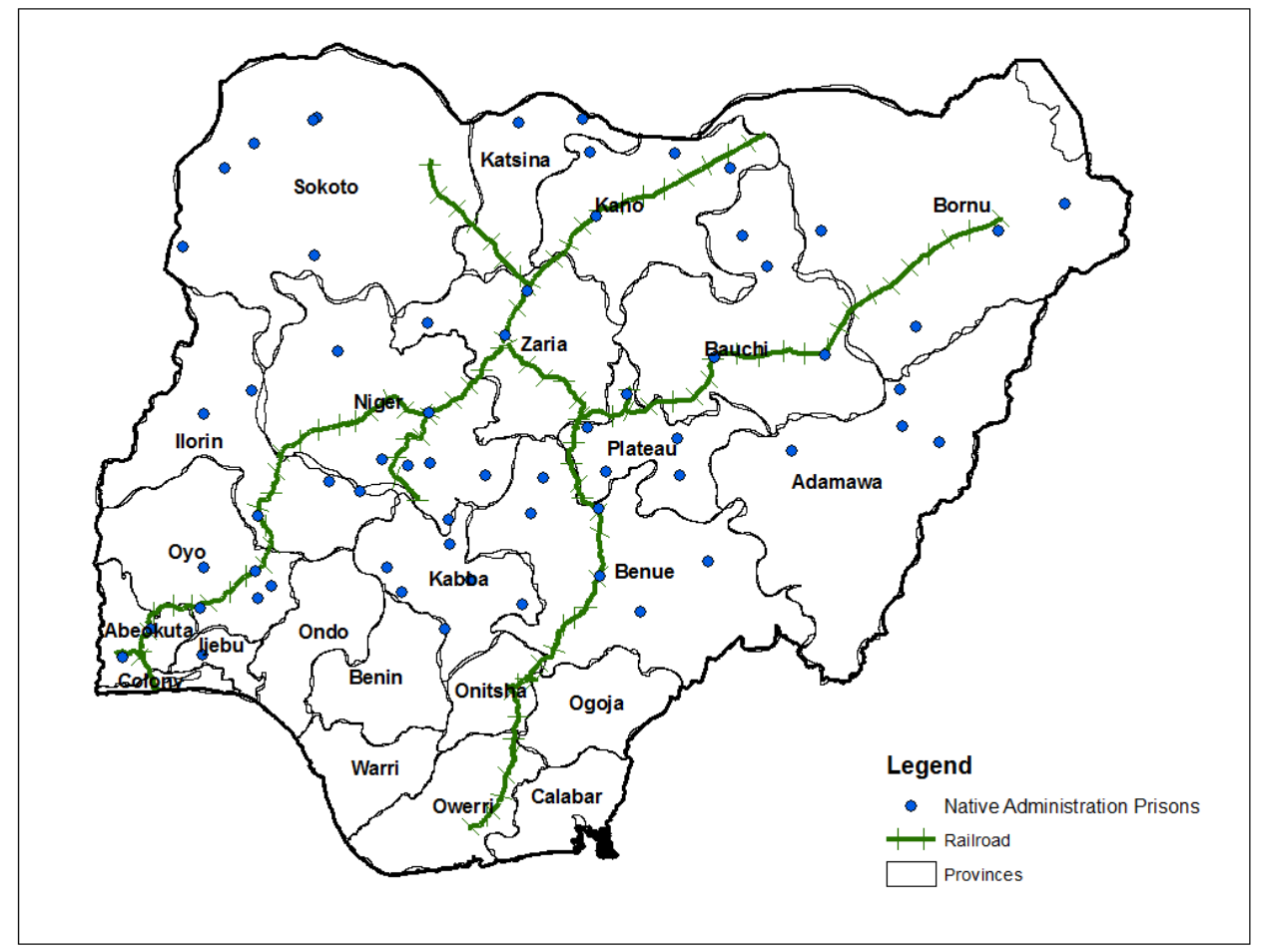

Figure A3: Native administration prisons, 1940

\footnotetext{
${ }^{37}$ On average there were 18 colonial prisons over 1920 to 1938 in the Northern provinces vs 56 Native Authority prisons in 1940. The ratio for Southern provinces over those periods was 54 to 9 . Source: colonial archives.
} 
Table A1: Relationship between precolonial centralization and number of colonial vs native prisons

\begin{tabular}{lcc}
\hline \hline & Native prisons & Colonial prisons \\
& $(1)$ & $(2)$ \\
\hline Precolonial centralization & $0.599^{*}$ & 0.515 \\
& $(0.316)$ & $(0.339)$ \\
Constant & $1.447^{* * *}$ & $2.112^{* *}$ \\
Observations & $(0.265)$ & $(0.969)$ \\
$\mathrm{R}^{2}$ & 22 & 19 \\
\hline \hline
\end{tabular}

Notes: Regressions estimated by OLS. Robust standard errors in parentheses. Unit of observation is Murdock ethnic region. Precolonial centralization is Murdock centralization index as defined in text.

${ }^{* * *}$ Significant at the 1 percent level, ${ }^{* *}$ Significant at the 5 percent level, * Significant at the 10 percent level.
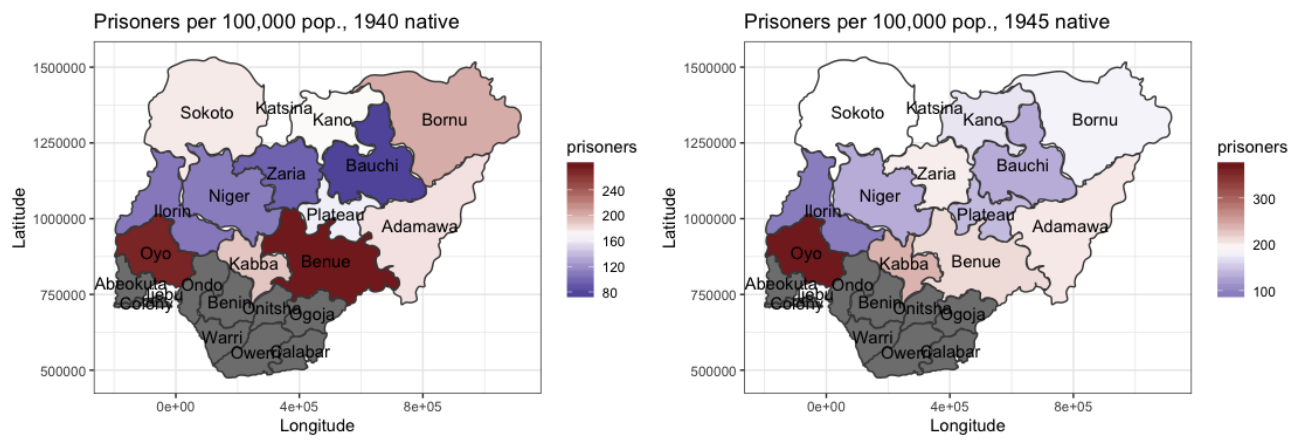

Figure A4: Native prison incarceration rates, 1940 and 1945 


\section{A.4 Value of Prison Labor: Adjusting for Inflation}

The measures of values of prison labor used so far have been calculated using nominal values as shown in Figure A5(a) and Table A2. One potential side effect of using nominal values when observing trends over time is that is it difficult disentangle the difference between changes in the observed variable and changes in the price level. To ensure that the trends in our measure of prison labor are not driven by changes in the price level, we convert the values into real values using 1920 as the base year, following the technique outlined in Frankema $(2011)^{38}$. Figure A5(b) and Table A3 show trends in the value of prison labor, adjusted for inflation. The trends remain unchanged using real versus nominal estimates of prison labor and the value of prison labor is not driven by changes in the price level.
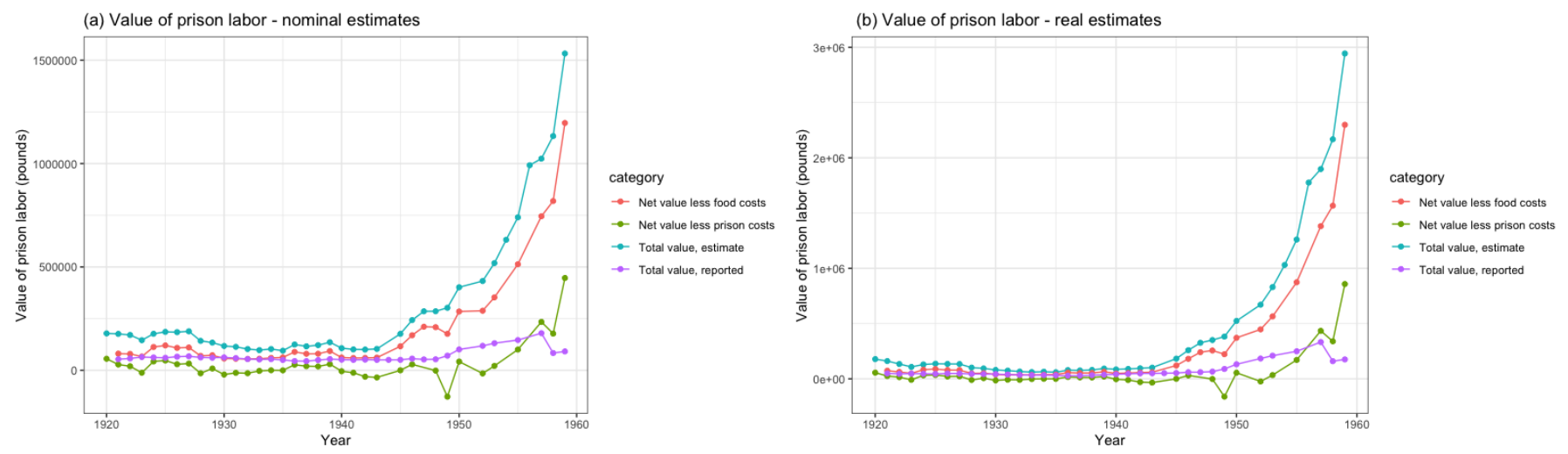

Figure A5: Value of prison labor, real vs nominal estimates

\footnotetext{
${ }^{38}$ Using Feinstein (1972)'s British price index data.
} 
Table A2: Value of prison labor, 1920-1959

\begin{tabular}{|c|c|c|c|c|c|c|c|}
\hline Year & $\begin{array}{l}\text { Total value of } \\
\text { prison labor }(\mathrm{PL}) \text {, } \\
\text { estimate }\end{array}$ & $\begin{array}{l}\text { Net value of PL- } \\
\text { less food costs }\end{array}$ & $\begin{array}{l}\text { Net value of PL- } \\
\text { less prison costs }\end{array}$ & $\begin{array}{l}\text { Total value of } \mathrm{PL} \text {, } \\
\text { reported }\end{array}$ & $\begin{array}{l}\text { Share of total PL } \\
\text { value in public } \\
\text { works exp. }\end{array}$ & $\begin{array}{l}\text { Share of net PL } \\
\text { value (food) in pub- } \\
\text { lic works exp. }\end{array}$ & $\begin{array}{l}\text { Share of net PL } \\
\text { value (prison) in } \\
\text { public works exp. }\end{array}$ \\
\hline 1920 & $178,498.10$ & & $55,889.37$ & & 1.33 & & 0.42 \\
\hline 1921 & $176,260.50$ & $80,740.86$ & $27,912.67$ & 53,661 & 1.12 & 0.51 & 0.18 \\
\hline 1922 & $170,936.80$ & $79,406.14$ & $19,618.41$ & 57,312 & & & \\
\hline 1923 & $145,679.00$ & $66,501.46$ & -11905.93 & 64,244 & 0.93 & 0.43 & -0.08 \\
\hline 1924 & $176,716.20$ & $112,860.10$ & $42,908.14$ & 62,222 & 1.13 & 0.72 & 0.27 \\
\hline 1925 & $185,745.60$ & $120,236.40$ & $47,427.82$ & 60,492 & 1.17 & 0.76 & 0.30 \\
\hline 1926 & $184,522.30$ & $108,556.80$ & $29,269.52$ & 66,052 & 1.05 & 0.62 & 0.17 \\
\hline 1927 & $188,665.80$ & $110,374.10$ & $32,701.03$ & 67,859 & 1.02 & 0.59 & 0.18 \\
\hline 1928 & $142,465.90$ & $69,713.27$ & $-14,449.62$ & 62,358 & 0.71 & 0.35 & -0.07 \\
\hline 1929 & $134,080.40$ & $73,090.61$ & $8,683.13$ & 60,851 & 0.61 & 0.33 & 0.04 \\
\hline 1930 & $117,659.00$ & $57,097.79$ & $-20,521.35$ & 62,408 & 0.48 & 0.23 & -0.08 \\
\hline 1931 & $113,460.70$ & $55,957.54$ & $-12,285.62$ & 59,090 & 0.44 & 0.22 & -0.05 \\
\hline 1932 & $102,978.70$ & $54,870.35$ & $-14,204.48$ & 54,415 & 0.41 & 0.22 & -0.06 \\
\hline 1933 & $97,714.65$ & $55,956.14$ & $-2,798.60$ & 52,434 & 0.53 & 0.31 & -0.02 \\
\hline 1934 & $102,992.10$ & $59,841.23$ & 133.75 & 53,956 & 0.69 & 0.40 & 0.001 \\
\hline 1935 & $94,803.18$ & $62,325.81$ & -343.81 & 50,216 & 0.69 & 0.45 & -0.002 \\
\hline 1936 & $124,892.90$ & $89,130.29$ & $26,931.63$ & 44,767 & 0.98 & 0.70 & 0.21 \\
\hline 1937 & $115,976.10$ & $79,873.06$ & $19,874.01$ & 44,393 & 0.83 & 0.57 & 0.14 \\
\hline 1938 & $121,687.10$ & $80,217.16$ & $18,640.54$ & 49,536 & 0.72 & 0.48 & 0.11 \\
\hline 1939 & $135,812.80$ & $93,269.02$ & $29,920.89$ & 54,167 & 0.75 & 0.52 & 0.17 \\
\hline 1940 & $107,276.90$ & $61,833.98$ & $-4,521.68$ & 51,517 & 0.58 & 0.34 & -0.02 \\
\hline 1941 & $101,133.10$ & $59,647.90$ & $-11,764.46$ & 50,495 & 0.53 & 0.32 & -0.06 \\
\hline 1942 & $100,486.60$ & $60,091.00$ & $-30,949.88$ & 51,780 & 0.43 & 0.26 & -0.13 \\
\hline 1943 & $103,498.80$ & $61,346.58$ & $-34,436.89$ & 50,397 & 0.40 & 0.24 & -0.13 \\
\hline 1944 & & & & 50,640 & & & \\
\hline 1945 & $176,359.10$ & $116,201.00$ & 0 & 50,744 & 0.60 & 0.39 & 0 \\
\hline 1946 & $242,852.30$ & $169,618.00$ & $28,666.32$ & 56,525 & 0.73 & 0.51 & 0.09 \\
\hline 1947 & $285,395.90$ & $210,935.60$ & & 52,581 & 0.59 & 0.43 & \\
\hline 1948 & $285,624.40$ & $208,625.30$ & $-1,372.28$ & 53,208 & 1.43 & 1.04 & -0.01 \\
\hline 1949 & $302,473.20$ & $176,454.90$ & $-127,471.50$ & 70,781 & 1.44 & 0.84 & -0.61 \\
\hline 1950 & $401,825.60$ & $284,397.10$ & $42,200.86$ & 100,942 & 1.77 & 1.25 & 0.19 \\
\hline \multicolumn{8}{|l|}{1951} \\
\hline 1952 & $431,855.70$ & $288,159.40$ & $-15,199.55$ & 118,364 & 2.49 & 1.66 & -0.09 \\
\hline 1953 & $518,616.60$ & $352,824.50$ & $21,240.32$ & 130,981 & 2.49 & 1.69 & 0.10 \\
\hline 1954 & $631,327.40$ & & & & 2.20 & & \\
\hline 1955 & $740,092.80$ & $513,126.50$ & $100,460.50$ & 146,406 & 1.71 & 1.18 & 0.23 \\
\hline 1956 & $992,023.60$ & & & & 1.24 & & \\
\hline 1957 & $1,023,998.00$ & $745,241.50$ & $234,187.20$ & 179,610 & 1.09 & 0.79 & 0.25 \\
\hline 1958 & $1,133,155.00$ & $818,992.30$ & $177,577.90$ & 83,461 & 1.19 & 0.86 & 0.19 \\
\hline 1959 & $1,532,634.00$ & $1,196,574.00$ & $446,565.70$ & 91,417 & & & \\
\hline
\end{tabular}


Table A3: Value of prison labor, real estimates

\begin{tabular}{|c|c|c|c|c|}
\hline Year & $\begin{array}{l}\text { Real total value of } \\
\text { prison labor (PL), } \\
\text { estimate }\end{array}$ & $\begin{array}{l}\text { Real net value of } \\
\text { PL- less food costs }\end{array}$ & $\begin{array}{l}\text { Real net value of } \\
\text { PL- less prison } \\
\text { costs }\end{array}$ & $\begin{array}{l}\text { Real total value of } \\
\text { PL, reported }\end{array}$ \\
\hline 1920 & $178,498.10$ & & $55,889.37$ & \\
\hline 1921 & $160,933.50$ & $73,719.91$ & $25,485.49$ & $48,994.83$ \\
\hline 1922 & $134,452.30$ & $62,457.80$ & $15,431.08$ & $45,079.40$ \\
\hline 1923 & $107,675.80$ & $49,153.25$ & $-8,800.04$ & $47,484.70$ \\
\hline 1924 & $129,917.90$ & $82,972.27$ & $31,545.12$ & $45,744.24$ \\
\hline 1925 & $136,556.10$ & $88,395.16$ & $34,867.89$ & $44,472.38$ \\
\hline 1926 & $134,927.40$ & $79,379.46$ & $21,402.61$ & $48,298.89$ \\
\hline 1927 & $134,228.60$ & $78,527.04$ & $23,265.56$ & $48,279.13$ \\
\hline 1928 & $101,359.10$ & $49,598.37$ & $-10,280.36$ & $44,365.37$ \\
\hline 1929 & $94,333.23$ & $51,423.43$ & $6,109.08$ & $42,812.17$ \\
\hline 1930 & $80,454.55$ & $39,043.15$ & $-14,032.38$ & $42,674.24$ \\
\hline 1931 & $74,444.58$ & $36,715.22$ & $-8,060.92$ & $38,770.51$ \\
\hline 1932 & $65,938.95$ & $35,134.37$ & $-9,095.36$ & $34,842.81$ \\
\hline 1933 & $61,023.38$ & $34,944.94$ & $-1,747.74$ & $32,745.34$ \\
\hline 1934 & $64,319.20$ & $37,371.20$ & 83.53 & $33,695.84$ \\
\hline 1935 & $59,579.86$ & $39,169.19$ & -216.07 & $31,558.67$ \\
\hline 1936 & $78,983.62$ & $56,366.98$ & $17,031.86$ & $28,311.15$ \\
\hline 1937 & $76,094.96$ & $52,406.83$ & $13,039.86$ & $29,127.42$ \\
\hline 1938 & $80,804.11$ & $53,266.73$ & $12,377.91$ & $32,893.47$ \\
\hline 1939 & $92,868.03$ & $63,776.84$ & $20,459.74$ & $37,039.09$ \\
\hline 1940 & $85,651.90$ & $49,369.43$ & $-3,610.20$ & $41,132.15$ \\
\hline 1941 & $89,540.79$ & $52,810.79$ & $-10,415.97$ & $44,707.04$ \\
\hline 1942 & $95,323.28$ & $57,003.32$ & $-29,359.57$ & $49,119.37$ \\
\hline 1943 & $101,453.40$ & $60,134.20$ & $-33,756.32$ & $49,401.01$ \\
\hline 1944 & & & & $51,040.32$ \\
\hline 1945 & $182,632.70$ & $120,334.70$ & 0 & $52,549.12$ \\
\hline 1946 & $259,170.50$ & $181,015.30$ & $30,592.51$ & $60,323.12$ \\
\hline 1947 & $326,005.60$ & $240,950.10$ & & $60,062.88$ \\
\hline 1948 & $351,103.60$ & $256,452.50$ & $-1,686.87$ & $65,405.88$ \\
\hline 1949 & $382,574.80$ & $223,184.10$ & $-161,228.80$ & $89,525.38$ \\
\hline 1950 & $524,120.30$ & $370,952.70$ & $55,044.60$ & $131,663.50$ \\
\hline \multicolumn{5}{|l|}{1951} \\
\hline 1952 & $670,827.30$ & $447,615.20$ & $-23,610.36$ & $183,861.90$ \\
\hline 1953 & $830,196.60$ & $564,798.20$ & $34,001.31$ & $209,673.10$ \\
\hline 1954 & $1,030,586.00$ & & & \\
\hline 1955 & $1,260,790.00$ & $874,140.40$ & $171,140.20$ & $249,411.00$ \\
\hline 1956 & $1,776,232.00$ & & & \\
\hline 1957 & $1,898,242.00$ & $1,381,495.00$ & $434,125.80$ & $332,952.90$ \\
\hline 1958 & $2,167,774.00$ & $1,566,768.00$ & $339,714.30$ & $159,664.50$ \\
\hline 1959 & $2,944,111.00$ & $2,298,557.00$ & $857,829.70$ & $175,607.40$ \\
\hline
\end{tabular}




\section{A.4.1 Value of Prison Labor: Measuring Bias in Estimates}

Using the daily average number of prisoners might not properly capture the entire sample of prisoners whose labor was appropriated by the colonial government. Those who were charged but sent out on bail for instance would still have to commit their labor but would not be counted as being in prison.

As an alternative measure to the daily average in prison, we use the number of people committed to penal imprisonment in each year, that is the number of people who were arrested and sent to jail for one reason or another and who were expected to serve penal labor. The number of people committed to prison however does not imply that they spend the entire year there. Since the Blue Books break down sentences into 3 categories: those committed for over 2 years, those committed for between 6 months and 2 years, and those committed for less than 6 months, we weight the number of people committed to prison by the categories of their duration of stay. Specifically, we assume that those with more than two-year sentences spend 2 years in prison, those between six-month and two-year sentences spend 1 year and 3 months in prison, and those with less than six-month sentences spend

3 months in prison. Finally, we assume that imprisonment started at the beginning of the year hence 1 year in prison would run from January 1st until December 31st.

Figure A6(a) compares the daily average number in prison to our weighted average measure of people committed to prison for penal imprisonment in each year. The daily average as measured in the Blue Books tends to be much lower than our weighted average measure of those committed to prison. This is true especially in the earlier years of our sample. There however seems to be a convergence in both measures over time.

Recalculating the value of prison labor using our weighted measure of people committed to prisons shows that using the average number in prison underestimates the value of prison 
labor. At its peak the value of prison labor is more than $60 \%$ larger when using the weighted average of people committed for penal imprisonment compared to using the average number in prison as shown in Figure A6(b). The trend however remains the same with the value declining over time.
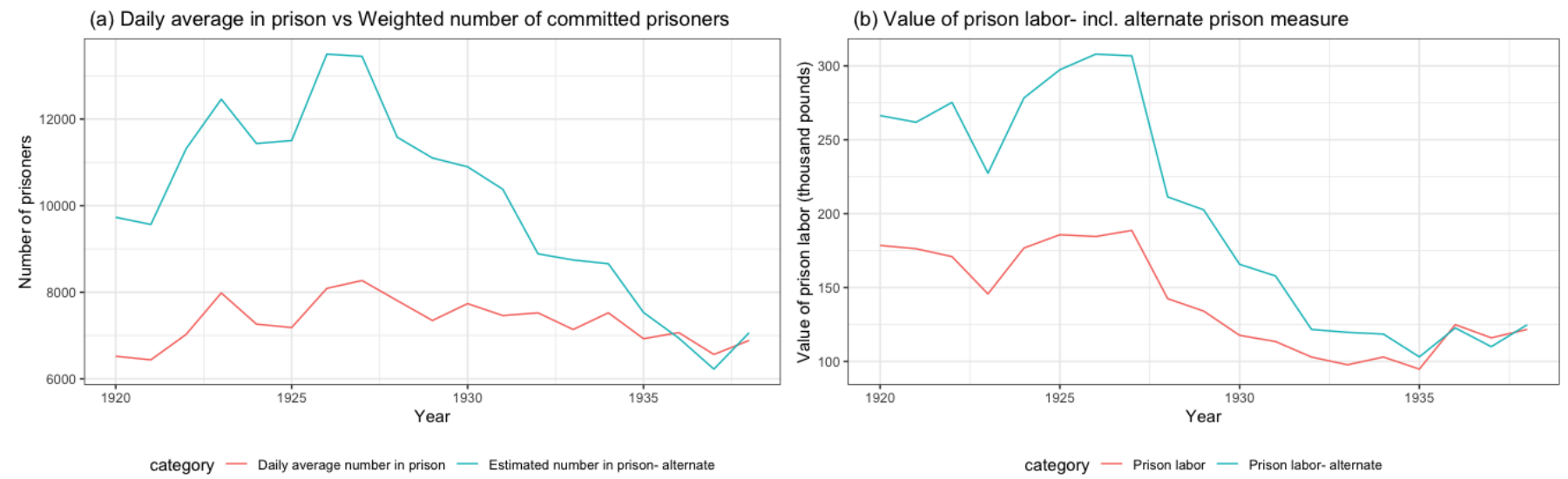

Figure A6: Alternate prison and value of labor coercion measures, 1920-1938

\section{A.5 Relationship between Colonial Imprisonment and Trust in Colonial Insti- tutions versus Interpersonal trust}

Given the rich literature on the long-term impacts of historical institutions, and coercive labor institutions in particular, on contemporary attitudes and outcomes, to explore the long-term impacts of exposure to colonial imprisonment driven primarily by economic motives around prison labor, on views of state legitimacy, we use geocoded data from all rounds of the Afrobarometer surveys for Nigeria. We use Afrobarometer surveys from all 5 rounds from 2003, 2005, 2008, 2012 and 2014. Our main outcomes of interest are, following previous literature (Nunn and Wantchekon, 2011; Lowes and Montero, 2018), respondent reported trust in institutions or individuals variables. Specifically, we use data on trust in historical legal institutions namely: trust in courts, police, and trust in tax administration and interpersonal trust: trust in neighbors, trust in relatives, trust in the president and trust in 
the local governing council member to test the hypothesis that long-term exposure to colonial imprisonment centered around prison labor reduces views of state legitimacy through lowered trust in legal institutions, with no effect on interpersonal trust.

In addition to individual level controls for age and gender and education fixed effects, to control for potential covariates that could impact both exposure to long-term colonial imprisonment and trust in legal institutions, we combine the Afrobarometer data with population density, geographic controls, disease controls and controls for precolonial and colonial institutions, with descriptions of the data and summary statistics shown in Table A4 and in the Appendix. Precolonial political institutions are proxied using Murdock's (1967) “Jurisdictional Hierarchy Beyond the Local Community Level" called the Precolonial centralization index here. The precolonial centralization index or "Jurisdictional Hierarchy Beyond the Local Community Level" variable is an index of "political complexity" that assigns a score between 0 to 4 to each ethnic region unit and describes the number of political jurisdictional hierarchies above the local community level for each unit. The score is defined as follows: 0 represents so-called "stateless societies" "lacking any form of political organization", 1 and 2 are petty and larger paramount chiefdoms, 3 and 4 are large, more organized states. The colonial institutions Nunn and Wantchekon (2011)'s total number of exported slaves in the trans Atlantic and Indian ocean slave trades from 1400-1900. Disease controls are included for malaria by using climatic suitability for malaria transmission from Adjuik et al. (1998) to address the various hypotheses in the literature on the negative impacts of malaria on African development outcomes (Gallup and Sachs, 2001) and tse tse fly suitability following Alsan (2015). Geographic controls include land suitability for agriculture, mean elevation in $\mathrm{km}$, ruggedness, and indicators for sea coast and petrol, to control for access to trade routes and mineral wealth on trust outcomes.

The results from the IV estimates for the other trust outcomes are in Table A7. The first 
stage estimates significantly predict colonial imprisonment in all specifications. The second stage estimates in Panel B of Table A7 are not significant, and hence the OLS estimates should be interpreted with caution here.

Early qualitative evidence on Nigerian citizen displeasure with the colonial prison system can be found in newspapers from the 1940s and 1950s. Nigerian journalists often publicly denounced 'human rights and unjust practices perpetrated by penal officials', including the use of corporal punishment in prisons and the lock up of political dissidents (Abiodun, $2017)^{39}$. Other historical accounts include the story of Garrick Braide, an African preacher with a large following whose anti-colonial preaching and anti-alcohol stance in 1916, angered both the British colonial government and European merchants. This lead to his arrest and sentence, after which he spent a 2 year period in prison and died shortly after, dissipating the movement but not his followers' memories, or their practice of his beliefs at a church which exists till today ${ }^{40}$ (Kalu, 1977).

\footnotetext{
${ }^{39}$ The Southerner Nigeria Defender, August 25, 1943.

${ }^{40}$ The Christ Army Church of Nigeria.
} 
Table A4: Summary Statistics: Afrobarometer Results

\begin{tabular}{|c|c|c|c|c|c|}
\hline Statistic & $\mathrm{N}$ & Mean & St. Dev. & Min & $\operatorname{Max}$ \\
\hline & \multicolumn{5}{|c|}{ Trust and Crime Outcomes } \\
\hline Trust in Courts & 11,354 & 1.21 & 0.92 & 0.00 & 3.00 \\
\hline Trust in Police & 11,486 & 0.69 & 0.87 & 0.00 & 3.00 \\
\hline Trust in Tax Admin. & 4,480 & 1.01 & 0.85 & 0.00 & 3.00 \\
\hline Trust Relatives & 4,596 & 1.97 & 1.03 & 0.00 & 3.00 \\
\hline Trust Neighbors & 4,682 & 1.37 & 1.00 & 0.00 & 3.00 \\
\hline Trust Local Gov. & 8,961 & 0.93 & 0.87 & 0.00 & 3.00 \\
\hline Fear Crime & 11,584 & 0.59 & 1.00 & 0.00 & 4.00 \\
\hline Bribery (HHS) & 8,082 & 0.27 & 0.68 & 0.00 & 3.00 \\
\hline \multirow[t]{2}{*}{ Bribery (Doc) } & 7,987 & 0.29 & 0.66 & 0.00 & 3.00 \\
\hline & \multicolumn{5}{|c|}{ Individual Controls and Fixed Effects } \\
\hline Age & 11,603 & 31.94 & 12.05 & 18.00 & 95.00 \\
\hline Age Squared & 11,603 & $1,165.29$ & 987.34 & 324.00 & $9,025.00$ \\
\hline Female & 11,654 & 0.50 & 0.50 & 0 & 1 \\
\hline \multirow[t]{2}{*}{ Education } & 11,629 & 3.27 & 1.92 & 0.00 & 7.00 \\
\hline & \multicolumn{5}{|c|}{ Geographic and Disease Controls } \\
\hline Population Density 2006 & 11,526 & 450.97 & 693.01 & 41.04 & $2,694.63$ \\
\hline Agricultural Land Suitability & 8,453 & 4.71 & 0.76 & 1.80 & 6.00 \\
\hline Malaria & 9,095 & 1.00 & 0.02 & 0.79 & 1.00 \\
\hline Ruggedness & 9,095 & 0.26 & 0.22 & 0.03 & 2.28 \\
\hline Mean Elevation & 8,332 & 248.09 & 234.70 & -0.25 & $1,284.11$ \\
\hline Sea Coast & 9,095 & 0.29 & 0.45 & 0.00 & 1.00 \\
\hline Petrol & 9,095 & 0.34 & 0.47 & 0.00 & 1.00 \\
\hline \multirow[t]{2}{*}{ Tsetse Suitability } & 7,147 & 0.91 & 0.46 & -0.78 & 1.45 \\
\hline & \multicolumn{5}{|c|}{ Precolonial and Colonial Controls } \\
\hline Precolonial Centralization & 9,095 & 1.66 & 0.78 & 0.00 & 3.00 \\
\hline \multirow[t]{2}{*}{ Slave Exports } & 9,095 & $150,841.30$ & $206,271.70$ & 0.00 & $665,966.00$ \\
\hline & \multicolumn{5}{|c|}{ Instrument } \\
\hline $\begin{array}{l}\text { Soil Suitability for Palm Oil } \\
\text { x Colonial Palm Oil Production }\end{array}$ & 11,025 & 3.09 & 7.95 & 0.00 & 32.34 \\
\hline
\end{tabular}

Notes: See text and online appendix for details. 
Table A5: Falsification Test: OLS Estimates of relationship between postcolonial imprisonment and present-day trust in historical legal Institutions versus interpersonal trust

\begin{tabular}{|c|c|c|c|c|c|c|}
\hline & \multicolumn{3}{|c|}{ Trust in Historical Legal Institutions } & \multicolumn{3}{|c|}{ Interpersonal Trust } \\
\hline & $\begin{array}{c}\text { Police } \\
(1) \\
\end{array}$ & $\begin{array}{c}\text { Courts } \\
(2) \\
\end{array}$ & $\begin{array}{l}\text { Tax } \\
(3) \\
\end{array}$ & $\begin{array}{c}\text { Neighbors } \\
(4)\end{array}$ & $\begin{array}{c}\text { Relatives } \\
(5)\end{array}$ & $\begin{array}{c}\text { Local Gov } \\
(6)\end{array}$ \\
\hline Prisoners per 100,000 pop. & $\begin{array}{l}0.000 \\
(0.001) \\
{[0.419]}\end{array}$ & $\begin{array}{l}0.001 \\
(0.001) \\
{[0.410]}\end{array}$ & $\begin{array}{c}0.000 \\
(0.001) \\
{[0.734]}\end{array}$ & $\begin{array}{c}0.003^{* *} \\
(0.001) \\
{[0.123]}\end{array}$ & $\begin{array}{c}-0.000 \\
(0.001) \\
{[0.881]}\end{array}$ & $\begin{array}{r}-0.000 \\
(0.001) \\
{[0.620]}\end{array}$ \\
\hline Mean of outcome & 0.649 & 1.121 & 0.938 & 1.345 & 1.918 & 0.875 \\
\hline Population Density & Yes & Yes & Yes & Yes & Yes & Yes \\
\hline Individual Controls & Yes & Yes & Yes & Yes & Yes & Yes \\
\hline Geographic Controls & Yes & Yes & Yes & Yes & Yes & Yes \\
\hline Disease Controls & Yes & Yes & Yes & Yes & Yes & Yes \\
\hline Precolonial and Colonial Controls & Yes & Yes & Yes & Yes & Yes & Yes \\
\hline District FE & Yes & Yes & Yes & Yes & Yes & Yes \\
\hline Year FE & Yes & Yes & Yes & Yes & Yes & Yes \\
\hline Observations & 8,792 & 8,691 & 3,243 & 3,601 & 3,438 & 6,933 \\
\hline Clusters & 36 & 36 & 36 & 35 & 36 & 36 \\
\hline
\end{tabular}

Notes: Regressions estimated by OLS. Robust standard errors in parentheses clustered by current state. Wild cluster bootstrap (by district) p-values are in brackets. The unit of observation is an individual. Prisoners per 100,000 pop. are current state level averages of prisoners per 100,000 population (1990 pop.) over 1971 to 1995. Trust variables are from the Afrobarometer samples over 2003 to 2016 and as defined in the main text. Trust outcomes are reported trust levels on a scale of $0-3$, where "Not at all"= "0", "Just a little"="1", "Somewhat"="2", "A lot"="3". All regressions use district fixed effects at the geopolitical zone level in Nigeria, year fixed effects, educational attainment fixed effects and controls for sub-district or local government area population density in 2006. Individual controls include age, age squared and gender. Geographic controls at the sub-district level include ruggedness, indicators for petroleum, seacoast and mean land suitability for agriculture and mean elevation in alternate specifications. Disease controls at the subdistrict level include malaria suitability and tse tse fly suitability in alternate specifications with results unchanged. Precolonial and colonial controls at the ethnicity-level include the level of precolonial centralization and total exports of slaves from the region during the Atlantic slave trade.

${ }^{* * *}$ Significant at the 1 percent level, ${ }^{* *}$ Significant at the 5 percent level, ${ }^{*}$ Significant at the 10 percent level. 
Table A6: OLS Estimates: Relationship between colonial and postcolonial imprisonment and present-day crime outcomes

\begin{tabular}{|c|c|c|c|c|}
\hline & \multicolumn{2}{|c|}{ Colonial Imprisonment } & \multicolumn{2}{|c|}{ Postcolonial Imprisonment } \\
\hline & $\begin{array}{c}\text { Bribery Doc } \\
(1) \\
\end{array}$ & $\begin{array}{c}\text { Fear Crime } \\
(2) \\
\end{array}$ & $\begin{array}{c}\text { Bribery Doc } \\
(3) \\
\end{array}$ & $\begin{array}{c}\text { Fear Crime } \\
(4) \\
\end{array}$ \\
\hline Prisoners per 100,000 pop. & $\begin{array}{r}-0.001 \\
(0.003) \\
{[0.644]}\end{array}$ & $\begin{array}{c}-0.002 \\
(0.005) \\
{[0.781]}\end{array}$ & $\begin{array}{c}0.001^{* *} \\
(0.000) \\
{[0.057]}\end{array}$ & $\begin{array}{c}0.001 \\
(0.001) \\
{[0.123]}\end{array}$ \\
\hline Mean of outcome & 0.225 & 0.229 & 0.571 & 0.225 \\
\hline Population Density & Yes & Yes & Yes & Yes \\
\hline Individual Controls & Yes & Yes & Yes & Yes \\
\hline Geographic Controls & Yes & Yes & Yes & Yes \\
\hline Disease Controls & Yes & Yes & Yes & Yes \\
\hline Precolonial and Colonial Controls & Yes & Yes & Yes & Yes \\
\hline District FE & Yes & Yes & Yes & Yes \\
\hline Year FE & Yes & Yes & Yes & Yes \\
\hline Observations & 5,876 & 8,420 & 6,204 & 8,875 \\
\hline Clusters & 21 & 21 & 36 & 36 \\
\hline
\end{tabular}

Notes: Regressions estimated by OLS. Robust standard errors in parentheses clustered by colonial province. Wild cluster bootstrap (by district) p-values are in brackets. The unit of observation is an individual. Prisoners per 100,000 pop. are colonial province level averages of long-term (>2 years sentence) prisoners per 100,000 population (1939 pop.) over 1920 to 1938 in columns (1) to (3), and current state level averages of prisoners per 100,000 population (1990 pop.) over 1971 to 1995 in (4) to (6). Outcome variables are from the Afrobarometer samples over 2003 to 2016 and as defined in the main text. Bribery Doc and Bribery HHS is reported frequency of respondent bribery of government official for document and household services respectively where "Never"="0", "Once or Twice"="1", "A Few Times "="2", "Often"="3". Fear Crime is how often respondent or family has feared crime in their home where "Never"="0", "Just once or twice"="1", "Several times"="2", "Many times"="3", "Always"="4". Regressions in columns (1) to (3) use district fixed effects at the state level in Nigeria, and in columns (4) to (6) use geopolitical zone fixed effects. All regressions include year fixed effects, educational attainment fixed effects and controls for sub-district or local government area population density in 2006. Individual controls include age, age squared and gender. Geographic controls at the sub-district level include mean land suitability for agriculture, ruggedness, indicators for petroleum, seacoast and mean elevation in alternate specifications. Disease controls at the sub-district level include malaria suitability and tse tse fly suitability in alternate specifications with results unchanged. Precolonial and colonial controls at the ethnicity-level include the level of precolonial centralization and total exports of slaves from the region during the Atlantic slave trade. ${ }^{* * *}$ Significant at the 1 percent level, ${ }^{* *}$ Significant at the 5 percent level, * Significant at the 10 percent level. 
Table A7: IV Estimates: Effect of relationship between colonial imprisonment and presentday trust in historical legal Institutions versus interpersonal trust

\begin{tabular}{|c|c|c|c|c|}
\hline & \multicolumn{4}{|c|}{ Panel B: Second-Stage 2SLS Estimates } \\
\hline & \multicolumn{2}{|c|}{ Trust in Historical Legal Institutions } & \multicolumn{2}{|c|}{ Interpersonal Trust } \\
\hline & Courts & Tax & Neighbors & Loc. Gov \\
\hline & $(1)$ & $(2)$ & $(3)$ & $(4)$ \\
\hline Prisoners per 100,000 pop. & $\begin{array}{c}0.013 \\
(0.016)\end{array}$ & $\begin{array}{c}0.003 \\
(0.010)\end{array}$ & $\begin{array}{c}0.010 \\
(0.054)\end{array}$ & $\begin{array}{c}0.000 \\
(0.012)\end{array}$ \\
\hline & \multicolumn{4}{|c|}{ Panel A: First-Stage Estimates } \\
\hline $\begin{array}{l}\text { Soil Suitability for Palm Oil } \\
\text { x Colonial Palm Oil Production }\end{array}$ & $\begin{array}{l}0.187^{* * *} \\
(0.039)\end{array}$ & $\begin{array}{l}0.228^{* * *} \\
(0.038)\end{array}$ & $\begin{array}{l}0.237^{* * *} \\
(0.056)\end{array}$ & $\begin{array}{l}0.178^{* * *} \\
(0.037)\end{array}$ \\
\hline F-Stat of Excluded Instrument & 22.90 & 35.29 & 17.97 & 23.70 \\
\hline Population Density & Yes & Yes & Yes & Yes \\
\hline Individual Controls & Yes & Yes & Yes & Yes \\
\hline Geographic Controls & Yes & Yes & Yes & Yes \\
\hline Disease Controls & Yes & Yes & Yes & Yes \\
\hline Precolonial and Colonial Controls & Yes & Yes & Yes & Yes \\
\hline District FE & Yes & Yes & Yes & Yes \\
\hline Year FE & Yes & Yes & Yes & Yes \\
\hline Observations & 8,256 & 3,063 & 3,415 & 6,578 \\
\hline Clusters & 21 & 21 & 21 & 21 \\
\hline
\end{tabular}

Notes: Regressions estimated by OLS. Robust standard errors in parentheses clustered by colonial province. The unit of observation is an individual. Prisoners per 100,000 pop. are averages of long-term ( $>2$ years sentence) prisoners per 100,000 population (1939 pop.) over 1920 to 1938. Trust variables are from the Afrobarometer samples over 2003 to 2016 and as defined in the main text. Trust outcomes are reported trust levels on a scale of $0-3$, where "Not at all"= "0", "Just a little"="1", "Somewhat"=" $2 "$, "A lot"="3". All regressions use district fixed effects at the current state level in Nigeria, year fixed effects, educational attainment fixed effects and controls for sub-district or local government area population density in 2006. Individual controls include age, age squared and gender. Geographic controls at the sub-district level include ruggedness, indicators for petroleum, seacoast and mean elevation in alternate specifications. Disease controls at the sub-district level include malaria suitability and tse tse fly suitability in alternate specifications with results unchanged. Precolonial and colonial controls at the ethnicity-level include the level of precolonial centralization and total exports of slaves from the region during the Atlantic slave trade. ${ }^{* * *}$ Significant at the 1 percent level, ${ }^{* *}$ Significant at the 5 percent level, ${ }^{*}$ Significant at the 10 percent level. 